\title{
5. SITE 626: STRAITS OF FLORIDA ${ }^{1}$
}

\author{
Shipboard Scientific Party²
}

\section{HOLE 626A}

Date occupied: 31 January 1985, 2205 EST (beacon drop)

Date departed: 1 February 1985, 2230 EST (cleared mud line)

Position: $25^{\circ} 36.00-08^{\prime} \mathrm{N}, 79^{\circ} 32.81^{\prime} \mathrm{W}$

Water depth (sea level; corrected $\mathrm{m}$, echo-sounding): 846.8

Water depth (rig floor; corrected $\mathrm{m}$, echo-sounding): 857.3

Bottom felt (m, drill pipe): 858.5

Total depth (m): 871.3

Penetration (m): 12.8

Number of cores: 2

Total length of cored section (m): 11.40

Total core recovered $(\mathrm{m}): 5.01$

Core recovery (\%): 44

Oldest sediment cored:

Depth sub-bottom (m): 11.40

Age: Pleistocene
Time on hole: 1 day, $25 \mathrm{~min}$

Nature: lime sand and rubble

\section{HOLE 626B}

Date occupied: 1 February 1985, 2230 EST (cleared mud line at A)

Date departed: 3 February 1985, 0715 EST

Time on hole: 1 day, $8 \mathrm{hr}, 45 \mathrm{~min}$

Position: $25^{\circ} 36.04^{\prime} \mathrm{N}, 79^{\circ} 32.81^{\prime} \mathrm{W}$

Water depth (sea level; corrected $\mathrm{m}$, echo-sounding): 848.0

Water depth (rig floor; corrected $\mathrm{m}$, echo-sounding): 858.50

Bottom felt (m, drill pipe): 858.50

Total depth (m): 1044.04

Penetration (m): 185.5

Number of cores: 5

Total length of cored section (m): 47.5

Total core recovered $(\mathrm{m}): \mathbf{1 3 . 9 6}$

Core recovery $(\%): 29.4$

Oldest sediment cored:

Depth sub-bottom (m): 185.5

Nature: unlithified grainstone and packstone

Age: early Miocene

\section{HOLE 626C}

${ }^{1}$ Austin, J. A., Jr., Schlager, W., Palmer, A. A., et al., 1986. Proc. Init. Repts. (Pt. A), ODP, 101.

2 James A. Austin Jr. (Co-Chief Scientist), Institute for Geophysics, University of Texas at Austin, Austin, TX 78751; Wolfgang Schlager (Co-Chief Scientist), Rosenstiel School of Marine and Atmospheric Sciences, Miami, FL 33149 (current address: Vrije Universiteit, Instituut v. Aardwetenschappen, Postbus 7161, 1007 MC Amsterdam, Netherlands); Amanda A. Palmer, Staff Scientist, Ocean Drilling Program, Texas A\&M University, College Station, TX 77843; Paul A. Comet, The University, Newcastle-Upon-Tyne, Newcastle, United Kingdom (current address: Core Labs Singapore, 24A-Lim Teck Boo Rd., Singapore 1953); André Droxler, Rosenstiel School of Marine and Atmospheric Sciences, Miami, FL 33149 (current address: Department of Geology, University of South Carolina, Columbia, SC 29208); Gregor Eberli, Geologisches Institut, ETH-Zentrum, Zürich, Switzerland (current address: Fisher Island Station, University of Miami, Miami, FL 33139); Eric Fourcade, Laboratoire de Stratigraphie, Université Pierre et Marie Curie, 4 Place Jussieu 75230, Paris Cedex 05, France; Raymond Freeman-Lynde, Department of Geology, University of Georgia, Athens, GA 30602; Craig S. Fulthorpe, Department of Geological Sciences, Northwestern University, Evanston, IL 60201; Gill Harwood, Department of Geology, The University, Newcastle-Upon-Tyne, NE1 7RU United Kingdom; Gerhard Kuhn, Geologisches Institut Göttingen, Federal Republic of Germany (current address: Alfred Wegener Institut für Polarforschung, Columbus Center, D-2850 Bremerhaven, West Germany); Dawn Lavoie, NORDA Code 363, Seafloor Geosciences Division, NSTL, MS 39529; Mark Leckie, Woods Hole Oceanographic Institution, Woods Hole, MA 02543 (current address: Department of Geology and Geography, University of Massachusetts, Amherst, MA 01003); Allan J. Melillo, Department of Geological Sciences, Rutgers University, New Brunswick, NJ 08903 (current address: Chevron U.S.A., New Orleans, LA 70114); Arthur Moore, Marathon Oil Company, P.O. Box 269, Littleton, CO 80160; Henry T. Mullins, Department of Geology, Syracuse University, Syracuse, NY 13210; Christian Ravenne, Institut Français du Pétrole, B.P. 311, 92506 Rueil Malmaison Cedex, France; William W. Sager, Department of Oceanography, Texas A\&M University, College Station, TX 77843; Peter Swart, Fisher Island Station, University of Miami, Miami, FL 33139 (current address: Marine Geology and Geophysics, Rosenstiel School of Marine and Atmospheric Sciences, Miami, FL 33149); Joost W. Verbeek, Dutch Geological Survey, P.O. Box 157, 2000 A.D. Haarlem, Netherlands; David K. Watkins, Department of Geology, University of Nebraska, Lincoln, NE 68588; Colin Williams, Borehole Research Group, Lamont-Doherty Geological Observatory, Palisades, NY 10964.
Date occupied: 3 February 1985, 0715 EST

Date departed: 4 February 1985, 2300 EST

Time on hole: 1 day, $15 \mathrm{hr}, 45 \mathrm{~min}$

Position: $25^{\circ} 36.02^{\prime} \mathrm{N}, 79^{\circ} 32.80^{\prime} \mathrm{W}$

Water depth (sea level; corrected $\mathrm{m}$, echo-sounding): 843.5

Water depth (rig floor; corrected m, echo-sounding): 854

Bottom felt (m, drill pipe): 855

Total depth (m): 1034.3

Penetration (m): 179.3

Number of cores: 19

Total length of cored section (m): 179.3

Total core recovered $(\mathrm{m}): 66.3$

Core recovery $(\%): 37$

Oldest sediment cored:

Depth sub-bottom (m): 179.3

Nature: sandy carbonate ooze

Age: earliest middle Miocene

\section{HOLE 626D}

Date occupied: 4 February 1985, 2300 EST

Date departed: 9 February 1985, 0800 EST

Time on hole: 4 days, $9 \mathrm{hr}$

Position: $25^{\circ} 36.02^{\prime} \mathrm{N}, 79^{\circ} 32.81^{\prime} \mathrm{W}$

Water depth (sea level; corrected m, echo-sounding): 843.5 
Water depth (rig floor; corrected m, echo-sounding): 854.0

Bottom felt (m, drill pipe): 854

Total depth (m): 1310.3

Penetration (m): 456.3

Number of cores: 28

Total length of cored section (m): 276.9

Total core recovered $(\mathrm{m}): 9.36$

Core recovery $(\%): 3.4$

Oldest sediment cored:

Depth sub-bottom (m): 446.8

Nature: limestone

Age: undated

Measured velocity $(\mathrm{km} / \mathrm{s}): 5$, Hamilton Frame

Principal results: The JOIDES Resolution occupied Site 626 (BAH-1-C) in the Straits of Florida from 31 January to 9 February 1985. Four holes were drilled, of which Holes $626 \mathrm{C}$ and $626 \mathrm{D}$ were scientifically important. Both are located at $25^{\circ} 36.02^{\prime} \mathrm{N}, 79^{\circ} 32.80 .5^{\prime} \mathrm{W}$, water depth $854 \mathrm{~m}$. Hole $626 \mathrm{C}$ was continuously cored with hydraulicpiston-core/extended-core-barrel (HPC/XCB) techniques from 0 to $179 \mathrm{~m}$ sub-bottom with $37 \%$ recovery. Hole $626 \mathrm{D}$ was washed to 179 $\mathrm{m}$ sub-bottom and continuously rotary cored from 179 to $456 \mathrm{~m}$ subbottom; recovery was $3.4 \%$. Quicksands in both holes were responsible for the low recovery and for the loss of Hole 626D.

Together, Holes $626 \mathrm{C}$ and $626 \mathrm{D}$ penetrated the following sequence: (1) 0-122 m sub-bottom; carbonate contourite sand (planktonic-foraminifer and neritic material), middle Miocene to Pleistocene in age; (2) 122-170 m sub-bottom; debris flows and turbidites, middle Miocene in age; and (3) 170-447 m sub-bottom; carbonate sand and calcarenitic limestone (all contourites), late Oligocene to middle Miocene in age.

Even though we did not reach the Cretaceous target, the site produced some significant results:

1. Several hundred meters of winnowed sand indicate that the Gulf Stream has changed little in vigor and position since the Oligocene. Throughout this time interval the Gulf Stream was able to winnow almost completely the carbonate mud and rework the turbidites with neritic material.

2. Middle Miocene debris flows and turbidites are coeval with similar deposits in the Blake Basin (DSDP Sites 391 and 534), suggesting a common tectonic or environmental trigger.

3. Diagenesis in the carbonate deposits is less advanced than in coeval deep-sea carbonates. This surprising trend remains currently unexplained.

4. Borehole stratigraphy provides adequate ties with seismic reflectors of the site surveys.

5. Comparison of Site 626 with the Great Isaac 1 well on Great Bahama Bank provides strong arguments in favor of the "megabank" hypothesis, which proposes that Florida and the Bahama Banks formed one large, unsegmented platform until mid-Cretaceous time. Oligocene-Miocene facies in the two wells are similar, and time lines between them nearly horizontal. The present relief between the two areas apparently developed during the late MiocenePliocene, when the margin of Great Bahama Bank prograded westward to its current position. Mid-Miocene and older rocks at Sites 626 and Great Isaac seem to be connected without significant vertical offset. Therefore, by inference, the untested target reflector at Site 626 corresponds to the top of mid-Cretaceous platform carbonates drilled at Great Isaac.

\section{BACKGROUND AND OBJECTIVES}

\section{Background}

Operations at Site 626 represented the first attempt to drill on the Bahama Platform since 1971. Until Leg 101, only five other deep stratigraphic tests had ever been conducted. Of these, four were efforts by the oil industry: Andros 1, to a total depth of $4446 \mathrm{~m}$, by Chevron-Gulf in 1947; Cay Sal IV-1, $5763 \mathrm{~m}$, by Chevron-Gulf in 1959; Long Island 1, $5351 \mathrm{~m}$, by Chevron-
Gulf in 1970; and Great Isaac 1, $5440 \mathrm{~m}$, by Chevron in 1971 (Paulus, 1972; Tator and Hatfield, 1975). Only the Great Isaac 1 well penetrated beneath the carbonate section to sample Upper Triassic(?) volcaniclastics. All of the others bottomed in Upper Jurassic-Lower Cretaceous carbonates or anhydrite. The fifth borehole is Deep Sea Drilling Project (DSDP) Site 98 near the axis of the Northeast Providence Channel. In 1970, DSDP Site 98 sampled approximately $350 \mathrm{~m}$ of a deep-water-carbonate section before terminating in calciturbidites of early Campanian age (Hollister, Ewing, et al., 1972).

Bahamian stratigraphy has been further developed by means of dredging and submersible sampling, but these efforts have been confined primarily to the precipitous Bahama Escarpment, which forms the northeastern limit of the carbonate province and its modern boundary with the western North Atlantic Basin. Examples of these studies are the detailed section of Lower Cretaceous-Cenomanian platform carbonates overlain by Maestrichtian and middle Eocene pelagic limestones measured by the DSRV Alvin north of Cat Island (Freeman-Lynde et al., 1981), and the detailed correlation of dredged Valanginian-Cenomanian deep-water chalks and limestones with a crossing multichannel seismic-reflection line in the Samana Reentrant of the Bahama Platform south of San Salvador (Schlager, Austin, et al., 1984).

Apart from the nature of the basement, the most intriguing question in Bahamian geology is the origin of the present pattern of banks and basins. Some viewed these features as extremely long-lived and rooted in the structure (Talwani et al., 1960; Mullins and Lynts, 1977) or topography (Hess in Talwani et al., 1960) of the Triassic-Lias rift system of this continental margin. Others proposed that banks and basins formed much later on top of a large carbonate bank that stretched from the eastern Bahamas to the Gulf of Mexico and northern Cuba (Paulus, 1972; Meyerhoff and Hatten, 1974; Sheridan, 1974; Schlager and Ginsburg, 1981; Sheridan et al., 1981).

Two predominant hypotheses have emerged as a result of these studies (Fig. 1). The graben hypothesis, as advanced by Mullins and Lynts (1977), postulates that the present topographic configuration of the Bahamas reflects underlying horsts and grabens developed during the separation of Africa and North America in the Late Triassic-Early Jurassic. These authors used their concept to explain both the apparent overlap of the Bahamas with Africa in plate reconstructions of the North Atlantic and the arkosic "graben-fill" recovered at the bottom of the Great Isaac 1 well. The broad implication of the graben hypothesis is that deep-water-carbonate facies should consistently characterize the stratigraphic successions beneath troughs, while shallower water facies persist beneath the intervening banks. While available well control on the banks supports the notion that the present banktrough configuration has been generally stable since the Late Cretaceous (Schlager and Ginsburg, 1981), the Great Isaac 1 well indicates tens of kilometers of progradation of the northwestern part of Great Bahama Bank since the Miocene (see "Summary and Conclusions," this chapter). This suggests migration of bank edges over time regardless of the nature of underlying crustal structure.

The megabank hypothesis proposes shallow roots for the bank-basin pattern. Sheridan et al. (1981) used multifold seismic-reflection profiles and sonobuoys to identify a pronounced discontinuity in compressional wave velocity (from 4.2 to 5.2 $\mathrm{km} / \mathrm{s}$ ) beneath the Straits of Florida and the Northwest Providence Channel (Fig. 2). By extrapolation of well control both in Florida and on the Great Bahama Bank, Sheridan and his coauthors correlated this acoustic horizon with the boundary between Aptian-Albian shallow-water limestones and Cenomanian and younger pelagic-hemipelagic carbonates, suggesting a midCretaceous drowning of a larger, previously homogeneous car- 

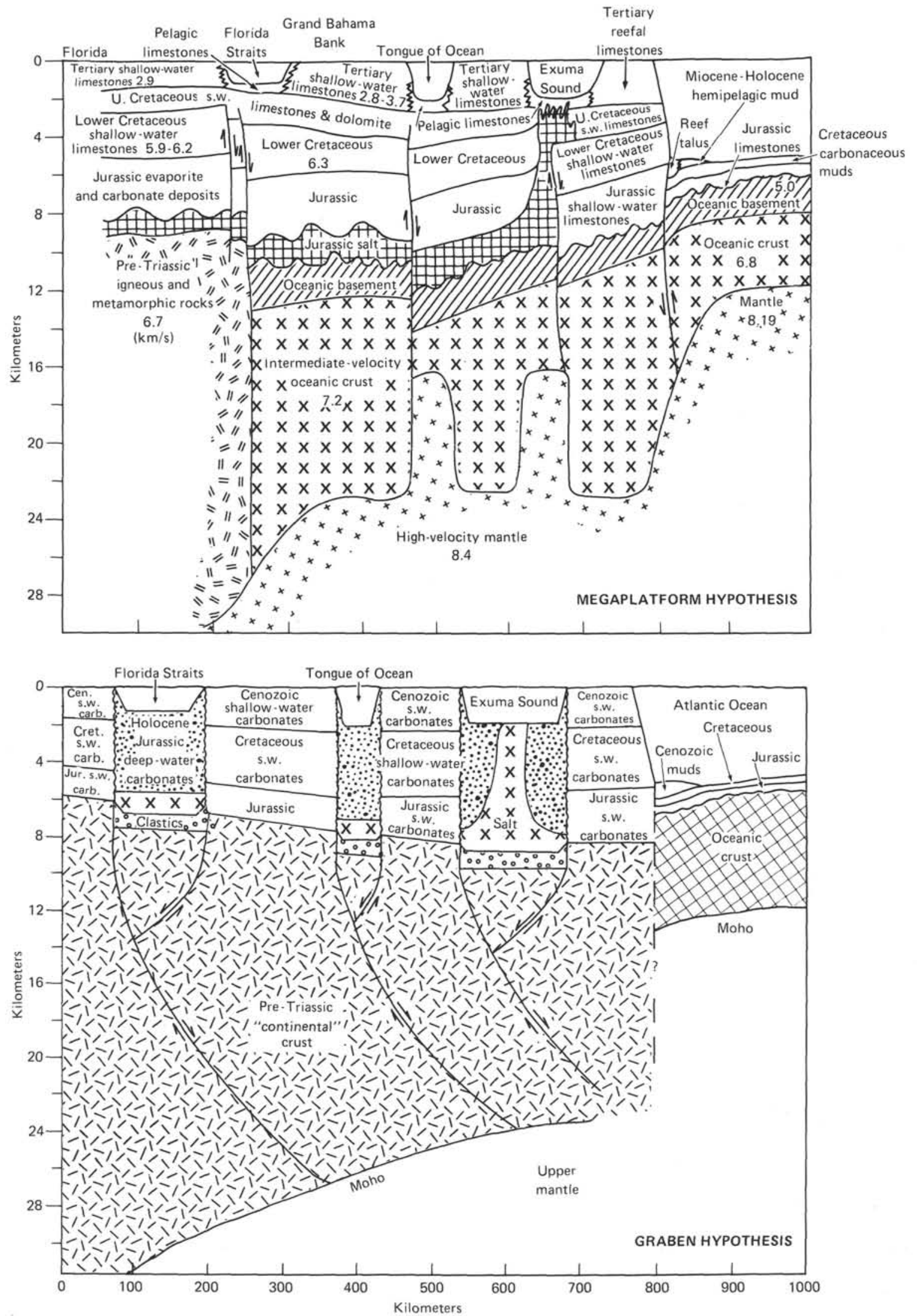

Figure 1. The two currently favored hypotheses concerning the origin and evolution of the Bahamas (after Sheridan et al., 1981; Mullins and Lynts, 1977). 
NW

SE

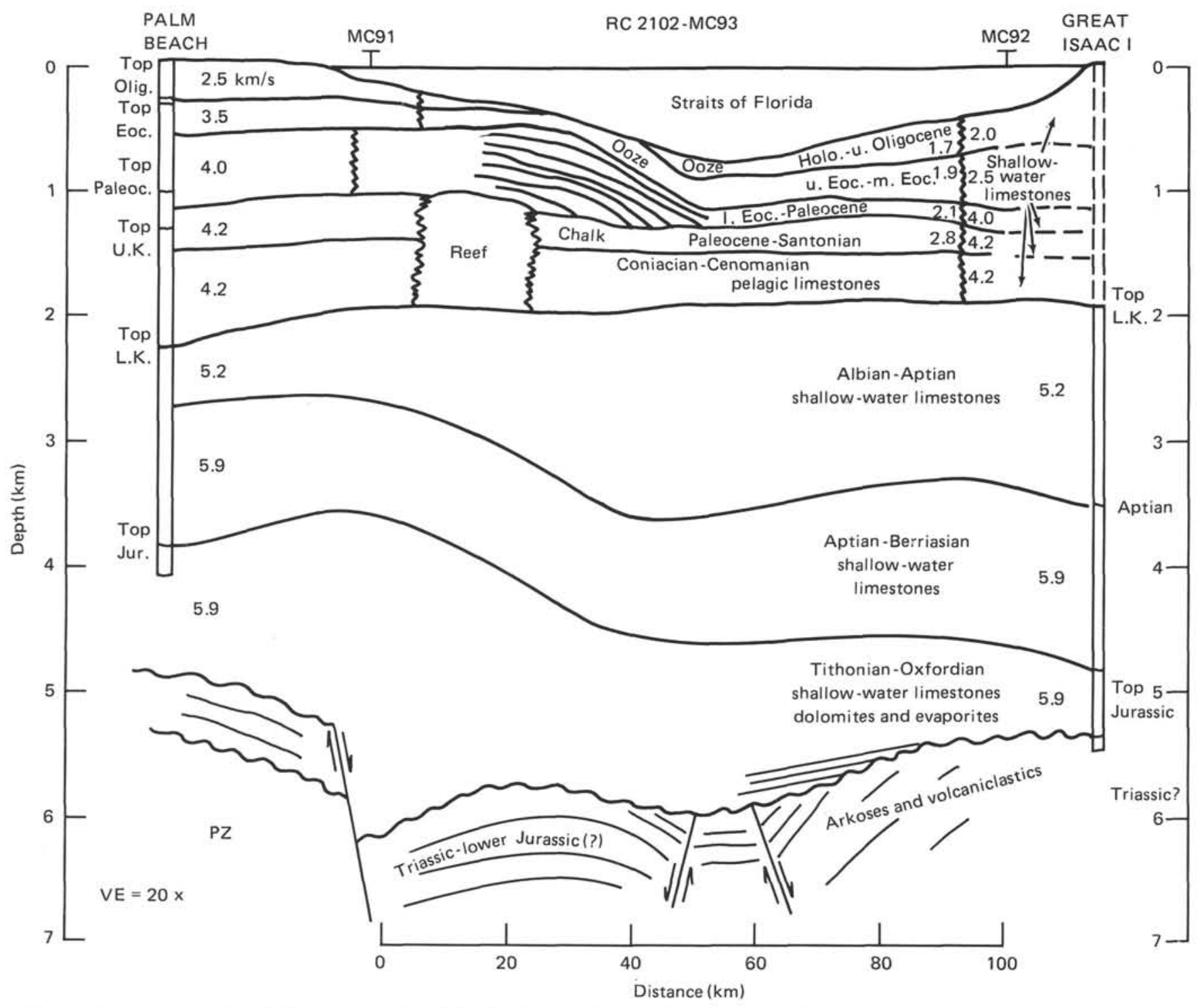

Figure 2. Seismic line RC2102-MC93 in the Straits of Florida from Sheridan et al. (1981), illustrating the acoustic horizon interpreted as the boundary between Aptian-Albian shallow-water limestones and Cenomanian and younger pelagic-hemipelagic carbonates.

bonate platform or "megabank." Using stratigraphic evidence from both the Bahamas and Cuba, Meyerhoff and Hatten (1974) and Schlager and Ginsburg (1981) also concluded that partial drowning of an Early Cretaceous megabank was responsible for the present pattern of Bahamian platforms and troughs.

In contrast to the graben hypothesis, the megabank hypothesis predicts that platform facies should underlie both highs and lows below the unconformity created by the drowning event(s). At the same time, this second hypothesis relates initiation of modern Bahamian relief to a global crisis of carbonate platforms in the mid-Cretaceous. The postulated timing also correlates neatly with a major seismic unconformity in the deep Gulf of Mexico termed the mid-Cretaceous unconformity (MCU) by Buffler et al. (1981). The MCU signals a major stratigraphic turning point that coincides with the drowning of carbonate platforms rimming the Gulf (Schlager et al., 1984). The MCU was interpreted by Buffler (1984) as a response to a rapid fall in Cenomanian sea level (the postulated $98 \mathrm{Ma}$ lowstand of Vail et al., 1977), with consequent erosion, followed by a sea-level rise and associated initiation of deep-water clastic deposition. It remains undetermined whether the sequence boundary is shaped primarily by erosion during a lowstand of sea level or by platform drowning and backstepping during a sea-level rise.

In an attempt to provide additional seismic data needed for three-dimensional structural control prior to drilling, both regional and site-specific geophysical surveys were conducted in several areas of the Bahamas by a consortium of universities led by the University of Texas Institute for Geophysics. High-resolution, 12-fold water-gun reflection and sonobuoy refraction profiles were collected. The survey in the Straits of Florida consisted of a 250-nautical-mile (n. mi) grid (see "Operations Summary," this chapter). These profiles were processed and interpreted in the manner of Vail et al. (1977), and both the pronounced velocity discontinuity of Sheridan et al. (1981) and a number of younger seismic-sequence boundaries were identified and mapped (Fig. 3).

Site 626 (BAH-1-C) lies approximately $61 \mathrm{~km}$ east-southeast of Miami, Florida, and $28 \mathrm{~km}$ west-southwest of the island of 


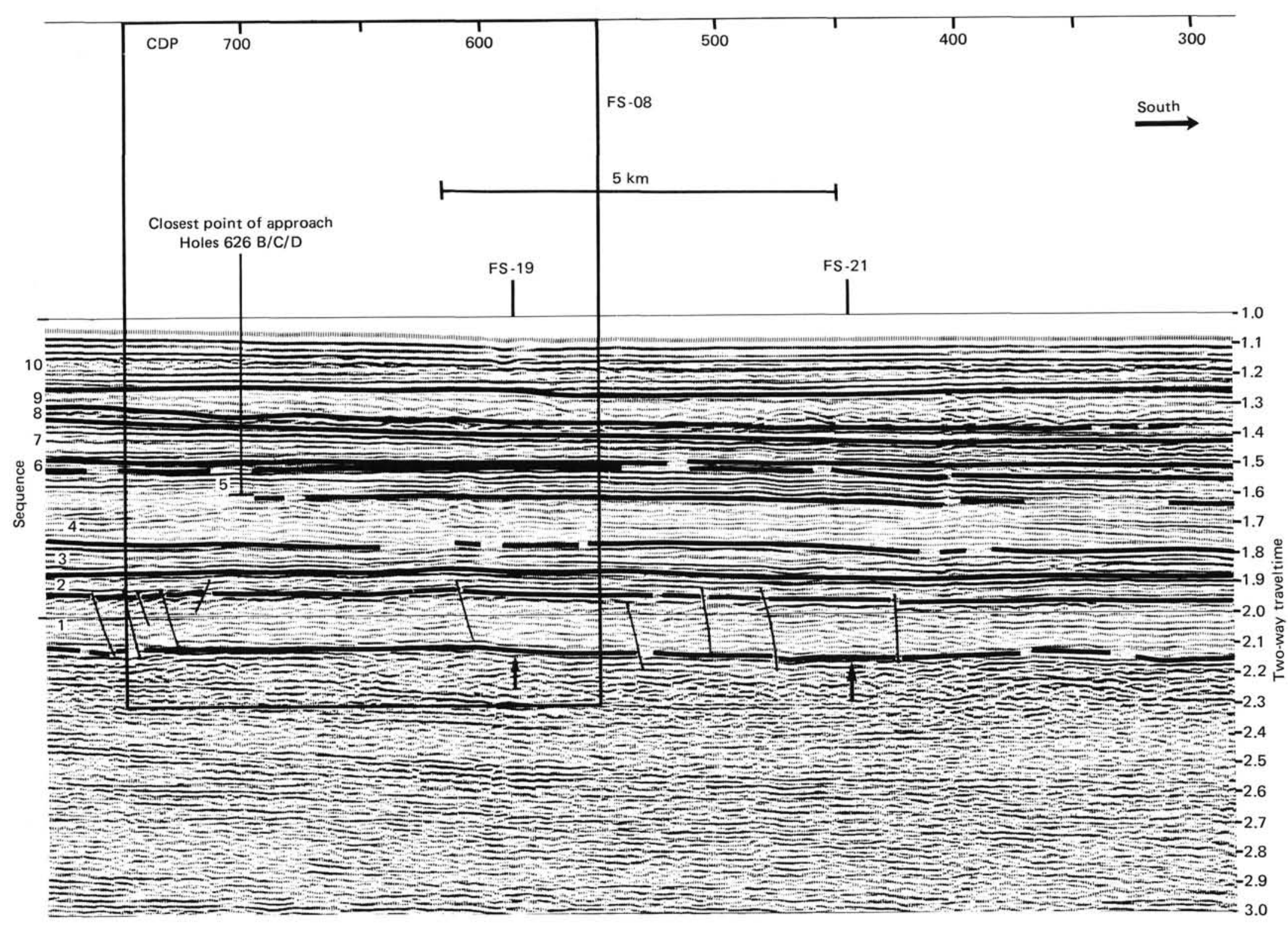

Figure 3. Interpreted copy of survey line FS-08. The target horizon is indicated by arrows. This is the pronounced velocity discontinuity of Sheridan et al. (1981). Younger sequence boundaries and faults are also indicated. Box indicates portion of FS-08 detailed in Figure 19. 
Bimini in the Bahamas (Fig. 4). This location is just east of the axis of the Straits of Florida and the present thalweg of the Gulf Stream. On $3.5-\mathrm{kHz}$ profiles collected during the site surveys, bottom returns in the vicinity of the site are reverberant, of high amplitude, and characterized by up to $7 \mathrm{~m}$ of local relief. Water depths in this part of the Straits generally exceed $800 \mathrm{~m}$.

\section{Objectives}

Based on analysis of the site-survey results in the Straits, the depth to the velocity discontinuity and sequence boundary of Sheridan et al. (1981) was estimated to be approximately $1200 \mathrm{~m}$ sub-bottom at Site 626. Recovery of a continuous section above that surface, and sampling of it, were considered to be important in providing answers to the following scientific questions:

1. What is the nature of the basal discontinuity? If this discontinuity indeed marks the transition downward from deepwater to shallow-water carbonate facies, the megaplatform hypothesis is proved for the Straits of Florida and, by seismic cor- relation, for the Northwest Providence Channel. If not, the graben hypothesis remains viable, at least where subsequent bank progradation cannot be proved.

2. What is the depositional record of the Gulf Stream? Did it or its predecessor(s) play a role in the postulated mid-Cretaceous drowning of this carbonate platform? How does it affect the vertical and lateral migration of facies patterns through time?

3. How do the ages of seismic-sequence boundaries identified beneath the Straits compare with the global fluctuations in relative sea levels postulated by Vail et al. (1977)?

4. What is the role of Cuba in supplying clastic sediments to this site, particularly during the Late Cretaceous-Paleogene collision of the Cuban island arc with the Florida-Bahamas carbonate province?

5. Finally, can Straits of Florida stratigraphy be successfully tied to better dated Mesozoic-Cenozoic stratigraphic successions in the deep Gulf of Mexico Basin, on the Blake Plateau, and farther northward along the east coast of the United States and Canada?

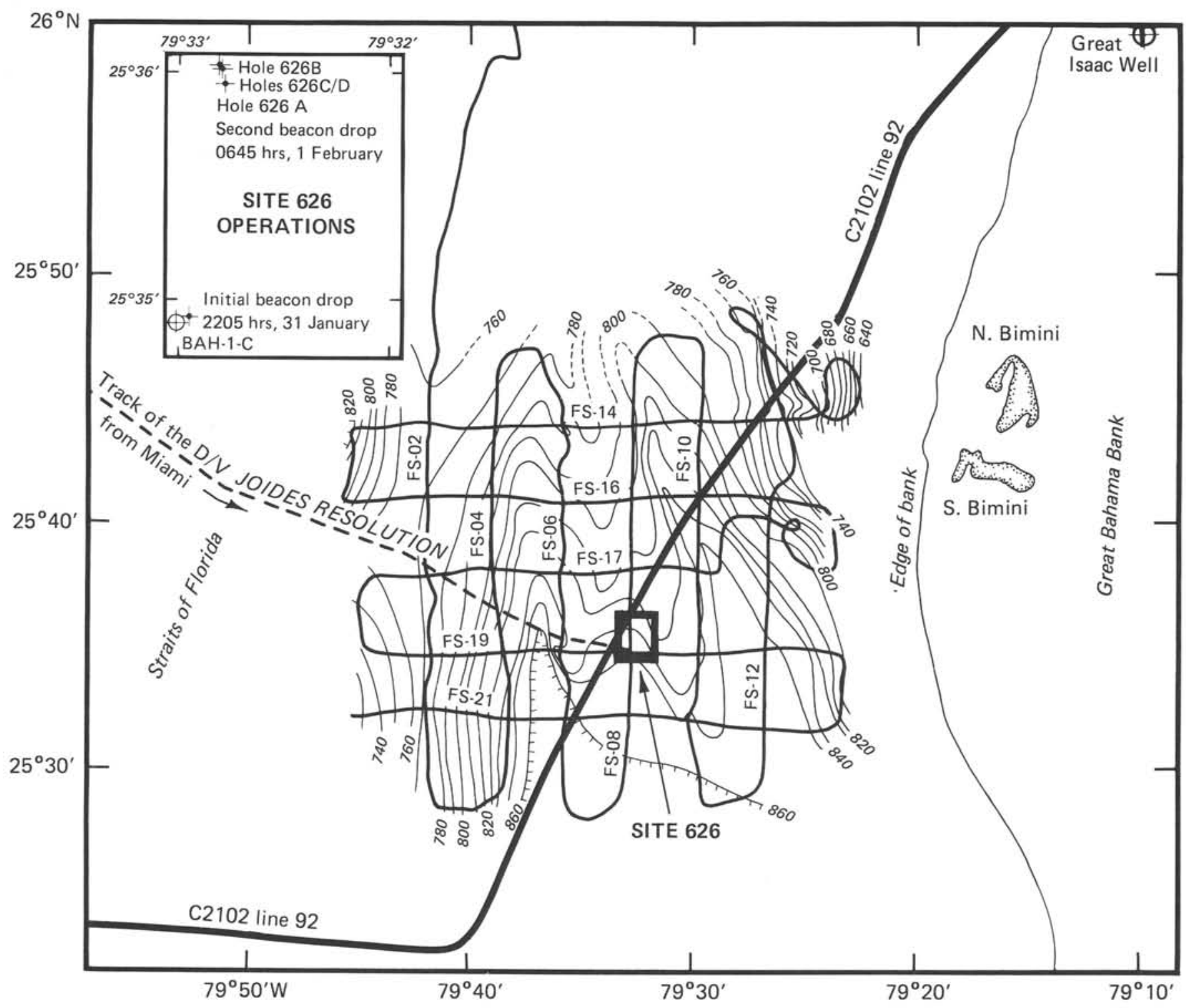

Figure 4. Trackline map (bathymetry shown in meters) for the site-specific survey in the Straits of Florida region (SF). $C$ denotes multichannel seismic lines reported by Sheridan et al. (1981). Seismic line 1, ODP Leg 101, is shown by the dashed line. Detail of Site 626 operations appears in inset, upper left. 


\section{OPERATIONS SUMMARY}

\section{Introduction}

During the shakedown cruise of the JOIDES Resolution, ODP Leg 100 (22-26 January 1985), attempts were made to drop a reentry cone at designated sites BAH-1-A, BAH-1-B, and BAH-1-C within the Straits of Florida survey grid (Fig. 4). BAH-1-A and BAH-1-B were considered to be the optimum targets for drilling in the Straits. Unfortunately, efforts at both sites were unsuccessful as a result of excessive drill-string vibration caused by Gulf Stream currents. BAH-1-C was then chosen as the best available alternative because it was out of the thalweg of the Gulf Stream, despite indications on $3.5-\mathrm{kHz}$ records of a hard, reverberent bottom there which might make spudding in difficult. Unfortunately, even at BAH-1-C, surface currents proved too strong for deployment of a reentry cone. Consequently, plans for Leg 101 were changed to accommodate a single-bit attempt at that location.

\section{Site 626}

Leg 101, the inaugural leg of the new Ocean Drilling Program (ODP), began at $1635 \mathrm{hr}$ (all times given in this report will be Eastern Standard Time) on 31 January 1985, when the JOIDES Resolution departed the dock in Miami, Florida, for Site 626 (BAH-1-C) in the Straits of Florida. Geophysical acquisition began approximately an hour later. Data from single-channel seismic-reflection profiling (in both analog and digital formats; see "Underway Geophysics" chapter, this volume), using a Teledyne $100-\mathrm{m}$ streamer and an SSI $400-$ in. $^{3}$ water gun, $3.5-\mathrm{kHz}$ and $12-\mathrm{kHz}$ precision depth recordings, and continuous magnetometer measurements, were collected on a course of $112^{\circ}$ at speeds ranging from 5 to $8 \mathrm{kt}$. The magnetometer soon failed completely for reasons unknown. Occasional intermittent firing of the water gun was ascribed to a faulty trigger pulse from the lab, which was soon corrected. By $2130 \mathrm{hr}$, the ship was approaching BAH-1-C from the west-northwest (Fig. 4). A Datasonics 24-day beacon was deployed at $2205 \mathrm{hr}$ on 31 January at $25^{\circ} 34.92^{\prime} \mathrm{N}, 79^{\circ} 32.95^{\prime} \mathrm{W}$, less than $0.1 \mathrm{n}$. mi northeast of the designated site location (the intersection of site-survey lines FS-08 and FS-19; Fig. 4). Figure 5 shows a part of the digital single-channel seismic line recorded on our initial approach to Site 626.

After retrieving the seismic gear, a short delay was encountered in turning back to the site because of a problem with a bow thruster, but ranging on the beacon began shortly before midnight, 31 January. Bottom returns using the $3.5-\mathrm{kHz}$ system were of high amplitude and composed of small diffractions, suggesting local relief of approximately $1 \mathrm{~m}$. The water depth was $847 \mathrm{~m}$ (corrected from a $12-\mathrm{kHz}$ reading of $840 \mathrm{~m}$ at a hullmounted transducer $7 \mathrm{~m}$ below the water line).

Within the first hour, signals from the beacon to the Resolution's Honeywell dynamic-positioning system became erratic. As a backup, a "taut wire" was deployed off the ship's starboard side. In shallow water, such a device provides a positioning capability by allowing monitoring of wire angles. However, because of the presence of a 1.5-2.0-kt Gulf Stream surface current, this method of ranging was marginally effective. Nonetheless, by $0415 \mathrm{hr}$ on 1 February, the decision was made to run in hole (RIH). Approximately $560 \mathrm{~m}$ of pipe was out when the signal for the ranging beacon was lost at $0630 \mathrm{hr}$. An immediate decision was made to launch a second beacon on a different frequency, which was accomplished at $0645 \mathrm{hr}$ at $25^{\circ} 35.95^{\prime} \mathrm{N}$, $79^{\circ} 32.78^{\prime} \mathrm{W}$. By this time, the ship had drifted approximately $1.0 \mathrm{n}$. mi northeast of the original site location but only $0.25 \mathrm{n}$. $\mathrm{mi}$ of the northward continuation of site-survey line FS-08 (Fig. 4 , inset). After a short period of ranging on the new beacon, the rest of the pipe was RIH. The bottom-hole assembly (BHA) touched bottom at $858.5 \mathrm{~m}$ below the dual elevator stool, in excellent agreement with the $857.3 \mathrm{~m}$ predicted by the $12-\mathrm{kHz}$ data.

The first "mud-line" rotary core of Hole 626A was recovered at $1255 \mathrm{hr}$ on 1 February and consisted of $1.44 \mathrm{~m}$ of lime sand and rubble. A second rotary core recovered $3.57 \mathrm{~m}$ of Pleistocene skeletal lime sand. However, while washing at $15 \mathrm{~m}$ subbottom, the core barrel jammed and the bit plugged. This core barrel was subsequently retrieved using a second barrel, and circulation was restored. Unfortunately, the signal from the second beacon was lost at approximately $2015 \mathrm{hr}$ during continued washing, forcing a decision to pull out of the hole $(\mathrm{POOH})$ and terminate Hole 626A. Consequently, the bit had to be successfully cleared above the mud line to a depth of $680 \mathrm{~m}$. The consensus of the shipboard engineering staff was that either the beacons were defective or they were being tilted by bottom currents, making their usefulness for surface positioning in the Straits suspect.

The dilemma was resolved as the Resolution drifted downcurrent (north-northwest) approximately $360 \mathrm{~m}$ and reacquired the signal of the second beacon, proving that this beacon was leaning with the current at approximately a $14^{\circ}$ angle. Ranging at the downstream location $\left(25^{\circ} 36.04^{\prime} \mathrm{N}, 79^{\circ} 32.81^{\prime} \mathrm{W}\right.$; Fig. 4, inset) was successful, and pipe was RIH for Hole 626B starting at $0115 \mathrm{hr}, 2$ February.

After encountering the mud line at $858.5 \mathrm{~m}$ below the rig floor, the string was successfully washed in to a sub-bottom depth of $80.3 \mathrm{~m}$, where the bit became partly plugged with sediment. In order to restore circulation, the core barrel was retrieved at $1055 \mathrm{hr}$. The first wash core of Hole 626B recovered $4.1 \mathrm{~m}$ of lower Pliocene glauconitic foraminifer-nannofossil sand and lime rubble. Throughout the rest of 2 February, washing and coring continued intermittently. Hole conditions continued to be unstable as a result of unconsolidated sands, and drilling mud was frequently used during coring operations to condition the hole. The oldest sediments recovered down to $185.5 \mathrm{~m}$ sub-bottom were latest early Miocene to middle Miocene. At that depth, in the process of trying to retrieve a stuck core barrel, the drill string was over-torqued while reaming and washing to the bottom of the hole. Before any braking could be applied, backlash caused the string to back off, resulting in the loss of the BHA and 19 joints (approximately $170 \mathrm{~m}$ ) of pipe. Subsequent attempts to screw the two ends of the string together proved futile.

All remaining pipe was $\mathrm{POOH}$ at Hole $626 \mathrm{~B}$ by $0715 \mathrm{hr}, 3$ February. The decision was made to offset slightly and to use HPC/XCB techniques to sample the section washed through at Hole $626 \mathrm{~B}$ as Hole $626 \mathrm{C}$. By noon, after making up a new BHA, pipe was RIH at the new location $\left(25^{\circ} 36.02^{\prime} \mathrm{N}, 79^{\circ} 32.80^{\prime} \mathrm{W}\right.$; Fig. 4, inset). The mud line was encountered at $855 \mathrm{~m}$ below the rig floor, and the first XCB core, recovered at $1645 \mathrm{hr}$, contained calcareous sand and rubble. Cores continued to come up at the rate of $1 / 1.5 \mathrm{hr}$ for the next $18 \mathrm{hr}$ down to a sub-bottom depth of $112.1 \mathrm{~m}$. At that point, a switch was made to the HPC for core 13 in an attempt to improve recovery, which was running at only $11 \%$ for the XCB. Seven HPC cores were recovered down to a sub-bottom depth of $179.3 \mathrm{~m}$, with average recovery of $79.8 \%$. The predominant lithology was bioclastic foraminiferal sand, and the oldest material recovered was early Miocene. At $2300 \mathrm{hr}$ on 4 February, Hole $626 \mathrm{C}$ was terminated in order to begin Hole $626 \mathrm{D}$, a single-bit rotary penetration to the original target horizon identified by the site surveys, essentially a repeat of the prematurely terminated Hole 626B. The Hole 626D location $\left(25^{\circ} 36.02^{\prime} \mathrm{N}, 79^{\circ} 32.81^{\prime} \mathrm{W}\right.$; Fig. 4, inset) represented a minimum offset from Hole $626 \mathrm{C}$ (less than $50 \mathrm{~m}$ ).

At $0845 \mathrm{hr}$ on 5 February, pipe was RIH at Hole 626D. The mud line was encountered at $854 \mathrm{~m}$ below the rig floor, and the section was washed continuously down to a depth of $179.4 \mathrm{~m}$ 


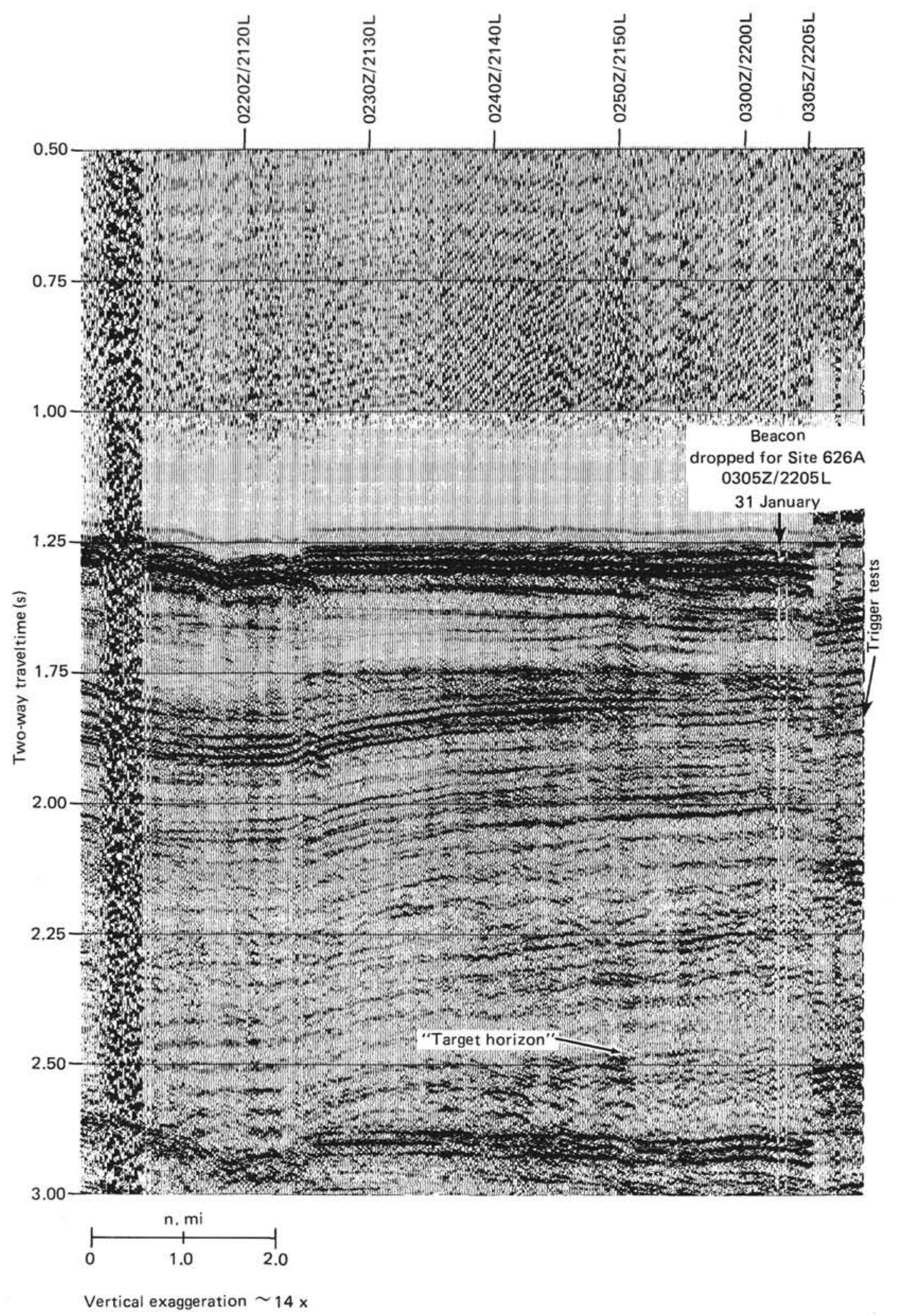

Figure 5. Part of ODP Leg 101 Line 1, approaching Site 626. The data are digital, samples at $1 \mathrm{~ms}$. Sound source was a 400 -in. ${ }^{3}$ water gun fired every $12 \mathrm{~s}$. Receiver was $100 \mathrm{~m}$ in length, separated from the JOIDES Resolution by a 500 -m leader. 
sub-bottom. The first rotary core was recovered late on 6 February, containing $1.4 \mathrm{~m}$ of a partly cemented foraminifer-nannofossil sand with some intergranular fillings of asphalt, which the organic geochemists determined to be completely oxidized and perhaps detrital. Rotary coring continued throughout 6 and 7 February, with both poor recovery (less than 10\%) and continuing poor hole conditions as a result of quicksand, necessitating repeated hole conditioning with drilling mud. The oldest sediments recovered, at $437.3 \mathrm{~m}$ sub-bottom, were early Oligocene (Core 626D-27R). Core 626D-28R, CC recovered fragments of an undated, well-cemented foraminiferal grainstone. In the process of trying to retrieve Core $626 \mathrm{D}-29 \mathrm{R}$ from approximately $456 \mathrm{~m}$ sub-bottom late in the evening of 7 February, both the core barrel and the string became stuck. Apparently sand had penetrated upward around the core barrel, effectively burying it inside the drill pipe. Repeated attempts to reach it using a second core barrel equipped with a hard-formation catcher were unsuccessful, and circulation could not be restored. At $0700 \mathrm{hr}$ on 8 February, the decision was reluctantly made to sever the pipe at $1201.77 \mathrm{~m}$ below the rig floor at the top of the third drill collar. No logging personnel from Schlumberger were as yet aboard, so a decision about running logs either below the severed pipe or within the string was postponed.

During the afternoon of 8 February, the drill collar was successfully severed by the first charge. However, the pipe remained stuck, so another charge was prepared for detonation at 1106.21 $\mathrm{m}$ below the rig floor. In the meantime, a neutron log was run in the hole inside the pipe by a Schlumberger engineer, who had joined the vessel by helicopter. After the logging was completed, the second charge failed to explode, and a third was prepared for detonation at the same depth. That, too, failed. Finally, at $0500 \mathrm{hr}$ on 9 February, a fourth charge succeeded in severing the string at $1048.69 \mathrm{~m}$ below the rig floor. The remaining pipe was POOH successfully by $0800 \mathrm{hr}$, and the Resolution departed Hole 626D immediately thereafter for Site BAH-9-A on the northern slope of Little Bahama Bank.

The coring summary for Site 626 appears in Table 1.

\section{SEDIMENTOLOGY}

\section{Introduction}

Four holes were drilled at Site 626 . Hole 626A penetrated $12.8 \mathrm{~m}$ sub-bottom into sediments with $4.9 \mathrm{~m}$ of recovery $(38 \%)$; Hole 626B penetrated $185.5 \mathrm{~m}$ sub-bottom with $14.03 \mathrm{~m}$ of recovery $(8 \%)$; Hole $626 \mathrm{C}$ penetrated $179.3 \mathrm{~m}$ sub-bottom with $66.3 \mathrm{~m}$ of recovery $(37 \%)$; and Hole $626 \mathrm{D}$ penetrated $446.8 \mathrm{~m}$ sub-bottom, cored from 179.6 to $446.8 \mathrm{~m}$ sub-bottom, with 9.36 $\mathrm{m}$ of recovery $(3.5 \%)$.

Sediments recovered are dominantly unlithified, muddy to clean calcareous sands and gravels (packstones, grainstones, floatstones, and rudstones), light gray $(2.5 \mathrm{Y} 8 / 2)$ to white $(2.5 \mathrm{Y}$ $7 / 2$ ), containing about $1 \%-5 \%$ glauconite. Three dominant kinds of grains, or compositional end-members, compose the sand and gravel fraction of these sediments: planktonic foraminifers and pteropods, skeletal fragments, and clasts. Skeletal fragments include ahermatypic corals, red algae, green algae, echinoderm spines and plates, bivalves, gastropods, pteropods, and benthic foraminifers and are principally of shallow-water origin. Clasts are dominantly lithified skeletal packstones and grainstones. Skeletal fragments in the clasts are principally of shallow-water origin. Proportions of different grain types vary in these sediments, and so in the sediment descriptions below the order of the three compositional end-members has no significance.
Based principally on the continuous coring in Holes $626 \mathrm{C}$ and $626 \mathrm{D}$, the section sampled at Site 626 is divided into three lithologic units:

\section{Unit I (0-121.7 m sub-bottom; Cores 626A-1R and 626A-2R; Cores 626C-1X to 626C-13H)}

Unit I occurs from 0 to $121.7 \mathrm{~m}$ sub-bottom in Hole $626 \mathrm{C}$ and consists dominantly of unlithified, glauconitic foraminiferal-skeletal grainstone and packstone, with grain size ranging from medium to coarse sand.

Coarse gravels (clast-skeletal rudstone) were recovered at the seafloor at both Holes 626A and 626C (Fig. 6). We designate these gravels as Subunit IA. These gravels also occurred as downhole contamination in the form of a graded bed at the top of Core $626 \mathrm{C}-13 \mathrm{H}$. The coarse nature of these deposits is probably the result of winnowing by the Florida Current, which has a present-day average velocity at the bottom in the vicinity of Hole $626 \mathrm{~A}$ of about $30 \mathrm{~cm} / \mathrm{s}$ (Brooks, 1979). All of Core 626A-2R and the base of Core $626 \mathrm{C}-3 \mathrm{X}$ contain clasts, in addition to foraminifers and skeletal fragments characteristic of the remainder of this unit. In Hole 626B, Unit I is represented by $4.1 \mathrm{~m}$ of unlithified, glauconitic foraminiferal-skeletal grainstone, with grain size ranging from fine to coarse sand, recovered in Core 626B-1W $(0-80.2 \mathrm{~m}$ sub-bottom), and a few fragments (about $5 \mathrm{~cm}$ ) of foraminiferal chalk found in the core catcher of Core $626 \mathrm{~B}-2 \mathrm{~W}$ (80.3-128.1 m sub-bottom). Unlithified foraminiferal packstone was recovered in several cores in Hole $626 \mathrm{C}$. Unit I also contains a volcanic-ash layer (dark grayish brown, $2.5 \mathrm{Y} 4 / 2$ ) in the interval between 54.3 and $63.9 \mathrm{~m}$ sub-bottom (see Core 626C-7X). The alternation of foraminiferal-skeletal grainstones and packstones in Unit I implies fluctuations in intensity of winnowing by, and therefore changes in velocity of, the Florida Current during deposition of Unit I.

\section{Unit II (121.7-169.6 m sub-bottom; Core 626B-4R;

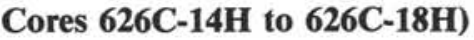

In Hole $626 \mathrm{C}$, Unit II consists of at least three debris flows separated by lithologies similar to those in Unit I and by lithified layers. Unit II extends between 121.7 and $169.6 \mathrm{~m}$ sub-bottom in Hole $626 \mathrm{C}$ and is dominated by a 35.4 -m-thick (124.6$160.0 \mathrm{~m}$ sub-bottom) debris flow. This debris flow grades from an unlithified clast-skeletal-foraminiferal floatstone near the base (Fig. 7) to an unlithified clast-foraminiferal-skeletal packstone near the top, which is defined by the last appearance of clasts at the top of Section 6 in Core $626 \mathrm{C}-14 \mathrm{H}$. Clasts consist dominantly of lithified skeletal grainstone and packstone; skeletal fragments are principally of shallow-water origin. Particularly large skeletal fragments in this debris flow consist of shallowplatform oyster and coral fragments. Clasts range in size from $10 \mathrm{~cm}$ at the base to $0.2 \mathrm{~cm}$ at the top. Separating this thick debris flow from an overlying (122.2-124.5 m sub-bottom) thinner (2.3-m) debris flow is a 0.1 -m-thick layer of foraminifer-nannofossil ooze. The thick debris flow is underlain by a short $(2.2-\mathrm{m})$ interval of unlithified to semilithified, glauconite-rich foraminiferal and foraminiferal-skeletal packstone and a lithified layer of skeletal grainstone (Fig. 8). This grainstone consists entirely of displaced shallow-water-platform debris and may represent a sediment gravity flow, either a turbidite or grainflow. The base of Unit II (162.2-169.6 m sub-bottom) consists of a third debris-flow unit, again grading from unlithified clast-skeletal-foraminiferal floatstone at the base to unlithified clast-foraminiferal-skeletal packstone at the top (Core 626C-18H). Several individual debris flows may constitute this third debris-flow unit.

In Hole 626B, Unit II consists of an interval of unlithified clast-foraminiferal-skeletal floatstone recovered in Core 626B-4R 
Table 1. Coring summary, Site 626.

\begin{tabular}{|c|c|c|c|c|c|c|c|}
\hline $\begin{array}{l}\text { Core } \\
\text { no. }\end{array}$ & $\begin{array}{l}\text { Core } \\
\text { type }^{a}\end{array}$ & $\begin{array}{l}\text { Date } \\
\text { (Feb. } \\
\text { 1985) }\end{array}$ & Time & $\begin{array}{l}\text { Sub-bottom } \\
\text { depths } \\
\text { (m) }\end{array}$ & $\begin{array}{l}\text { Length } \\
\text { cored } \\
\text { (m) }\end{array}$ & $\begin{array}{l}\text { Length } \\
\text { recovered } \\
\text { (m) }\end{array}$ & $\begin{array}{l}\text { Percentage } \\
\text { recovered }\end{array}$ \\
\hline \multicolumn{8}{|c|}{ Hole $626 \mathrm{~A}$} \\
\hline 1 & $\mathbf{R}$ & 1 & 1255 & $0-1.4$ & 1.4 & 1.44 & 102 \\
\hline 2 & $\mathbf{R}$ & 1 & 1825 & $1.4-12.8$ & 11.4 & 3.52 & 30 \\
\hline \multicolumn{8}{|l|}{ Hole 626B } \\
\hline 1 & w & 2 & 1055 & $0-80.2$ & 80.2 & 4.10 & 5 \\
\hline 2 & w & 2 & 1705 & $80.3-128.1$ & 47.9 & 0.03 & 0 \\
\hline 3 & $\mathbf{R}$ & 2 & 1915 & $128.1-137.7$ & 9.6 & 0 & 0 \\
\hline 4 & $\mathbf{R}$ & 2 & 2110 & $137.7-147.3$ & 9.6 & 6.97 & 72 \\
\hline 5 & w & 3 & 0150 & $147.3-185.5$ & 38.2 & 2.88 & 7 \\
\hline \multicolumn{8}{|l|}{ Hole $626 \mathrm{C}$} \\
\hline 1 & $\mathrm{x}$ & 3 & 1645 & $0-6.9$ & 6.9 & 0.04 & 0 \\
\hline 2 & $\mathrm{x}$ & 3 & 2000 & $6.9-16.5$ & 9.6 & 1.61 & 16 \\
\hline 3 & $\mathrm{X}$ & 3 & 2140 & $16.5-25.5$ & 9.0 & 5.10 & 56 \\
\hline 4 & $\mathrm{x}$ & 3 & 2240 & $25.5-35.1$ & 9.6 & 2.72 & 28 \\
\hline 5 & $\mathrm{x}$ & 3 & 2340 & $35.1-44.7$ & 9.6 & 1.09 & 11 \\
\hline 6 & $\mathrm{x}$ & 4 & 0115 & $44.7-54.3$ & 9.6 & 1.33 & 13 \\
\hline 7 & $\mathrm{x}$ & 4 & 0245 & $54.3-63.9$ & 9.6 & 0.05 & 0 \\
\hline 8 & $\mathrm{x}$ & 4 & 0420 & $63.9-73.4$ & 9.5 & 0 & 0 \\
\hline 9 & $\mathrm{x}$ & 4 & 0530 & $73.4-83.0$ & 9.6 & 0.66 & 6 \\
\hline 10 & $\mathrm{x}$ & 4 & 0730 & $83.0-92.7$ & 9.7 & 0 & 0 \\
\hline 11 & $\mathrm{x}$ & 4 & 0925 & $92.7-102.4$ & 9.7 & 0.10 & 1 \\
\hline 12 & $\mathrm{x}$ & 4 & 1045 & $102.4-112.1$ & 9.7 & 0 & 0 \\
\hline 13 & H & 4 & 1500 & $112.1-121.7$ & 9.6 & 5.13 & 53 \\
\hline 14 & H & 4 & 1700 & $121.7-131.3$ & 9.6 & 9.30 & 96 \\
\hline 15 & $\mathrm{H}$ & 4 & 1830 & $131.3-140.8$ & 9.5 & 9.75 & 102 \\
\hline 16 & H & 4 & 1905 & $140.8-150.4$ & 9.6 & 9.77 & 101 \\
\hline 17 & $\mathrm{H}$ & 4 & 1945 & $150.4-160.0$ & 9.6 & 9.64 & 100 \\
\hline 18 & $\mathrm{H}$ & 4 & 2105 & $160.0-169.6$ & 9.6 & 9.31 & 97 \\
\hline 19 & $\mathrm{H}$ & 4 & 2245 & $169.6-179.3$ & 9.7 & 0.74 & 7 \\
\hline \multicolumn{8}{|c|}{ Hole 626D } \\
\hline 1 & $\mathbf{R}$ & 5 & 2215 & $179.4-189.0$ & 9.6 & 1.37 & 14 \\
\hline 2 & $\mathrm{R}$ & 5 & 2345 & $189.0-198.6$ & 9.6 & 0 & 0 \\
\hline 3 & $\mathrm{R}$ & 6 & 0215 & $198.6-208.1$ & 9.5 & 0.57 & 6 \\
\hline 4 & $\mathrm{R}$ & 6 & 0305 & $208.1-217.7$ & 9.6 & 0.24 & 2 \\
\hline 5 & $\mathbf{R}$ & 6 & 0445 & $217.7-227.3$ & 9.6 & 0 & 0 \\
\hline 6 & $\mathrm{R}$ & 6 & 0710 & $227.3-236.9$ & 9.6 & 0.01 & 0 \\
\hline 7 & $\mathbf{R}$ & 6 & 1045 & $236.9-245.6$ & 8.7 & 0 & 0 \\
\hline 8 & $\mathrm{R}$ & 6 & 1415 & $245.6-255.2$ & 9.6 & 0 & 0 \\
\hline 9 & $\mathrm{R}$ & 6 & 1645 & $255.2-264.8$ & 9.6 & 0 & 0 \\
\hline 10 & $\mathrm{R}$ & 6 & 1845 & $264.8-274.4$ & 9.6 & 0 & 0 \\
\hline 11 & $\mathbf{R}$ & 6 & 1945 & $274.4-283.7$ & 9.3 & 1.33 & 14 \\
\hline 12 & $\mathrm{R}$ & 6 & 2105 & $283.7-293.2$ & 9.5 & 0 & 0 \\
\hline 13 & $\mathrm{R}$ & 6 & 2215 & $293.2-302.9$ & 9.7 & 1.45 & 14 \\
\hline 14 & $\mathbf{R}$ & 6 & 2335 & $302.9-312.6$ & 9.7 & 1.15 & 11 \\
\hline 15 & $\mathrm{R}$ & 7 & 0137 & $312.6-322.2$ & 9.6 & 0 & 0 \\
\hline 16 & R & 7 & 0405 & $322.2-331.8$ & 9.6 & 0.01 & 0 \\
\hline 17 & $\mathbf{R}$ & 7 & 0645 & $331.8-341.3$ & 9.5 & 0.01 & 0 \\
\hline 18 & $R$ & 7 & 0835 & $341.3-351.0$ & 9.7 & 0 & 0 \\
\hline 19 & R & 7 & 1045 & $351.0-360.7$ & 9.7 & 0.32 & 3 \\
\hline 20 & R & 7 & 1230 & $360.7-370.4$ & 9.7 & 0.56 & 5 \\
\hline 21 & $\mathrm{R}$ & 7 & 1335 & $370.4-380.1$ & 9.7 & 0.83 & 8 \\
\hline 22 & $\mathrm{R}$ & 7 & 1500 & $380.1-389.6$ & 9.5 & 0 & 0 \\
\hline 23 & $\mathrm{R}$ & 7 & 1645 & $389.6-399.3$ & 9.7 & 1.06 & 10 \\
\hline 24 & $\mathbf{R}$ & 7 & 1800 & $399.3-408.9$ & 9.6 & 0 & 0 \\
\hline 25 & R & 7 & 1925 & $408.9-418.5$ & 9.6 & 0 & 0 \\
\hline 26 & $\mathrm{R}$ & 7 & 1925 & $418.5-427.7$ & 9.2 & 0 & 0 \\
\hline 27 & $\mathrm{R}$ & 7 & 2050 & $427.7-437.3$ & 9.6 & 0.47 & 4 \\
\hline 28 & $\mathbf{R}$ & 7 & 2222 & $437.3-446.8$ & 9.5 & 0.01 & 0 \\
\hline
\end{tabular}

\footnotetext{
${ }^{\mathrm{a}} \mathrm{H}=$ hydraulic piston; $\mathrm{R}=$ rotary; $\mathrm{W}=$ wash $\mathrm{X}=$ extended core barrel.
}

at $137.7-147.3 \mathrm{~m}$ sub-bottom. This unit is interpreted as a debris-flow deposit on the basis of correlation with Hole $626 \mathrm{C}$.

\section{Unit III (169.6-446.8 m sub-bottom; Core 626B-5W; Core 626C-19H; Cores 626D-1R to 626D-28R)}

Unit III underlies the mass flow deposits making up Unit II. The uppermost part of Unit III is similar to the sediments in the interval separating the two debris flows in Unit II. A lithified layer of skeletal grainstone containing dead oil lies between unlithified foraminiferal-skeletal packstone. In addition, fragments of lithified skeletal grainstone were recovered in the core catcher of Core $626 \mathrm{D}-1 \mathrm{R}$. These lithified grainstones may represent mass gravity flows, similar to the lithified grainstone separating the two debris flows of Unit II. The packstone represents partly winnowed perennial sediment. 


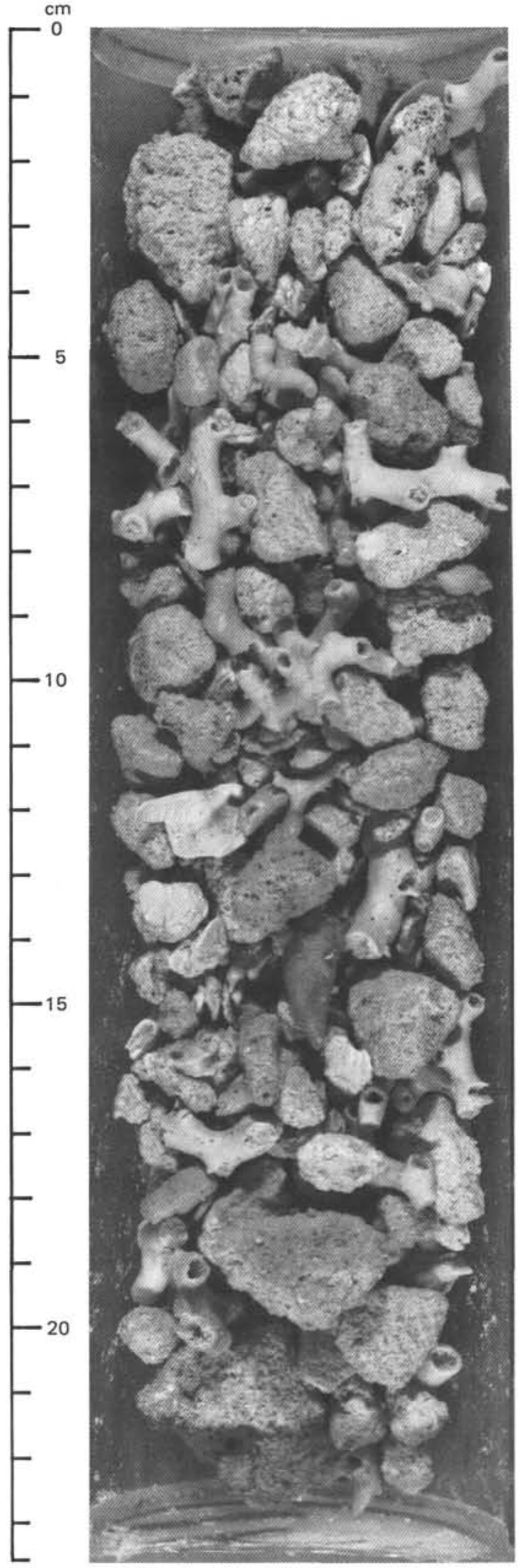

Figure 6. Coarse gravel (clast-skeletal rudstone) recovered from the seafloor at Hole 626A. Skeletal fragments are dominantly pieces of ahermatypic coral, with subordinant amounts of whole and broken bivalves, bryozoans, and echinoid spines. Clasts are lithified skeletal grainstones, with the skeletal component principally of shallow-water origin. Section 626A-1R, CC, Unit IA. $\mathrm{cm}$

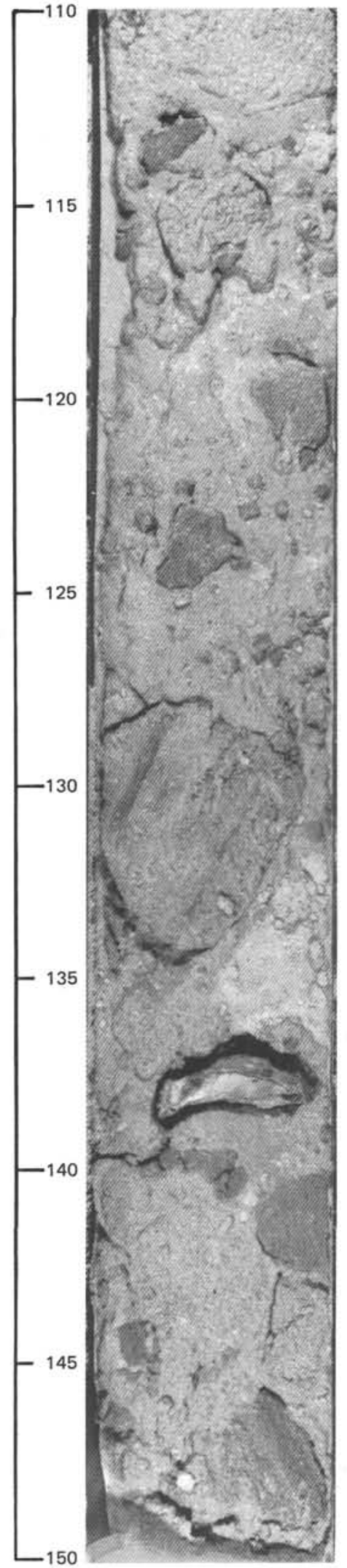

Figure 7. Part of upper debris flow (unlithified clast-skeletal-foraminiferal floatstone), showing large $(5-\mathrm{cm})$ clasts and a skeletal fragment (oyster) in a matrix of foraminifers, skeletal fragments, and micrite. Section $626 \mathrm{C}-17 \mathrm{H}-3,110-150 \mathrm{~cm}, 154.5-154.9 \mathrm{~m}$ sub-bottom, Unit II. 


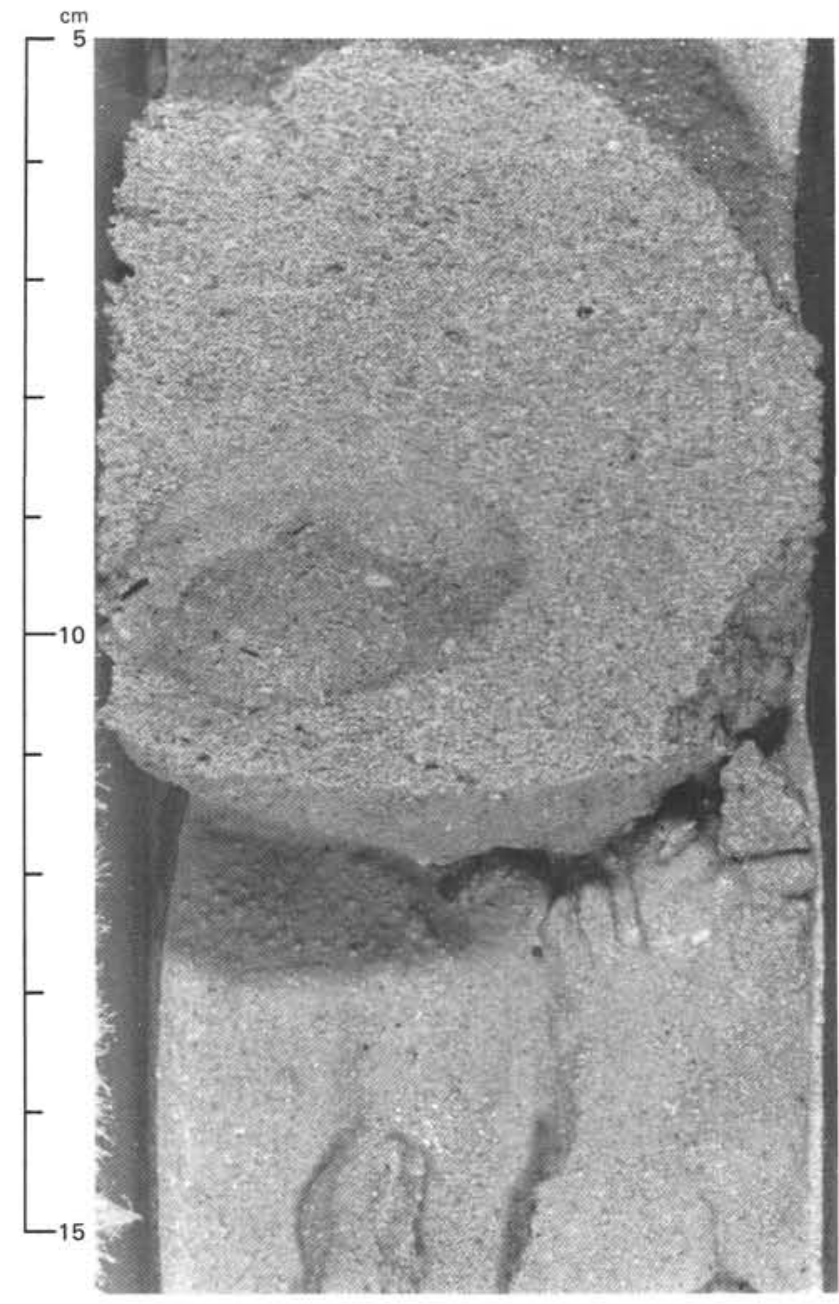

Figure 8. Lithified layer of skeletal grainstone separating debris flows. Skeletal fragments are principally of shallow-water origin. Layer is laminated except for an oval-shaped burrow. Sample $626 \mathrm{C}-18 \mathrm{H}-1,5-15 \mathrm{~cm}$, $160 \mathrm{~m}$ sub-bottom, Unit II.

The dominant lithology in Hole 626D (recovered in 9 of 11 cores) is an unlithified clast-skeletal-foraminiferal packstone. Clasts generally consist of lithified skeletal packstone and grainstone. Again, these packstones represent sediments that have been partly winnowed by the Florida Current. Core 626D-3R contains unlithified clast rudstone and grainstone, and Core 626D-4R contains an unlithified, glauconitic foraminiferal grainstone. These grainstones and rudstones represent sediments that have been thoroughly winnowed by the Florida Current. Their juxtaposition with only partly winnowed packstones indicates fluctuations in velocity of the Florida Current during deposition of Unit III.

Core cuttings in Cores 626D-6R, 626D-15R, 626D-16R, 626D$17 \mathrm{R}, 626 \mathrm{D}-25 \mathrm{R}$, and $62 \mathrm{D}-28 \mathrm{R}$ are essentially all lithified skeletal grainstones (Fig. 9). They presumably represent lithified layers interbedded with unlithified layers represented by the sediments recovered in other cores in this section. Chert fragments (dark olive gray, 5Y 3/2) also were recovered in Cores 626D$16 \mathrm{R}, 626 \mathrm{D}-17 \mathrm{R}, 626 \mathrm{D}-19 \mathrm{R}, 626 \mathrm{D}-20 \mathrm{R}$, and 626D-27R. The upper four occurrences coincide with a decrease in drilling rate and suggest that the interval from 322.2 to $370.4 \mathrm{~m}$ sub-bottom is cherty. Based on this drastic change in drilling rates and the concomitant appearance of chert in the interval 322.2-370.4 m sub-bottom, we have subdivided Unit III into three subunits:

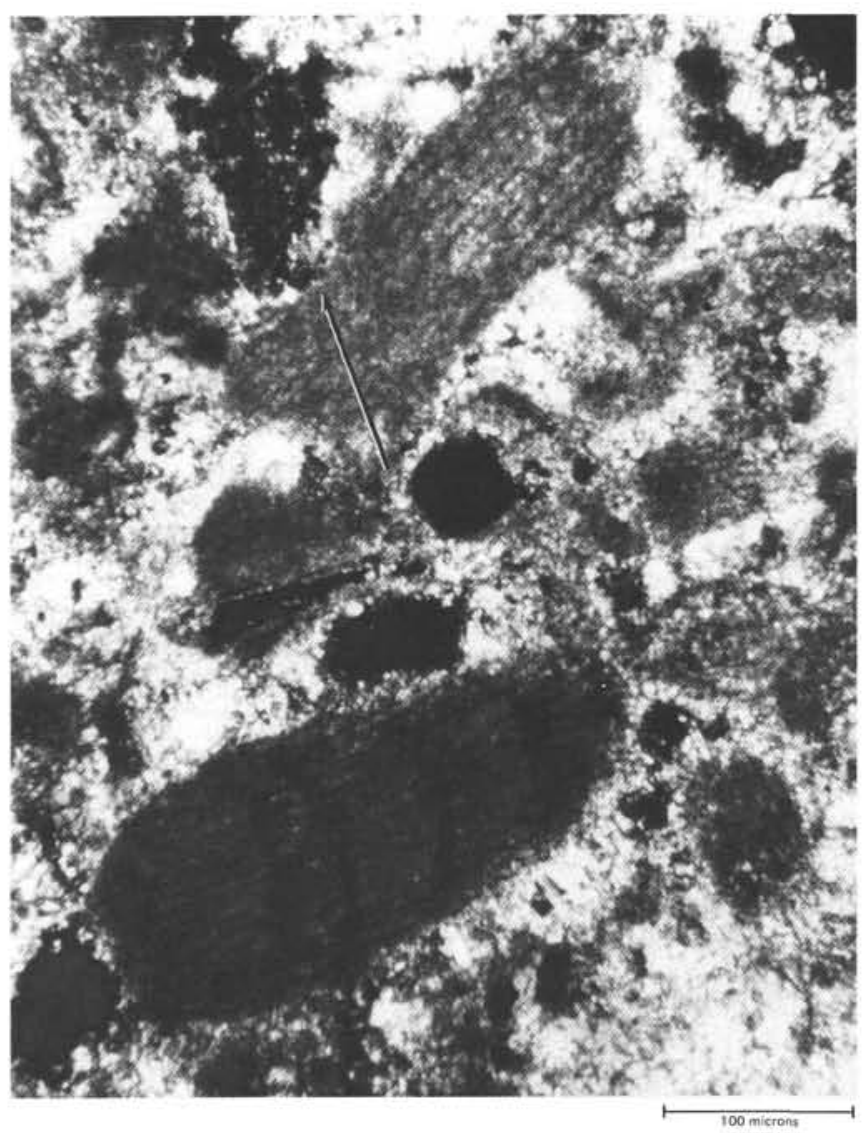

Figure 9. Thin-section photomicrograph of lithified skeletal grainstone (crossed nicols). Grains are principally of shallow-water origin and consist of fragments of red algae, echinoid spines, micritized skeletal fragments, and foraminifers. Cement is finely crystalline spar. Note pressure-solution contact between echinoid spine and red algal fragment at right. Bar is 100 microns. Section 626D-28R, CC, 437.3-446.8 m subbottom, Unit III.

Subunit IIIA (169.6-322.2 m sub-bottom), representing unlithified clast-skeletal-foraminiferal packstones and grainstones.

Subunit IIIB (322.2-370.4 m sub-bottom), assumed to consist of similar unlithified packstones and grainstones as Subunit IIIA with numerous interbeds of chert and limestone.

Subunit IIIC (370.4-446.8 m sub-bottom), similar to Subunit IIIA and containing only minor amounts of limestone.

It is likely that Subunit IIIA contains lithified layers in the interval from 236.9 to $274.4 \mathrm{~m}$ sub-bottom, based on a decrease in drilling rate. However, this interval has not been designated as a separate unit because Cores 626D-7R to 626D-10R recovered no sediment or rock; thus no lithologic control exists for this interval.

In Hole 626B, Unit III is represented by an interval of unlithified foraminiferal-skeletal grainstone, recovered in Core $626 \mathrm{D}-5 \mathrm{R}$ (147.3-185.5 m sub-bottom), overlying several centimeters of unlithified, homogeneous foraminiferal-skeletal packstone, which in turn overlies three large $(>5 \mathrm{~cm})$ clasts of lithified skeletal grainstone and laminated calcareous mudstone. These sediments and rocks were recovered from a washed interval, and so their exact stratigraphic relationships are uncertain. However, the juxtaposition of foraminiferal-skeletal grainstones and packstones in Core 626D-5R implies some variation in the intensity of winnowing by the Florida Current during deposition of Unit III and hence minor fluctuations in its velocity. 


\section{Discussion}

A number of cores contain graded intervals; however, except for Cores 626B-5W and $626 \mathrm{C}-13 \mathrm{H}$, where graded intervals overlie a finer grained section, the grading extends throughout the total sediment recovered in a single core. Thus all grading is believed to be an artifact produced by drilling and not a product of turbidite deposition.

The mass-gravity-flow deposits sampled in Holes 626B and $626 \mathrm{C}$ are middle Miocene in age. They are therefore coeval, in part, with the early to middle Miocene Great Abaco Member of the Blake Ridge Formation (Bliefnick et al., 1983). However, Site 626 mass gravity flows and mass gravity flows in the Great Abaco Member are lithologically distinct. For example, Site 626 mass gravity flows contain no radiolarian-diatom mudstone intraclasts. In addition, the thickness of Site 626 mass gravity flows is only $57.5 \mathrm{~m}$, whereas the Great Abaco Member attains thicknesses of nearly $500 \mathrm{~m}$. Furthermore, Site 626 mass gravity flows remain unlithified, whereas the Great Abaco Member is fully lithified. Nevertheless, the close temporal association of these two mass gravity flows and their occurrence in the vicinity of the Bahama Platform suggest a related origin.

The sandy and gravelly nature of the section at Site 626 is clearly the result of winnowing by the Florida Current since at least the late Oligocene. Apart from the mass gravity flows, the deposits are essentially contourites. They presented a difficult problem in sampling because, under the influence of drilling fluids (seawater and mud), they turned into quicksand and flowed away from the core barrel. Only when the HPC was used were full cores obtained. The interbedding of grainstones and rudstones with packstones clearly indicates fluctuations in the intensity of winnowing by the Florida Current and hence of its current velocity.

Lithified layers cored at Site 626 apparently were cemented in the subsurface. These layers show no evidence of boring or corrosion expected for surficial hardgrounds. Such layers are not plentiful in Unit I. They are, however, abundant (about 50\%) in Unit III, as indicated by decreased drilling rates and relatively low porosity on the porosity log. The cement lithifying these layers may be derived from dissolution of shallow-water skeletal fragments composed of aragonite and magnesian calcite. The dominance of skeletal fragments of shallow-water origin in lithified layers, and their subordinance in unlithified sands, support such an interpretation. It is not clear whether or not the lithified cuttings recovered in Hole 626D are pieces of such lithified layers or clasts washed from debris flows.

In summary, the section drilled at Site 626 consists of three major units: (1) Unit I, 0-121.7 m sub-bottom, foraminiferalskeletal packstone and grainstone; (2) Unit II, 121.7-169.6 m sub-bottom, clast-foraminiferal-skeletal floatstone; (3) Unit III, 169.6-446.8 m sub-bottom, clast-foraminiferal-skeletal packstone and grainstone.

\section{BIOSTRATIGRAPHY}

\section{Introduction}

Site 626 was chosen to examine the nature of prominent seismic horizons in the eastern Straits of Florida in order to facilitate their correlation with better documented areas in the North Atlantic Ocean and the Gulf of Mexico. In addition, drilling at the site would help to clarify and document the history of the Gulf Stream.

Three groups of microfossils were examined in the shipboard labs. Planktonic foraminifers and calcareous nannofossils were used to establish a biostratigraphic framework for the core material and to monitor the degree of pelagic reworking through time. Larger foraminifers were examined to monitor the input of redeposited shallow-water-platform microfossils to the site as well as to identify sediments containing shallow-water material reworked from older strata.

All depths referred to are sub-bottom depths, and samples are from the core catcher unless otherwise specified.

\section{Calcareous Nannofossils}

\section{Hole 626A}

Drilling at Hole 626A was abbreviated owing to the unstable nature of the sediment. Core $626 \mathrm{~A}-1 \mathrm{R}$, taken at or near the mud line, consists of less than one full section of coarse bioclastic limestone with abundant ahermatypic corals and few bryozoan fragments. Nannofossils were isolated by gravitational settling from this coarse debris. The settled samples contain few nannofossils with moderate to good preservation. The dominant nannofossils include a late Quaternary assemblage including Emiliania huxleyi, Gephyrocapsa caribbeanica, and small Gephyrocapsa spp., indicating nannofossil Zone NN21. Reworked forms include Sphenolithus abies (late Miocene-early Pliocene) and Watznaueria barnesae (Cretaceous). Core 626A-2R (12.8 m subbottom) contains finer grained calcareous sands with more abundant nannofossils of Zone NN21. Reworked forms are more common, with taxa such as Pseudoemiliana lacunosa (late Plioceneearly Quaternary), S. abies, Reticulofenestra pseudoumbilica (late Miocene-early Pliocene), Markalius astroporous (CretaceousOligocene), and Watznaueria barnesae (Cretaceous). This suggests that at least three, and possibly more, stratigraphic zones have been reworked by local bottom-current activity.

\section{Hole 626B}

Drilling at Hole 626B recovered three washed cores and two rotary cores. Nannofossil preservation is generally poor in these sections. Most samples contain only traces of nannofossil material, with mixed assemblages consisting of Quaternary and older material. Only one core (626B-1W) contains an assemblage rich enough to yield a reliable biostratigraphic age, although nannofossils from the late Pleistocene, early Pliocene, and late Miocene were recovered. The predominant assemblage in this sample is Miocene, including such forms as Discoaster quinqueramus, $D$. challengeri, $D$. berggreni, and $D$. variabilis. This assemblage indicates a late Miocene age (NN11), an age that is corroborated by planktonic foraminifers.

\section{Hole $626 \mathrm{C}$}

Hole $626 \mathrm{C}$ was drilled with the XCB (Cores $626 \mathrm{C}$-1 X through $626 \mathrm{C}-12 \mathrm{X}$ ) and with the advanced HPC (Cores $626 \mathrm{C}-13 \mathrm{H}$ through $626 \mathrm{C}-19 \mathrm{H})$. Core $626 \mathrm{C}-1 \mathrm{X}$ recovered only coral remains and pebbles that contained no nannofossils. Cores $626 \mathrm{C}-2 \mathrm{X}$ through $626 \mathrm{C}-5 \mathrm{X}$ can be confidently assigned to the late Pleistocene-Holocene nannofossil Zone NN21, based on Emiliana huxleyi, Gephyrocapsa oceanica, small Gephyrocapsa spp., and Umbellosphaera irregularis. The core catcher from Core $626 \mathrm{C}$ 6X lacks $E$. huxleyi but contains Pseudoemiliana lacunosa, indicating Zone NN19 of early Pleistocene age. This Pleistocene assemblage contains significant amounts of reworked material from older Neogene assemblages. The predominant source of the reworked material appears to be strata of early Pliocene age similar to that which underlies the Pleistocene section at this hole. Specimens of Cretaceous forms, such as Watznaueria barnesae and Cretarhabdus crenulatus, are a rare but consistent component of the reworked assemblage. The Pleistocene assemblages are generally well preserved, with only slight evidence of dissolution and overgrowth. The reworked Neogene material is noticeably more altered by diagenesis. The Cretaceous reworked component varies in preservational state within a sample from poor to good. 
Core $626 \mathrm{C}-7 \mathrm{X}$ contains a late Miocene (NN12) assemblage including forms such as Discoaster berggreni, $D$. surculus, $D$. brouweri (early forms), D. tamalis, and Reticulofenestra pseudoumbilica. Preservation is moderate to good with some overgrowth evident in many specimens. Trace amounts of reworked Cretaceous taxa (especially $W$. barnesae) are present. The base of the Pliocene could not be recognized, as Core $626 \mathrm{C}-8 \mathrm{X}$ failed to recover any sediment.

Core 626C-9X contains assemblages that include Discoaster quinqueramus, $D$. berggreni, $D$. brouweri (early forms), and $D$. variabilis. This assemblage indicates a late Miocene (NN11) age for the material. The preservation of this assemblage is moderate to poor. Trace amounts of Cretaceous reworked nannofossils ( $W$. barnesae) occur in these sediments. Core 626C-10X did not contain any sediment. Core $626 \mathrm{C}-11 \mathrm{X}$ contained only strongly overgrown and dissolved nannofossils of Oligocene age. These are interpreted to be reworked forms based on the results of planktonic-foraminiferal examinations. Core 626C-13H largely consists of similar, reworked Oligocene forms. A few taxa, such as Discoaster variabilis and $D$. exilis, are present, however, which suggest a Miocene (NN5-9) age. All of the specimens in this sample exhibit strong diagenetic alteration. Core catchers from Cores $626 \mathrm{C}-14 \mathrm{H}$ and $626 \mathrm{C}-15 \mathrm{H}$ did not include any age-diagnostic nannofossils. Foraminiferal evidence indicates that these cores are middle Miocene. Cores $626 \mathrm{C}-16 \mathrm{H}$ through $626 \mathrm{C}-19 \mathrm{H}$ contain Sphenolithus heteromorphus without Helicopontosphaera ampliaperta, indicating nannofossil Zone NN5. The assemblages are sparse. Coring was discontinued following Core $626 \mathrm{C}$ $19 \mathrm{H}$ in order to rotary-drill toward the deep objectives at this site.

\section{Hole $626 D$}

Coring at Hole 626D commenced at $179.4 \mathrm{~m}$, following washing through the overlying sediment. Recovery was poor throughout the cored interval in this hole. Sufficient sediment was recovered from some cores, however, to allow recognition of nannofossil zones for part of the hole. Cores 626D-1R, 626D-3R, and 626D-4R contain Sphenolithus heteromorphus and S. moriformis without Helicopontosphaera ampliaperta. This assemblage is indicative of middle Miocene nannofossil Zone NN5. Assemblages from Core 626D-1R are sparse and contain common reworked Oligocene forms (such as Sphenolithus ciperoenis and Reticulofenestra abisecta) as well as some Pleistocene downhole contaminants. Cores 626D-3R and 626D-4R have much richer, better preserved assemblages with only a trace of Oligocene reworking and no appreciable Pleistocene downhole contamination. Cores $626 \mathrm{D}-5 \mathrm{R}$ through $626 \mathrm{D}-9 \mathrm{R}$ recovered no nannofossil-bearing sediment. Cores 626D-10R through 626D13R contained sediment of early Miocene nannofossil Zone $\mathrm{NN} 3$, as indicated by the presence of Sphenolithus belemnos without Triquetrorhabdulus carinatus. In Core 626D-14R, both species were found, and therefore this sparse flora can be assigned to Zone NN2 of early Miocene age. No nannofossils were recovered from Cores 626D-15R through 626D-17R. In Cores 626D-18R and 626D-19R, S. belemnos and $T$. carinatus occur together in significant abundance, indicating the early Miocene nannofossil Zone NN2. Nannofossils are few to rare in this interval, with only moderate preservation. Only trace amounts of Cretaceous reworking (Watznaueria barnesae) are evident. No age-diagnostic nannofossils were observed in Core 626D-20R. Cores 626D-21R and (probably) 626D-22R contained an earliest Miocene assemblage (NN1) with moderately preserved, common nannofossils. Assignment of Core 626D-22R is difficult owing to the transitional nature of the assemblage. It may belong to the latest Oligocene NP25 Zone, although further study will be necessary to confirm this. Cores 626D-23R through 626D-27R are of the late Oligocene NP25 Zone based on the occurrence of Sphenolithus ciperoensis and Reticulofenestra abisectus. Some specimens of $R$. abisectus seem to be reworked from older Oligocene strata. In addition, a shallow-water form of Zygrhablithus bijugatus is present. No age-diagnostic forms were recovered from Core 626D-28R.

\section{Planktonic Foraminifers}

\section{Hole 626A}

Two rotary cores (1.4 $\mathrm{m}$ and $12.8 \mathrm{~m}$ sub-bottom) recovered Pleistocene sediments (Globorotalia truncatulinoides Zone, N22/ N23) at Hole 626A. A mixture of carbonate-platform and deeper water benthic species is present in both cores, with the proportion of platform species lessening in Core 626A-2R $(12.8 \mathrm{~m})$. Reworked Pliocene and Miocene planktonic species are present in small numbers in both cores.

\section{Hole $626 B$}

Hole $626 \mathrm{~B}$ was washed to $80.3 \mathrm{~m}$ sub-bottom. The planktonic-foraminiferal assemblage from this level contains downhole contamination of Pleistocene species. The co-occurrence of Globoquadrina dehiscens and Globorotalia margaritae is anomalous and indicates reworking of the former or downhole contamination of the latter. As this question could not be resolved, an early Pliocene to late Miocene age (Globorotalia margaritae Zone to Neogloboquadrina acostaensis Zone, N18/N19 part) is assigned to this level.

A second washed interval to $128.1 \mathrm{~m}$ sub-bottom contains an upper Miocene Globorotalia mayeri (N13 part/N14) Zone fauna. Species present include Globorotalia mayeri, G. menardii, and Globigerina nepenthes. Core 626B-3R (137.7 m) was retrieved empty. Core 626B-4R (147.3 m) contains middle Miocene sediments of the Globorotalia fohsi lobata/robusta Zone (N11 part/N12/N13 part). Species present include Globorotalia fohsi robusta, G. fohsi lobata, G. fohsi peripheroacuta, and $G$. mayeri. The hole was then washed to a depth of $185.5 \mathrm{~m}$. Core 626B-5W contains a mixed early middle Miocene fauna. Diagnostic taxa include Globorotalia fohsi peripheroronda, G. fohsi peripheroacuta, G. fohsi fohsi, G. fohsi cf. lobata, G. praemenardii, Globigerinoides sicanus, and Praeorbulina glomerosa (s.l.).

\section{Hole $626 \mathrm{C}$}

Hole $626 \mathrm{C}$ was drilled using an XCB to a depth of $112.1 \mathrm{~m}$ (Cores 626C-1X through 626C-12X). Drilling then continued using an HPC to a depth of $179.3 \mathrm{~m}$ (Cores 626C-13H through $626 \mathrm{C}-19 \mathrm{H})$. Cores $626 \mathrm{C}-1 \mathrm{X}$ through $626 \mathrm{C}-6 \mathrm{X}(0-54.3 \mathrm{~m})$ are Pleistocene (Globorotalia truncatulinoides Zone, N22/N23). The co-occurrence of $G$. truncatulinoides and $G$. tosaensis at $54.3 \mathrm{~m}$ (base of Core 626C-6X) indicates an early Pleistocene age for this level. Only a small amount of volcanic ash was recovered from the core catcher of Core 626C-7X (63.9 m). Rare planktonic foraminifers include Globorotalia plesiotumida, Globigerina nepenthes, Globoquadrina altispira altispira, G. venezuela$n a$, and Globigerina nepenthes, which indicate an early Pliocene to late Miocene age. All planktonic specimens are small, perhaps owing to size sorting, and benthics are absent. Core 626C-8X (63.9 m) was empty. A late Miocene age (Neogloboquadrina acostaensis Zone, N16/N17) is indicated for Core 626C-9X (83.0 m), based on Neogloboquadrina acostaensis, Globoquadrina dehiscens, and Globorotalia plesiotumida. Core $626 \mathrm{C}-10 \mathrm{X}(92.7 \mathrm{~m})$ was retrieved empty.

Core $626 \mathrm{C}-11 \mathrm{X}(102.4 \mathrm{~m})$ contains sediments of late middle Miocene age (Globorotalia mayeri Zone, N13 part/N14). This is indicated by the presence of Globorotalia mayeri, G. menardii, and $G$. lenguaensis. Core $626 \mathrm{C}-12 \mathrm{X}$ was empty. Cores $626 \mathrm{C}$ $13 \mathrm{H}$ and $626 \mathrm{C}-14 \mathrm{H}(121.7 \mathrm{~m}, 131.3 \mathrm{~m})$ contain foraminifers di- 
agnostic of the middle Miocene Globorotalia fohsi lobata/robusta Zone (N11 part/N12/N13 part). Species present include Globorotalia fohsi lobata, G. fohsi fohsi, G. fohsi praefohsi, and G. praemenardii. Cores $626 \mathrm{C}-15 \mathrm{H}$ through $626 \mathrm{C}-18 \mathrm{H}(140.8 \mathrm{~m}-$ $169.6 \mathrm{~m}$ ) are contained within the middle Miocene Globorotalia fohsi fohsi Zone (N10/N11 part). Diagnostic taxa include Globorotalia fohsi fohsi, G. fohsi peripheroacuta, and G. praemenardii. Earliest middle Miocene sediments are present in Core $626 \mathrm{C}-19 \mathrm{H}(179.3 \mathrm{~m})$. Species indicative of the Globorotalia peripheroronda/Praeorbulina glomerosa Zones (N8 part/N9) include Globigerinoides sicanus, Praeorbulina? glomerosa s.1., and Globorotalia fohsi peripheroronda. Orbulina is absent, as are the younger members of the Globorotalia fohsi lineage.

\section{Hole 626D}

Hole $626 \mathrm{D}$ was washed to $179.4 \mathrm{~m}$ sub-bottom and then rotary-cored to $446.8 \mathrm{~m}$. Core 626D-1R $(189.0 \mathrm{~m})$ contains Globorotalia fohsi peripheroronda, G. fohsi peripheroacuta, and Globorotalia fohsi fohsi, indicating a middle Miocene age (Globorotalia fohsi fohsi Zone, N10/11 part). However, the occurrence of rare Praeorbulina glomerosa s.1. suggests that this level may actually be somewhat older (earliest middle Miocene; Globorotalia peripheroronda/Praeorbulina glomerosa Zones, N8 part/ N9). This latter view would agree with the age of Core $626 \mathrm{C}-19 \mathrm{H}$, in which case significant downhole mixing must be invoked to explain the abundance of $G$. fohsi fohsi Zone fauna in Core 626D-1R. Core 626D-2R (198.6 m) was empty. Core 626D-3R $(208.1 \mathrm{~m})$ contains an early middle Miocene fauna that includes Orbulina suturalis, Globorotalia fohsi peripheroronda, G. fohsi peripheroacuta, G. fohsi cf. praefohsi, and Praeorbulina glomerosa s.1., indicative of the Globorotalia fohsi peripheroronda Zone (N9). This assemblage, too, may be enriched in slightly younger middle Miocene faunas owing to caving of unconsolidated foraminiferal sands from above. Core 626D-4R (217.7 m) is of earliest middle Miocene age (Praeorbulina glomerosa Zone, N8 part/N9) as indicated by Praeorbulina glomerosa s.1., Globigerinatella insueta, and Globorotalia fohsi peripheroronda. Species of Orbulina and the younger members of the Globorotalia fohsi lineage are absent. Core 626D-5R (227.3 m) was empty. A fragment of lithified foraminiferal grainstone recovered from Core 626D-6R $(236.9 \mathrm{~m})$ contains Globorotalia mayeri and Globigerinoides spp. and is assigned an early to middle Miocene age. Cores 626D-7R, 626D-8R, 626D-9R, and 626D-12R (245.6 m, $255.2 \mathrm{~m}, 264.8 \mathrm{~m}, 293.2 \mathrm{~m}$ ) were empty.

Planktonic foraminifers are common in Cores 626D-10R, 626D-11R, and 626D-13R (274.4 m, $283.7 \mathrm{~m}, 302.9 \mathrm{~m})$, but no zonal-marker species are present. The absence of Praeorbulina and Catapsydrax suggests that these sediments are of late early Miocene age (probably Globigerinatella insueta Zone, N7/8 part). The top of the undifferentiated Catapsydrax stainforthi Zone and the Catapsydrax dissimilis Zone (N5/N6) is present in Core 626D-14R (312.6 m) where $C$. dissimilis first appears. The paucity of Globigerinatella insueta at Site 626 did not allow differentiation of these zones. Sediments of this age are present through Core 626D-19R (360.7 m). Cores 626D-15R, 626D-16R, and $626 \mathrm{D}-18 \mathrm{R}(322.2 \mathrm{~m}, 331.8 \mathrm{~m}, 351.0 \mathrm{~m})$ were empty. Core 626D-17R $(341.3 \mathrm{~m})$ consists of fragments of lithified foraminiferal grainstone containing Globigerinoides spp., indicating a Neogene age.

The early Miocene Globorotalia kugleri Zone (N4) is present in Core 626D-20R (370.4 m). The co-occurrence of Globorotalia kugleri and G. pseudokugleri suggests that the top of the zone lies above this level. Core 626D-21R $(380.1 \mathrm{~m})$ is also contained within this zone.

Core 626D-22R (389.6 m) is of earliest Miocene to latest Oligocene age. Species present include Globorotalia pseudokugle$r i$, G. cf. opima nana, and Globigerina cf. ciperoensis. Upper
Oligocene sediments belonging to the Globigerina ciperoensis Zone (P22) were recovered from Cores 626D-23R, 626D-24R, and 626D-27R (399.3 m, $408.9 \mathrm{~m}, 446.8 \mathrm{~m})$. Diagnostic taxa include Globigerina ciperoensis and Globorotalia opima nana. Cores 626D-25R, 626D-26R, and 626D-28R (418.5 m, $427.7 \mathrm{~m}$, $446.8 \mathrm{~m}$ ) were empty.

\section{Larger Benthic Foraminifers}

\section{Hole 626A}

Redeposited benthic foraminifers occur in the core catchers of Cores 626A-1R and 626A-2R. Taxa present include Amphistegina sp. gr. lessonii and Archaias angulatus. A. angulatus is known from the Oligocene to the Holocene, where it lives in very shallow platform waters.

\section{Hole $626 \mathrm{~B}$}

Samples from Core 626B-2W, CC and Core 626B-4R, CC contain redeposited larger foraminifers including Amphistegina sp. gr. lessonii, Nummulites cojimarensis, Sphaerogypsina vericularis, and Miogypsina antillea. This assemblage is indicative of a middle Miocene age, which agrees with the planktonic-foraminiferal biostratigraphy. Miogypsina antillea and Lepidocylina $\mathrm{sp}$. were found from 50 to $54 \mathrm{~cm}$ in Core 626B-5W, indicating an early to middle Miocene age, which also agrees with the planktonic-foraminiferal age.

\section{Hole $626 \mathrm{C}$}

Larger benthic foraminifers were also found in samples from this hole. Most of them can be interpreted as penecontemporaneously redeposited, although some of them are reworked from older stratigraphic zones (Butterlin and Moullade, 1983). Samples $626 \mathrm{C} 3 \mathrm{X}-3,50-52 \mathrm{~cm}, 626 \mathrm{C}-4 \mathrm{X}-2,50-52 \mathrm{~cm}$, and $626 \mathrm{C}-5 \mathrm{X}$, $\mathrm{CC}$ (dated as Pleistocene, N22/N23, based on planktonic foraminifers) contain Amphistegina sp. gr. lessonii, Sphaereogypsina sp., Gypsina vesicularis, and Archaias angulatus. The first two taxa are also present in Core $626 \mathrm{C}-13 \mathrm{H}, \mathrm{CC}$. Samples $626 \mathrm{C}$ $14 \mathrm{H}-5,50-52 \mathrm{~cm}, 626 \mathrm{C}-15 \mathrm{H}-7,50-52 \mathrm{~cm}$, and $626 \mathrm{C}-16 \mathrm{H}-2$, $50-52 \mathrm{~cm}$, contain Lepidocylina $(L)$ miraflorensis and Miogypsina antillea, indicating a middle Miocene age. Sample 626C$17 \mathrm{H}-5,51-53 \mathrm{~cm}$, yields only Nummulites cojimarensis, Amphistegina sp., Sphaereogypsina sp., and Miogypsina antillea. In Core 626C-18H, CC, Miogypsina antillea, Lepidocyclina $(L)$ canellei, Nummulites cojimarensis, Gypsina vesicularis, and Sphaerogypsina sp. are present, indicating the middle Miocene.

All these larger benthic foraminifers occur in the middle Miocene, but the genus Lepidocyclina disappears in sediments of early Miocene age, suggesting that it is reworked here. Most of the samples studied from Sections $626 \mathrm{C}-14 \mathrm{H}-1$ to $626 \mathrm{C}-18 \mathrm{H}$, $\mathrm{CC}$ contain larger foraminifers.

\section{Hole $626 \mathrm{D}$}

Many of the cores from Hole 626D contain a small number of moderately preserved, redeposited benthic foraminifers. Core 626D-1R, CC (assigned to planktonic-foraminiferal Zones N10/ N11) contains Amphistegina sp. gr. lessonii, Sphaereogypsina sp., Lenticulina sp., and Miogypsina antillea. The latter species occurs in the early and middle Miocene. This agrees with the planktonic-foraminiferal assignment of this interval to Zones N10/N11. Sections 626D-11R-2 and 626D-11R, CC yielded assemblages that include Miogypsina mexicana, Lepidocyclina canellei, L. (L) miraflorensis, Lepidocyclina $(L)$ giraudi, Lepidocyclina $(L)$ yuragunensis, and Nummulites cojimarensis. In the Caribbean province, Lepidocyclina $(L)$ canellei disappears within planktonic-foraminiferal Zones N7/N8. This indicates that this assemblage is of early Miocene age. Cores 626D-13R, CC and 626D-14R, CC contain Miogypsina sp. and Lepidocyclina 
sp. Core 626D-19R, CC yields Miogypsina cf. antillea and Heterostegina antillea. This assemblage indicates the early Miocene. Core 626D-20R, CC contains Miogypsina mexicana, Miogypsina gunteri, Heterostegina antillea, Gypsina sp., Amphistegina sp., Lepidocyclina $(L)$ giraudi, Lepidocyclina $(L)$ miraflorensis, Lepidocyclina $(L)$ canellei, Nummulites cf. dia, and Peneroplis discoideus. These forms indicate an early Micoene age, which agrees with the planktonic-foraminiferal age (N4). Some specimens of Lepidocyclina sp. and Heterostegina sp. are present in Cores 626D-21R, CC and 626D-23R, CC, but Core 626D-27R, $\mathrm{CC}$ contains only one fragment of Lepidocyclina $\mathrm{sp}$.

It appears that the larger foraminifers of the shallow platform present in Cores 626D-11R to 626D-20R have been redeposited penecontemporaneously in deep basins.

\section{Conclusions}

Despite hole problems, sufficient material was recovered to allow the construction of a reliable composite section for the upper Oligocene through Pleistocene.

Calcareous nannofossils are generally rare in the recovered core material. Much of this material was severely washed during coring operations. Downhole contamination was a frequent occurrence, with the problem being especially acute in upper parts of the cored sections. Nannofossil reworking from older sections was also a common phenomenon. This was especially troublesome in view of the generally sparse assemblages that were recovered. As a result, nannofossils provided much poorer biostratigraphic control at this site than the planktonic foraminifers.

Planktonic-foraminiferal tests constitute the bulk of the sediments recovered at Site 626. Preservation ranges from moderately poor to good. Many of the indigenous assemblages have been modified by mixing, either by recycling of older faunas and/or by downhole contamination. Downhole mixing of foraminiferal assemblages is an obvious problem in the washed intervals of Hole 626B (Cores 1W, 2W, and 5W), making age determinations tenuous. Mixing at Holes $626 \mathrm{C}$ and $626 \mathrm{D}$ was compounded by caving and poor sediment recovery in many cored intervals. Pleistocene assemblages of Holes $626 \mathrm{~A}$ and $626 \mathrm{C}$ contain reworked middle Miocene-early Pliocene taxa. Late Oligocene planktonics are recorded in the middle Miocene of Hole $626 \mathrm{C}$. Several core-catcher samples appear to be size sorted. It is questionable whether this size sorting is the product of deposition and subsequent modification by bottom currents or merely an artifact of coring unconsolidated sands.

The combination of calcareous-nannofossil and planktonicforaminiferal biostratigraphies indicates that a nearly complete Neogene section is preserved in the sediments of this site. Both late and early Pleistocene pelagic and/or hemipelagic sedimentation is recorded near the top of the sequence. A significant unconformity appears to separate the Pleistocene from the lower Pliocene (between Cores 626C-6X and 626C-7X, for example). Another unconformity may separate the upper Miocene-lower Pliocene section from the underlying middle Miocene, although the younger interval may be a condensed or reduced sequence. Sedimentation appears to have been relatively continuous from the late Oligocene through the early Miocene. It is possible that a minor break in the sedimentary record occurs within the lower Miocene (N4/N5). With the poor recovery, however, this cannot be adequately documented.

The larger benthic foraminifers found in the Site 626 material are neritic species derived from a shallow-water, platform environment. Specimens generally occur as isolated individuals as opposed to being incorporated within a limestone matrix. The larger foraminifers found in upper Oligocene to Pleistocene sediments in the four holes at Site $\mathbf{6 2 6}$ have biostratigraphic ranges that correlate with the results of other microfossil studies. This fact, and the disaggregated nature of the specimens, indicate that these specimens have been penecontemporaneously redeposited from the platform into the deep basin. An exception to this trend occurs in Core 626C-18, CC, where Lepidocyclina canellei was obviously reworked from older Miocene strata. However, no reworked macroforaminifers from the Eocene or Cretaceous have been recognized at Site 626 .

\section{SEDIMENT-ACCUMULATION RATES}

High sediment-accumulation rates (Fig. 10) characterize much of the upper Oligocene-Pleistocene section drilled at Site 626. Pleistocene sediments recovered at Hole $626 \mathrm{C}$ accumulated at a rate greater than $30 \mathrm{~m} / \mathrm{m}$.y., perhaps as high as $50 \mathrm{~m} / \mathrm{m}$.y. A hiatus of about 2-2.5 m.y. separates Pleistocene from lower Pliocene sediments. A relatively thin upper Miocene-lower Pliocene section was drilled at Hole $626 \mathrm{C}$, but owing to poor recovery, biostratigraphic age assignments are tentative through this interval; accumulation-rate estimates vary between 4 and $14 \mathrm{~m} / \mathrm{m} . \mathrm{y}$. Punctuated sedimentation, erosion, and/or reduced accumulation rates have characterized late Miocene-early Pliocene time at this site. Another stratigraphic break of perhaps one to several million years separates the middle Miocene from the upper Miocene.

A relatively complete upper Oligocene through middle Miocene sequence was deposited in the Site 626 area. Average sediment-accumulation rates were high through this interval but waned with time. The upper Oligocene-lowermost Miocene (Hole 626D) accumulated at an average rate in the range of 13$35 \mathrm{~m} / \mathrm{m}$.y., the lower Miocene to lowermost middle Miocene (Hole 626D) at an average rate of $39-50 \mathrm{~m} / \mathrm{m} . \mathrm{y}$, and the middle Miocene (Hole $626 \mathrm{C}$ ) at a reduced rate of about $18 \mathrm{~m} / \mathrm{m} . \mathrm{y}$.

\section{INORGANIC GEOCHEMISTRY}

\section{Interstitial Waters}

Four interstitial-water samples were taken from Hole $626 \mathrm{C}$ and analyzed for $(\mathrm{Ca}+\mathrm{Sr})$, total alkaline earths, alkalinity, chlorinity, salinity, and $\mathrm{pH}$ according to the methods described by Gieskes (1974). In addition, $\mathrm{SO}_{4}^{2-}$ was determined using ion chromatographic techniques. All samples were normalized to the IAPSO standard, and for purposes of the initial reports it will be assumed that the $\mathrm{Sr} / \mathrm{Ca}$ ratio of the squeezed waters remains similar to seawater. Results of this study are presented in Table 2 and Figure 11 (surface seawater is plotted at a depth of $0 \mathrm{~m}$ subbottom).

The sampling program for this site in general, particularly for Hole $626 \mathrm{C}$, was dictated by the recovery of undisturbed sediments suitable for squeezing. Therefore, considering the generally poor recovery, the distribution of samples is not particularly well suited to reflect changes in pore-water chemistry. Nevertheless, all geochemical parameters were observed to change with increasing burial (see Figs. 11 and 12). Salinity, chlorinity, alkalinity, and calcium values all increase with depth; $\mathrm{Mg}$ maintains a relatively constant composition, whereas $\mathrm{pH}$ shows a small decline.

The increase in Ca with depth is typical of that observed in other calcareous oceanic sediments (see Gieskes, 1981) and has been ascribed to the influence of the weathering of underlying basaltic material (Perry et al., 1976). Such reactions release both $\mathrm{Ca}$ and $\mathrm{Mg}$ to the pore waters, but subsequent formation of clay minerals depletes the waters in $\mathrm{Mg}$. If the increase in $\mathrm{Ca}$ at $\mathrm{Hole}$ $626 \mathrm{C}$ is a result of alteration of igneous materials, the source for such minerals must be local or detrital, as previously published studies indicate that between 3000 and $4000 \mathrm{~m}$ of carbonate sediment covers the underlying igneous basement materials (Tator and Hatfield, 1975). The further possibility exists that part of 


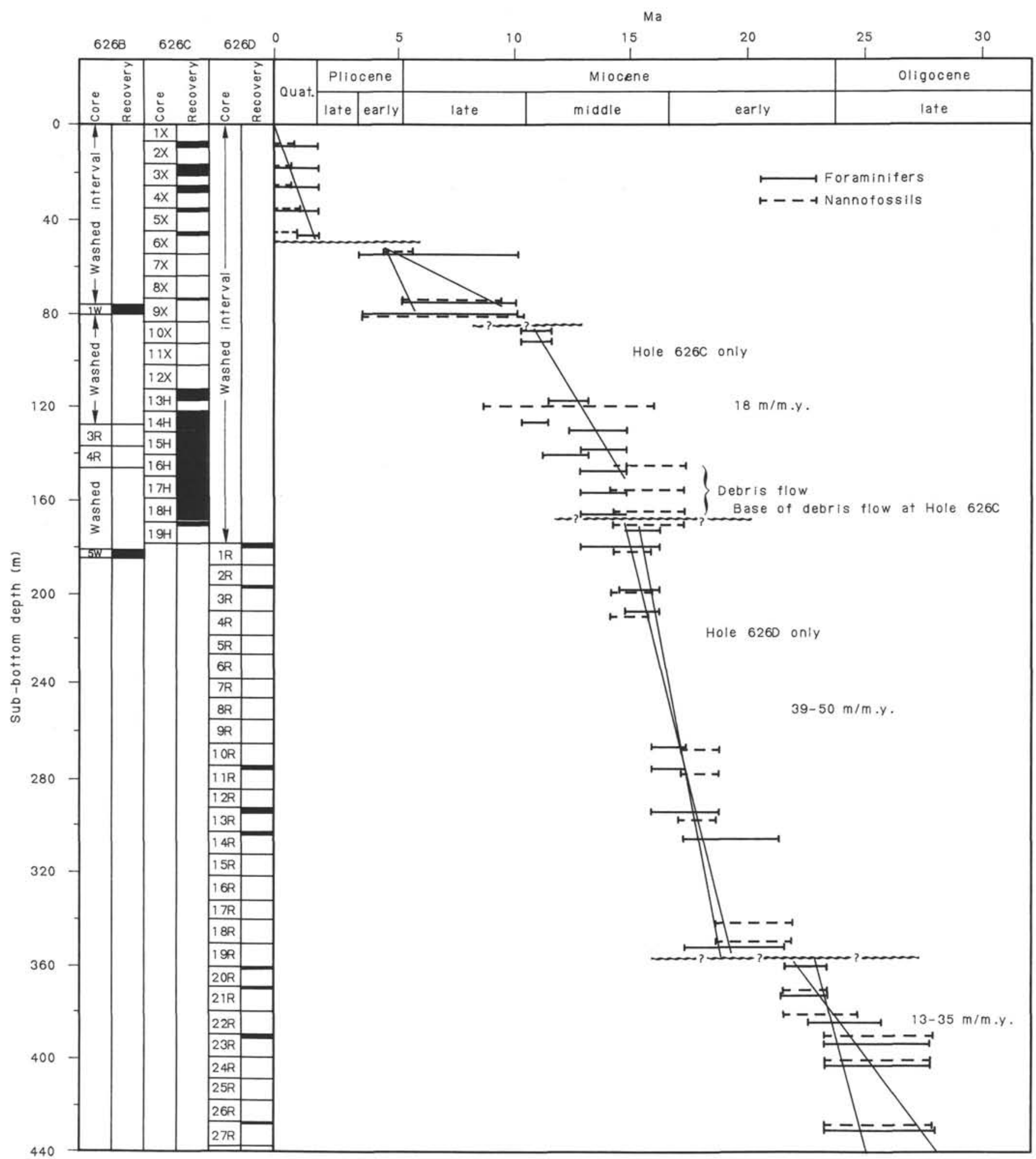

Figure 10. Sediment-accumulation rates for Site 626 (see "Biostratigraphy" section, this chapter).

the increase may be a result of changes in the concentration of $\mathrm{Sr}$, as the titration method used is unable to distinguish between these two elements. Such an increase may be a result of the dissolution of aragonite, which could also raise the observed $\mathrm{Ca}$ concentrations, as originally proposed by Sayles and Manheim (1975). Such a theory may be confirmed by the absence of any inverse correlation between $\mathrm{Ca}$ and $\mathrm{Mg}$, which might be expected if the model of Perry et al. (1976) is appropriate.

The precipitation of dolomite may further act to alter the $\mathrm{Mg}$ composition of interstitial pore waters, although it must be stressed that both concentrations of dolomite and the observed changes in $\mathrm{Mg}$ were extremely small. 
Table 2. Analyses of interstitial waters from Hole $626 \mathrm{C}$.

\begin{tabular}{lccccccc}
\hline \multicolumn{1}{c}{ Sample } & $\mathrm{pH}$ & $\begin{array}{c}\text { Alkalinity } \\
(\mathrm{meq} / \mathrm{kg})\end{array}$ & $\begin{array}{c}\text { Salinity } \\
(\% \mathrm{o})\end{array}$ & $\begin{array}{c}\text { Chlorinity } \\
(\% 0)\end{array}$ & $\begin{array}{c}\mathrm{Ca} \\
(\mathrm{mmol} / \mathrm{L})\end{array}$ & $\begin{array}{c}\mathrm{Mg} \\
(\mathrm{mmol} / \mathrm{L})\end{array}$ & $\begin{array}{c}\mathrm{SO}_{4} \\
(\mathrm{mmol} / \mathrm{L})\end{array}$ \\
\hline Surface seawater & 8.20 & 2.25 & 35.5 & 19.11 & 10.27 & 52.53 & 28.21 \\
626D-3X-3 & 7.83 & 1.81 & 36.4 & 19.41 & 10.13 & 50.99 & 27.78 \\
626D-14H & 7.44 & 3.36 & 37.0 & 19.84 & 14.40 & 52.10 & 26.16 \\
626D-15H & 7.38 & 3.28 & 37.5 & 20.13 & 16.22 & 45.46 & 26.17 \\
626D-18H & 7.33 & 3.62 & 38.0 & 20.66 & 14.25 & 52.19 & 28.34 \\
IAPSO standard & 8.02 & 2.32 & 35.5 & 19.37 & 10.55 & 53.99 & 28.9 \\
\hline
\end{tabular}

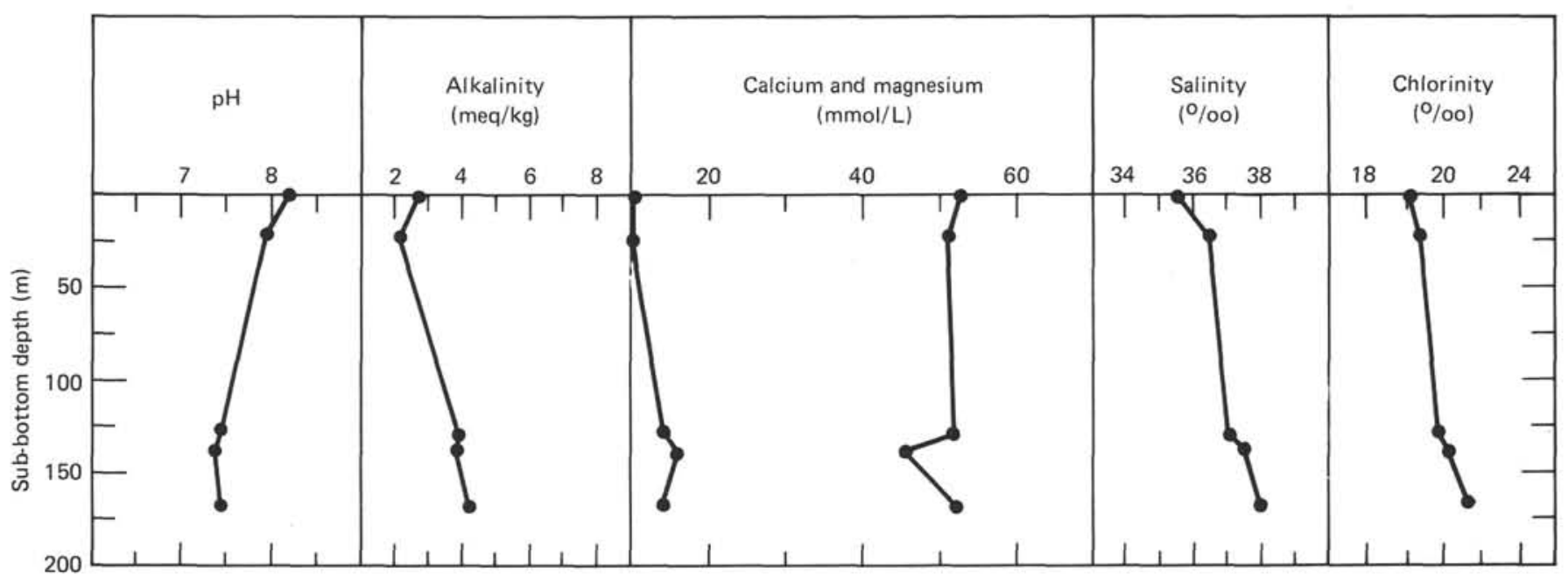

Figure 11. Interstitial-water summary, Hole $626 \mathrm{C}$.

No significant gradient was observed in the $\mathrm{SO}_{4}^{2-}$ content, in spite of the obvious presence of $\mathrm{H}_{2} \mathrm{~S}$.

\section{X-Ray Data from Bulk Samples}

Samples were taken from (1) the squeezed samples used for interstitial-water analysis from Hole $626 \mathrm{C}$ and (2) materials from the core catchers from Hole 626D. The results of these analyses (see Tables 3 and 4; Fig. 13) reveal that most of the sediments are now composed of low-Mg calcite, although small amounts of aragonite and high- $\mathrm{Mg}$ calcite were detected. In both Holes $626 \mathrm{C}$ and $626 \mathrm{D}$, concentrations of dolomite were measured, with compositions of $\mathrm{mol} \% \mathrm{MgCO}_{3}$ varying between $47 \%$ and $42 \%$.

\section{Carbonate-Bomb Analyses}

Carbonate-bomb data from Holes $626 \mathrm{C}$ and $626 \mathrm{D}$ appear in Table 5 and Figure 14. Values range from $90 \%$ to $100 \% \mathrm{CaCO}_{3}$, with no trends evident.

\section{ORGANIC GEOCHEMISTRY}

Seven rock samples were taken from Site 626 for analysis, using the Rock-Eval method. Preliminary data were also obtained on some asphaltic residues found in Cores 626C-1R, CC (lowermiddle Miocene) and 626C-19H, CC (lower Miocene). The RockEval data are given in Table 6.

The lithology at Site 626 appears to be fairly homogeneous. The sediments consist of a series of unlithified foraminiferalskeletal packstones and grainstones containing clasts of more lithified material. These lithologies consist almost entirely of calcium carbonate.

Rock-Eval data revealed that kerogen contained within these sands was usually immature $\left(\mathrm{T}_{\max }<420^{\circ} \mathrm{C}\right.$, reworked organic matter of type IV kerogen). These sediments were of poor sourcerock character $\left(\mathrm{S}_{2} / \mathrm{S}_{3}>2.0\right)$. From the production index, $\mathrm{S}_{1} /\left(\mathrm{S}_{1}\right.$
$+\mathrm{S}_{2}$ ) of all samples (except 626D-1R, CC), there is no clear indication of generated or migrated hydrocarbons.

Sample 626D-1R, CC was anomalous in its high $\mathrm{T}_{\max }$, high $\mathrm{S}_{2} / \mathrm{S}_{3}$ peak ratio, and relatively high $\mathrm{S}_{1}$ peak (see Table 5). These values, and the asymmetry of the $S_{2}$ peak, are typical of tarry, highly degraded oils that mainly contain high-molecular-weight, high-boiling-point components. The distortion of the $\mathrm{S}_{2}$ peak is a result of components still being volatilized when pyrolysis heating is terminated.

Section $626 \mathrm{C}-19 \mathrm{H}-1$ appeared to be similar visually but was retained unanalyzed for shore-based studies.

Both Sections 626C-19H-1 and 626D-1R, CC contain obvious specimens of asphalt as fine flecks, "strings," discrete grains, and as coatings on carbonate grains.

The asphalt was sparingly soluble in a trichloroethane and methanol (2/1) mixture. It did not fluoresce under ultraviolet light and consequently appeared to be heavily biodegraded.

The origin of this asphaltic material is controversial. A close examination of the textural relations of the asphalt blebs within the rock matrix shows a virtual absence of staining. Staining would be a fairly reliable guide that the asphaltic residues were formed from the migration of crude oil. An x-ray-diffraction study of the mineral matrix surrounding the asphalt grains showed that the dominant lithology was high-magnesium calcite and aragonite. These two unstable minerals, particularly the high-magnesium calcite, are highly susceptible to diagenetic alteration. Their combined presence indicates that the brines accompanying migrating oil were unlikely to have percolated through this rock. The asphalt grains are thus seen to be part of the primary depositional fabric. The implications are that the "dead oil" or asphalt found in the two zones originated from paleoseepage(s) or oil seepages into the water column during the early Miocene. This oil, after evaporation, biodegradation, and 
Table 3. X-ray analyses of samples from Hole 626D.

\begin{tabular}{|c|c|c|c|c|c|c|}
\hline \multirow[b]{2}{*}{ Sample } & \multicolumn{3}{|c|}{ Minerals } & \multicolumn{2}{|c|}{ Composition } & \multirow[b]{2}{*}{ Comments } \\
\hline & $\begin{array}{c}\text { Aragonite } \\
(\%)\end{array}$ & $\begin{array}{c}\text { Calcite } \\
(\%)\end{array}$ & $\begin{array}{c}\text { Dolomite } \\
(\%)\end{array}$ & $\begin{array}{c}\mathrm{CaCO}_{3} \\
(\%)\end{array}$ & $\underset{(\%)}{\mathrm{MgCO}_{3}}$ & \\
\hline $626 \mathrm{D}-1 \mathrm{R}, \mathrm{CC}$ & 13 & 87.0 & 0 & 90.25 & 9.73 & $\begin{array}{l}\text { High- } \mathrm{Mg} \text { calcite; } \\
\text { low- } \mathrm{Mg} \text { calcite }\end{array}$ \\
\hline 626D-11R, CC & 0 & 100.0 & 0 & 96.0 & 4.0 & \\
\hline 626D-14R, CC & 0 & 99.5 & 0.5 & $\mathrm{a}_{53.0}$ & $a_{47.0}$ & Low-Mg calcite \\
\hline $626 \mathrm{D}-17 \mathrm{R}, \mathrm{CC}$ & 0 & 98.0 & 2.0 & $a_{58.0}$ & $\mathrm{a}_{42.0}$ & Low-Mg calcite \\
\hline 626D-20R, CC & 2.6 & 95.2 & 2.2 & $a_{58.0}$ & ${ }^{a} 42.0$ & Low-Mg calcite \\
\hline $626 \mathrm{D}-23 \mathrm{R}, \mathrm{CC}$ & 0 & 96.6 & 3.4 & $a_{58.0}$ & $a_{42.0}$ & Low-Mg calcite \\
\hline 626D-25R, CC & 0 & 100.0 & 0 & $\sim 99.0$ & 0 & Hard clast \\
\hline 626D-26R, CC & 0 & 84.4 & 15.6 & $a_{55.0}$ & $a_{45.0}$ & Low-Mg calcite \\
\hline $626 \mathrm{D}-28 \mathrm{R}, \mathrm{CC}$ & 0 & 100.0 & 0 & $\sim 99.0$ & 0 & Hard clast \\
\hline
\end{tabular}

a Dolomite only.

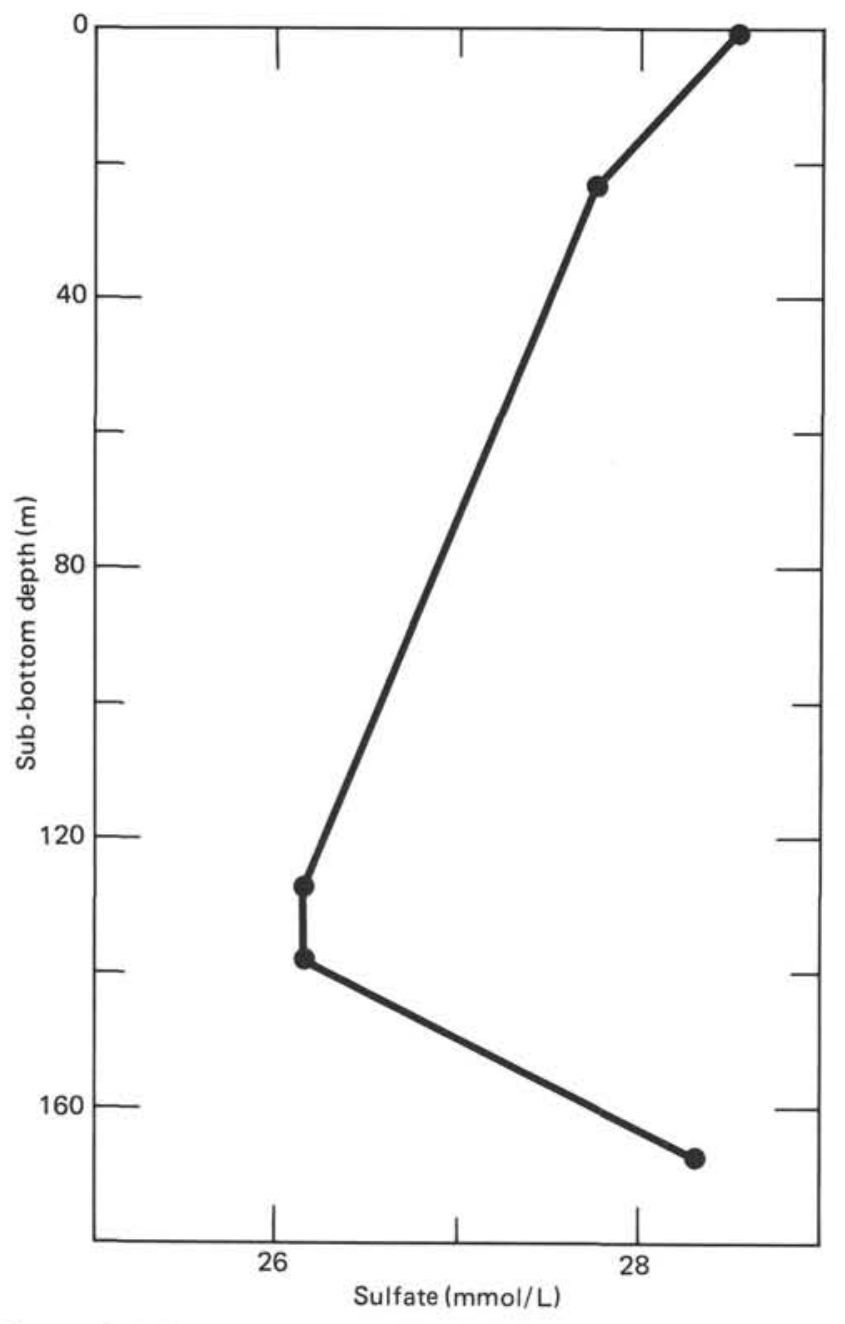

Figure 12. Sulfate vs. depth plot, Hole 626D.

mixing with inorganic material, would have become heavy enough to sink in the water column and join the depositional cycle.

\section{Provenance of the Asphalt}

Without gas-chromatography-mass-spectrometry studies of the asphalt's cycloalkane fraction, a comparative study of possible oil precursors could not be made. However, Site 626 is near the South Florida Basin, which contains the Sunniland oil fields.
Table 4. X-ray analyses of samples from Hole $626 \mathrm{C}$.

\begin{tabular}{lcccccc}
\hline & \multicolumn{3}{c}{ Minerals } & & \multicolumn{2}{c}{ Composition } \\
\cline { 2 - 4 } \multicolumn{1}{c}{ Sample } & $\begin{array}{c}\text { Aragonite } \\
(\%)\end{array}$ & $\begin{array}{c}\text { Calcite } \\
(\%)\end{array}$ & $\begin{array}{c}\text { Dolomite } \\
(\%)\end{array}$ & & $\begin{array}{c}\mathrm{CaCO}_{3} \\
(\%)\end{array}$ & $\begin{array}{c}\mathrm{MgCO}_{3} \\
(\%)\end{array}$ \\
\hline $626 \mathrm{C}-6 \mathrm{X}$ & $\mathrm{Tr}$ & 100 & 0 & & $\sim 99$ & 0 \\
$626 \mathrm{C}-13 \mathrm{H}, \mathrm{CC}$ & 0 & 100 & 0 & & $\sim 99$ & 0 \\
$626 \mathrm{C}-14 \mathrm{H}$ & 0 & 100 & $\mathrm{Tr}$ & & $\mathrm{a}_{60}$ & $\mathrm{a}_{40}$ \\
$626 \mathrm{C}-15 \mathrm{H}$ & 0 & 99 & 1 & & $\mathrm{a}_{55}$ & $\mathrm{a}_{45}$ \\
$626 \mathrm{C}-18 \mathrm{H}$ & 25 & 75 & 0 & & $\sim 99$ & 0 \\
\hline
\end{tabular}

${ }^{\text {a }}$ Dolomite only.

If these asphalt clasts are of Sunniland oil provenance, then a tentative date for the start of oil generation in the South Florida Basin would be early Miocene at the latest.

\section{PALEOMAGNETISM}

\section{Natural Remanent Magnetization}

Thirty-four oriented paleomagnetic samples were obtained from cores recovered from Site 626. Two of these samples, consisting of carbonate sand, were taken from Core $5 \mathrm{~W}$ of Hole 626B. The remainder were taken from calcareous sand, silt, and mud from Hole $626 \mathrm{C}$. Most of the samples have magnetic moments less than $8 \times 10^{-7}$ emu and thus cannot be accurately measured on the Molspin spinner magnetometer in the shipboard paleomagnetic laboratory. Whether or not useful paleomagnetic data can be gleaned from the samples is a question that must await their measurement in a more sensitive cryogenic magnetometer.

The two samples from Core 626B-5W and five samples from Core $626 \mathrm{C}-4 \mathrm{X}$ are a notable exception. They have much higher magnetizations, ranging from $9.6 \times 10^{-5}$ to $5.1 \times 10^{-4} \mathrm{emu}$. Their common trait is that they are samples of foraminiferal sand in which there is a significant amount of authigenic glauconite and pyrite, both iron-bearing minerals. Interestingly, four of the five samples from Core $626 \mathrm{C}-4 \mathrm{X}$ are reversely magnetized. Although it is believed that the sand contained in Core $626 \mathrm{C}-4 \mathrm{X}$ was reworked by the drilling process (see "Sedimentology," this chapter), the reversed magnetizations are most easily explained by assuming that the material was instead recovered with little disturbance. If this sand had been suspended in water and then allowed to settle out in the present geomagnetic field, a normal magnetization should have occurred.

\section{Magnetic Susceptibility}

Volume magnetic-susceptibility measurements were made on cores from Site 626 using a Bartington Instruments Model MS-1 


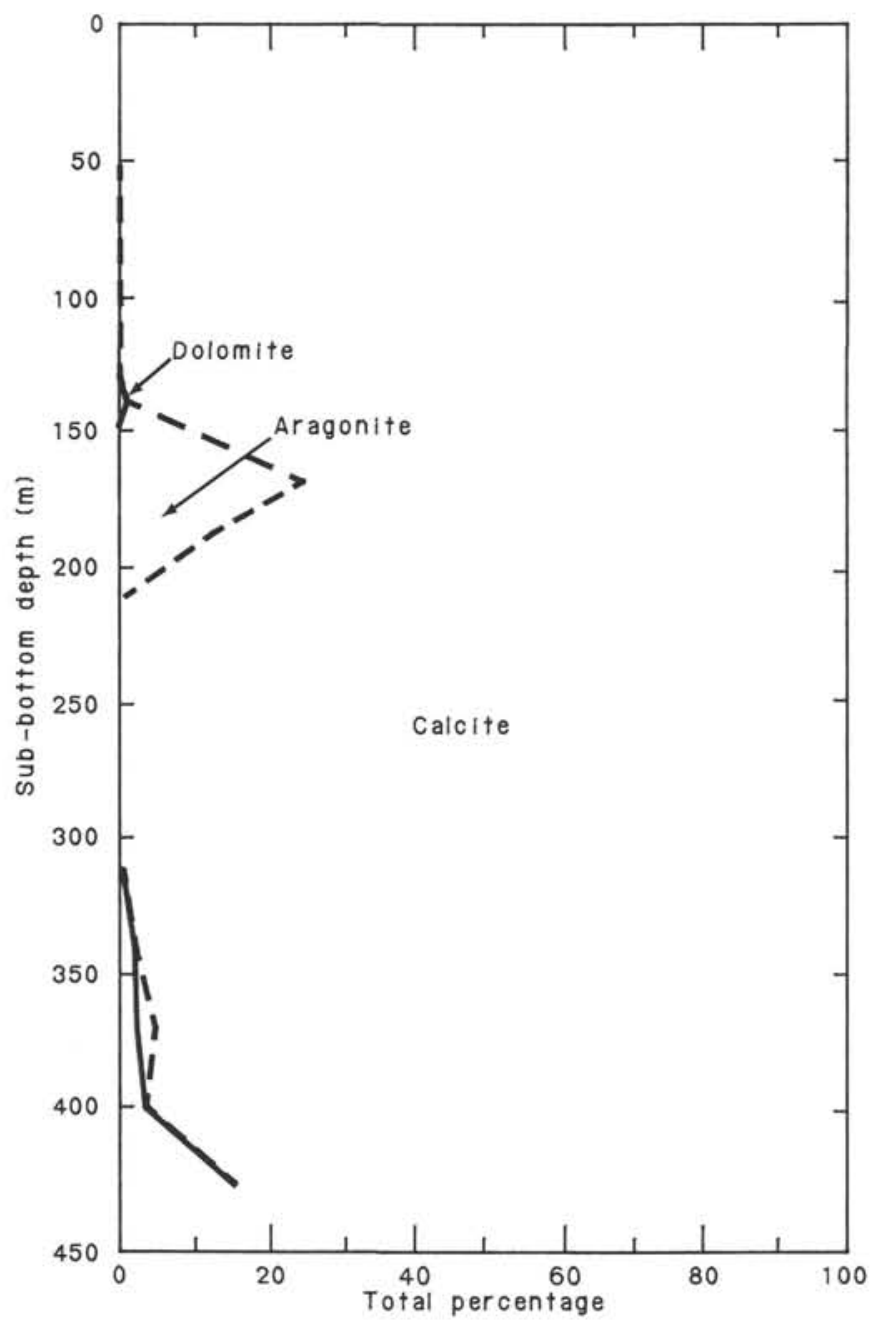

Figure 13. X-ray data, Site 626.

Table 5. Carbonate-bomb data, Site 626.

\begin{tabular}{cr}
\hline $\begin{array}{c}\text { Sub-bottom depth } \\
(\mathrm{m})\end{array}$ & $\begin{array}{r}\mathrm{CaCO}_{3} \text { content } \\
(\%)\end{array}$ \\
\hline 3.6 & 100 \\
18.7 & 96 \\
85.2 & 92 \\
123.9 & 93 \\
126.9 & 97 \\
129.9 & 93 \\
133.5 & 98 \\
136.5 & 97 \\
139.5 & 93 \\
143.0 & 96 \\
146.0 & 93 \\
148.1 & 100 \\
149.4 & 91 \\
149.5 & 100 \\
152.6 & 97 \\
155.6 & 90 \\
158.6 & 99 \\
165.2 & 90 \\
168.2 & 90 \\
276.6 & 96 \\
293.9 & 95 \\
303.6 & 94 \\
370.4 & 94 \\
429.9 & 100 \\
\hline &
\end{tabular}

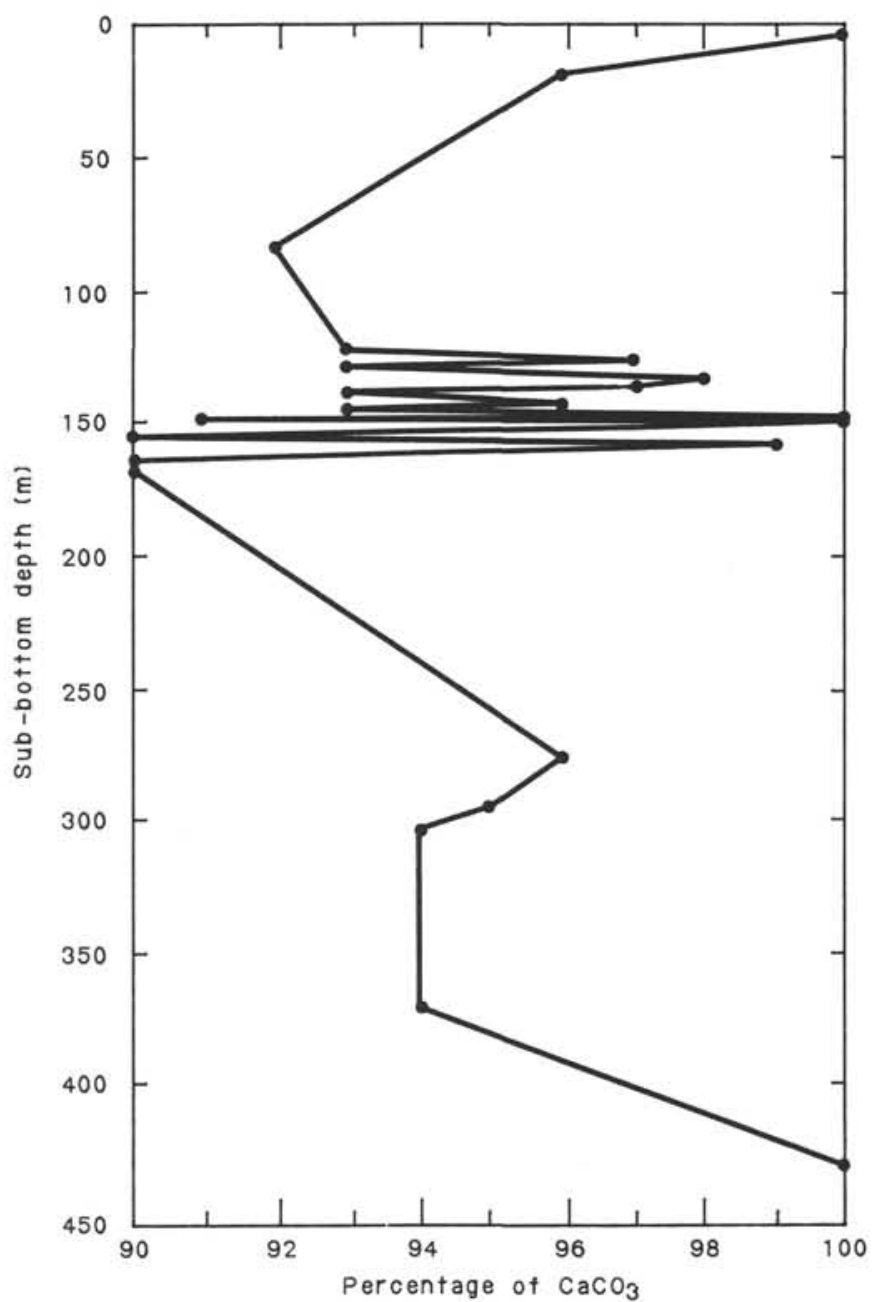

Figure 14. Carbonate-bomb data, Site 626.

susceptibility meter with a 100 -mm sensor coil through which whole cores could be passed. Measurements were taken at $10-\mathrm{cm}$ intervals, from top to bottom, of each 1.5 -m core section before it was split. Susceptibility readings were taken from 1 core from Hole 626A, 3 from $626 \mathrm{~B}$, and 10 from $626 \mathrm{C}$. No measurements were made on cores from Hole $626 \mathrm{D}$, as these consisted mainly of samples of long, washed intervals that were unlikely to give any reliable stratigraphic information. The susceptibility values and core mean values are plotted versus depth in Figure 15.

For reference, an empty core liner and one full of seawater were measured. As expected, the susceptibility of the empty liner was undetectable, but the seawater displayed a weak diamagnetism (i.e., negative susceptibility), registering a value of -0.4 $\times 10^{-6}$ gauss/oersted (G/Oe). As calcium carbonate has a diamagnetic susceptibility similar to that of water (Collinson, 1983), negative susceptibility values are taken as an indication that the cored material contains very little other than water and carbonate. Conversely, cores giving positive susceptibility readings are assumed here, as elsewhere (e.g., Radhakrishnamurty et al., 1972; Ellwood, 1980), to indicate the presence of minute amounts of iron-bearing minerals.

The few cores measured from Holes 626A and 626B all showed either diamagnetism or weak paramagnetism generally ranging from $-0.4 \times 10^{-6}$ to $9.3 \times 10^{-6} \mathrm{G} / \mathrm{Oe}$. One reading of $186.2 \times 10^{-6} \mathrm{G} / \mathrm{Oe}$ was obtained (Core 626B-4R) owing to the inclusion in the sediment of a fragment from the drill pipe. 
Table 6. Organic-geochemical (Rock-Eval) values, Site 626.

\begin{tabular}{|c|c|c|c|c|c|c|}
\hline $\begin{array}{c}\text { Sample } \\
\text { (levels in } \mathrm{cm} \text { ) }\end{array}$ & $\mathrm{S}_{1}$ & $S_{2}$ & $\mathrm{~S}_{3}$ & $\begin{array}{l}\mathrm{T}_{\max } \\
\left({ }^{\circ} \mathrm{C}\right)\end{array}$ & $\frac{\text { Production index }}{S_{1} /\left(S_{1}+S_{2}\right)}$ & $\mathrm{S}_{2} / \mathrm{S}_{3}$ \\
\hline $626 \mathrm{C}-4 \mathrm{X}-1,32-41$ & 0.20 & 0.34 & 1.01 & 378 & 0.37 & 0.34 \\
\hline $626 \mathrm{C}-6 \mathrm{X}-1,101-110$ & 0.14 & 0.12 & 1.20 & 395 & 0.54 & 0.10 \\
\hline a $626 \mathrm{C}-6 \mathrm{X}-1,101-110$ & 0.77 & 1.65 & 2.91 & 390 & 0.32 & 0.57 \\
\hline $626 C-9 X-1,27-38$ & 0.01 & 0.02 & 1.36 & 420 & 0.33 & 0.01 \\
\hline $626 \mathrm{C}-13 \mathrm{H}-1,41-50$ & 0.36 & 0.21 & 0.78 & 413 & 0.63 & 0.27 \\
\hline $626 \mathrm{C}-15 \mathrm{H}-1,10-19$ & 0.20 & 0.36 & 2.07 & 390 & 0.36 & 0.17 \\
\hline 626D-1R, CC & 0.09 & 0.57 & 0.75 & 480 & 0.14 & 0.76 \\
\hline
\end{tabular}

a Acidified sample.

$\mathrm{S}_{1}<0.5=$ poor oil source; $0.5-1.0=$ fair $>1.0=$ oil show.

$\mathrm{S}_{2}>2.0=$ poor oil source.

$\mathrm{T}_{\max }<435^{\circ} \mathrm{C}=$ immature source rock.

Production index: $\mathrm{S}_{1}\left(\mathrm{~S}_{1}+\mathrm{S}_{2}\right)<0.1=$ immature; $0.1-0.4=$ oil zone; $>0.4=$ post-mature.

$\mathrm{S}_{2} / \mathrm{S}_{3}$ kerogen type $<2.5=$ gas prone; $2.5-5.0=$ mixed; $>5.0=$ oil prone.
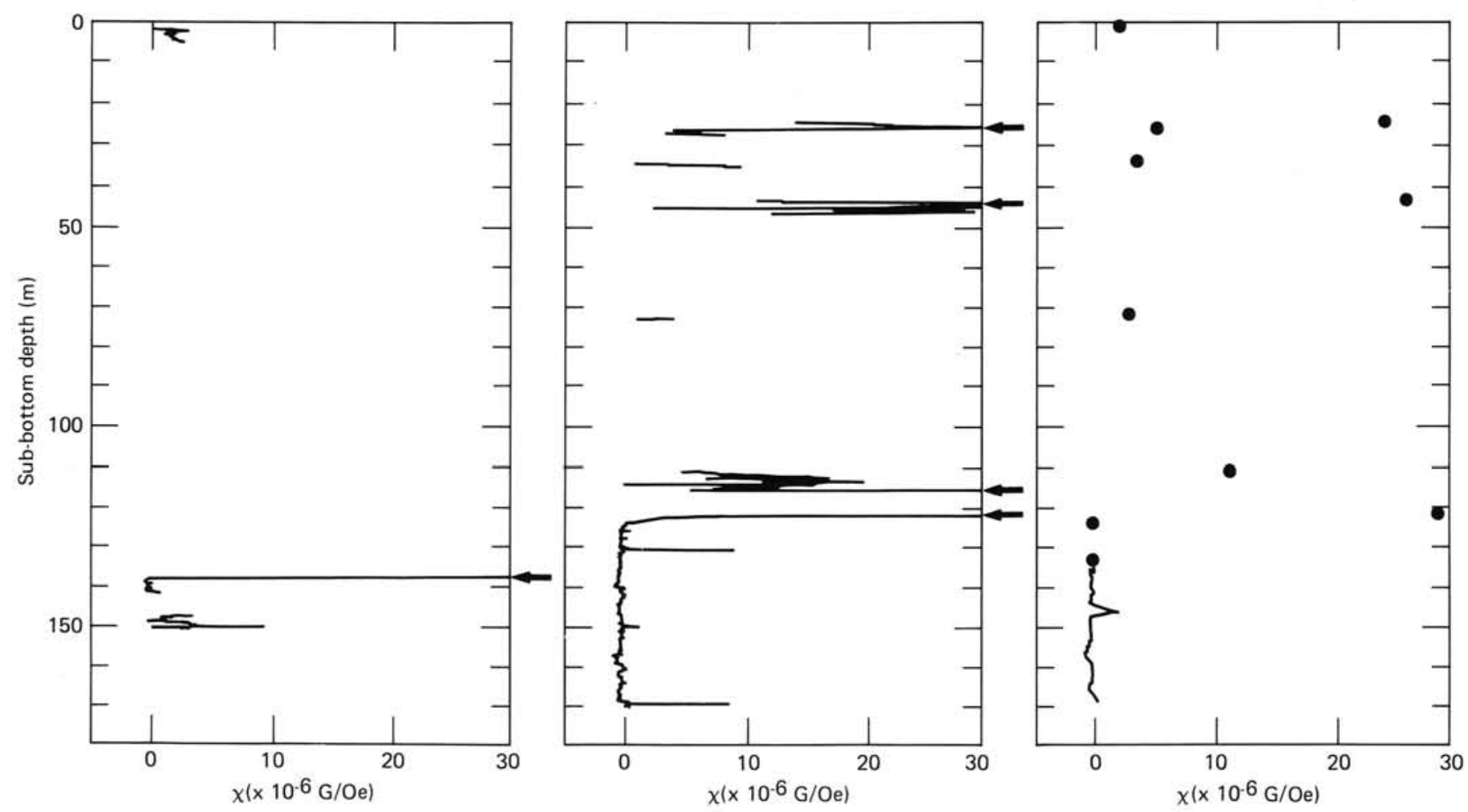

Figure 15 . Susceptibility values $\left(\times 10^{-6} \mathrm{G} / \mathrm{Oe}\right)$ plotted vs. depth in meters. At far left are the individual measurements made at 10 -cm intervals in the recovered sections of Holes $626 \mathrm{~A}$ and $626 \mathrm{~B}$. The middle plot shows the individual readings from Hole $626 \mathrm{C}$. A few large values do not fit on the graph and are sacrificed so that the smaller variations of suceptibility can be shown. At right the mean susceptibility value of each core is plotted against depth. Arrows indicate off-scale values.

A sharp dichotomy of magnetic behavior was noted in cores from Hole $626 \mathrm{C}$. Above $122 \mathrm{~m}$ sub-bottom (Core $626 \mathrm{C}-13 \mathrm{H}$ and shallower), susceptibility values tend to be positive, large, and wildly scattered (Fig. 15). Conversely, deeper cores display a weak but consistent diamagnetism. The diamagnetic results suggest that these cores contain water and calcareous material and lack magnetic minerals. The paramagnetic readings appear to correlate with two types of sediments in particular, glauconite-rich sands and coarse-grained sands appearing as downhole contamination. As noted above, the glauconite-rich sands have strong magnetic properties. The downhole contaminants, on the other hand, probably pick up a trace of metal fragments as they are ground around the upper part of the hole by the drill string.
At the top of Section $626 \mathrm{C}-14 \mathrm{H}-1$, susceptibility measurements as high as $598.8 \times 10^{-6} \mathrm{G} / \mathrm{Oe}$ were obtained. Similarly high values of susceptibility were measured in Core $626 \mathrm{C}-13 \mathrm{H}$. On examination of the split cores, both were found to contain small flakes of rusted metal. The susceptibility decreases with depth in Core $626 \mathrm{C}-14 \mathrm{H}$, but it is not until Section 3 that values typical of the succeeding cores are reached. It appears that some metal contaminates both Sections 1 and 2 . Although the dark metal fragments are visible to the naked eye in Section 1, they are not obvious in Section 2. Core $626 \mathrm{C}-13 \mathrm{H}$ and the top of Core $626 \mathrm{C}-14 \mathrm{H}$ have been interpreted as consisting partly or entirely of material that has fallen down the hole from above. It appears that such material is dislodged from the sides of the 
hole as the drill string is raised slightly during core retrieval. When coring resumes, the contaminated material is incorporated in the upper part of the core. Higher than average susceptibility values were measured in the top few centimeters of Cores $626 \mathrm{C}-15 \mathrm{H}, 626 \mathrm{C}-17 \mathrm{H}$, and $626 \mathrm{C}-19 \mathrm{H}$. Even though none of these readings approached the extremely high values measured in Core $626 \mathrm{C}-14 \mathrm{H}$, they suggest that the upper few tens of centimeters of most HPC cores may be slightly contaminated with metal as a result of the coring process.

\section{PHYSICAL PROPERTIES}

Physical-property measurements were made as described in the "Introduction and Explanatory Notes."

\section{Hole 626A}

Two rotary cores were recovered from Hole 626A. Since sediment disturbance was pervasive, only Gamma Ray Attenuation Porosity Evaluator (GRAPE) measurements were made. GRAPE-measured density averaged 1.9 to $2.0 \mathrm{~g} / \mathrm{cm}^{3}$.

\section{Hole 626B}

Three wash cores and two rotary cores were recovered from Hole 626B. Recovery was poor, and considerable sediment disturbance was evident. Although water and air pockets were present, GRAPE data were collected from all five cores. Average GRAPE density ranged from 1.85 to $2 \mathrm{~g} / \mathrm{cm}^{3}$. Porosity calculated from GRAPE data, assuming calcareous sediment, is $45 \%$.

Thermal-conductivity measurements made of Cores 626B-4R and 626B-5W averaged $29.69 \mathrm{cal} \times{ }^{\circ} \mathrm{C}^{-1} \times \mathrm{cm}^{-1} \times \mathrm{s}^{-1}$.

Index-property measurements of Core $626 \mathrm{~B}-5 \mathrm{~W}$ give an average porosity of $59 \%$, an average bulk density of $1.75 \mathrm{~g} / \mathrm{cm}^{3}$, an average dry water content of $51 \%$, and an average grain density of $2.70 \mathrm{~g} / \mathrm{cm}^{3}$ (see Table 7).

\section{Hole 626C}

Nineteen cores were recovered from Hole 626C. Recovery was poor within the first 12 cores (XCB cores), and sediment disturbance was a problem. Thus, most of the physical-property data were measured from Cores $626 \mathrm{C}-13$ through $626 \mathrm{C}-18$ and are illustrated in Figure 16.

These cores contain several debris flows capped by a graded bed of rubble and sand, which is interpreted as downhole contamination (see "Sedimentology," this chapter). In the matrixrich upper part of the debris flow (120.0-150.0 m), the expected increase and decrease of the index-property values as a result of burial compaction seem to be reflected. The tendency can be seen in Figure 16 and is also shown by the data at the base and at the top of this interval (Table 7).

Below $150 \mathrm{~m}$ in the sub-bottom, the debris flow comprises larger and more abundant well-lithified clasts in a soft carbonate matrix. This heterogeneous composition is recorded by the wide variation of all the physical properties. The continuous GRAPE measurements document the changes of density between the lithified clasts and the soft matrix (Fig. 17).

Compressional wave velocities were measured at $450 \mathrm{kHz}$. Measurements were made normal to the bedding plane, because samples were too soft to permit rotation for measurement in the plane parallel to bedding. Measured values are very low, indicating a high water content and low density. The lithified clast in Core $626 \mathrm{C}-17 \mathrm{H}$ is the only exception, with a measured velocity of $2361 \mathrm{~m} / \mathrm{s}$.

\section{Hole 626D}

The high velocity $(5469 \mathrm{~m} / \mathrm{s})$ recorded from Core 626D-28R, $\mathrm{CC}$ was measured on a rock fragment of spar-cemented foraminiferal grainstone (Table 7).

Table 7. Physical properties of sediments, Site 626.

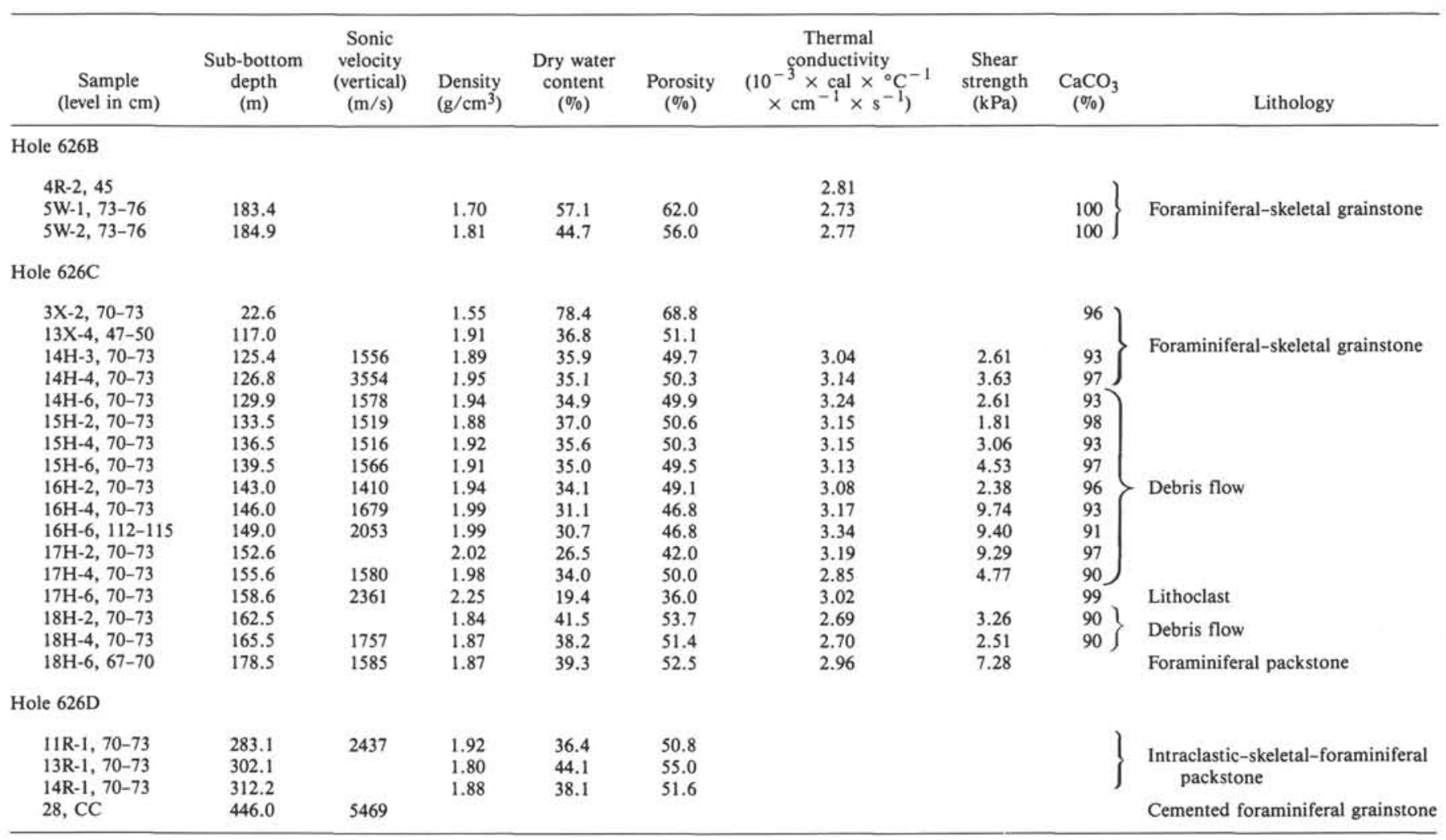




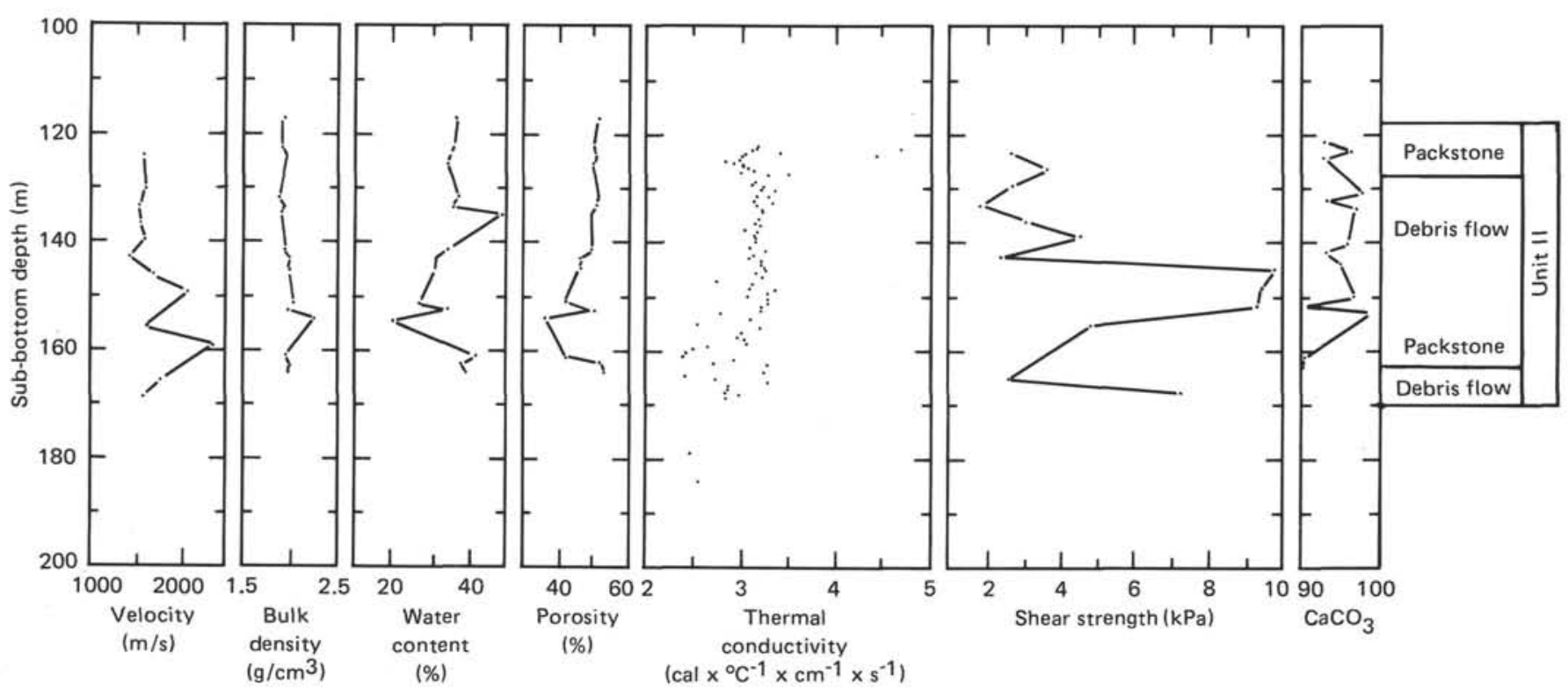

Figure 16. Graphic summary of the physical properties of lithologic Unit II from Hole 626C. Density, water content, and porosity values were determined by gravimetric and volumetric techniques.

\section{Conclusions}

For physical-property measurements such as undrained shear strength and velocity to be valid, sediment must be as close to in-situ conditions as possible. Thus, most values reported from Hole 626B and Hole 626D are best estimates, as many of the cores received were highly disturbed. The data reported from Hole $626 \mathrm{C}$ represent the best quality physical-property data from this site. These data seem to be controlled mainly by the lithologic composition of the sediment and not by burial compaction.

\section{DOWNHOLE MEASUREMENTS}

Originally, an extensive set of logging runs was planned for Hole $626 \mathrm{D}$, but the hole conditions that ensnared the drill string and forced premature abandonment of the drilling program also precluded any open-hole logging, thus eliminating almost all of the planned runs. The single logging run performed was undertaken by running a Standard Gamma Ray and Compensated Neutron Tool (CNTG) combination through the drill string while the string was still in place. The CNTG yields two measurements of formation porosity through the use of a dual detector system for both thermal ( $\phi$ th) and epithermal ( $\phi$ epi) neutron counts. In a dual detector system, two pairs of detectors are placed on either side of the neutron source, and the ratio of the near detector count rate to the far detector count rate is used as a measurement of the porosity of the formation. The gammaray tool produces a measurement of the total formation background gamma radiation.

The logs were run at depths from 0 to $345 \mathrm{~m}$ sub-bottom. The presence of iron drill pipe and surrounding seawater effectively blocked much of the formation radiation, rendering the gamma-ray curve relatively useless except for its ability to indicate the location of pipe collars. The neutron log also suffered from these adverse environmental conditions, but judicious comparison with both recorded drilling rates and physical-property measurements made possible a qualitative correlation with the lithologic data.

\section{Log Characterization}

The neutron curves displayed in Figure 18 show three types of response to formation conditions. First, in zones extending from 130 to $183 \mathrm{~m}$ sub-bottom and 220 to $290 \mathrm{~m}$ sub-bottom, the thermal and epithermal porosities agree closely and yield values that average between $40 \%$ and $50 \%$. Second, in zones extending from 20 to $50 \mathrm{~m}$ sub-bottom, 77 to $130 \mathrm{~m}$ sub-bottom, and 183 to $220 \mathrm{~m}$ sub-bottom, the curves separate, with the epithermal porosity averaging about $70 \%$ and the thermal porosity averaging about $55 \%$ to $60 \%$. Third, in zones extending from 50 to $77 \mathrm{~m}$ sub-bottom and 290 to $345 \mathrm{~m}$ sub-bottom, the epithermal porosity decreases dramatically in value to a near-zero average punctuated by numerous peaks reading over $25 \%$.

\section{Interpretation}

According to the lithologic data available from Holes $626 \mathrm{C}$ and $626 \mathrm{D}$, the top of a large debris flow appears between 120 and $125 \mathrm{~m}$ sub-bottom, developing into a flow of lithified clasts in a soft packstone matrix by $130 \mathrm{~m}$ sub-bottom. This flow is clearly reflected in the neutron log by the appearance of one of the low-porosity zones (130 to $183 \mathrm{~m}$ sub-bottom). The section of graded gravel may be reflected in the log by the appearance of a continuous decrease in porosity from 119 to $122 \mathrm{~m}$ sub-bottom, as GRAPE measurements of the gravel section reveal a small but noticeable increase in density (decrease in porosity) with depth (see "Physical Properties" section, this chapter).

The second low-porosity zone ( 220 to $290 \mathrm{~m}$ sub-bottom) develops in a section of poor core recovery, but records of drilling speed indicate that a hard layer exists in the same interval. It naturally follows that harder carbonate material would exhibit lower porosity. The curves in this zone also exhibit a number of abrupt peaks and dips; these small-scale variations may be either a reflection of alternating hard and soft layers or an indication of variable borehole diameter.

In general, the three zones of higher porosity ( 20 to $50 \mathrm{~m}, 77$ to $130 \mathrm{~m}$, and 183 to $220 \mathrm{~m}$ sub-bottom) correspond to layers of soft skeletal grainstone-packstone, which can be characterized in general terms as muddy sand. In addition to exhibiting higher 


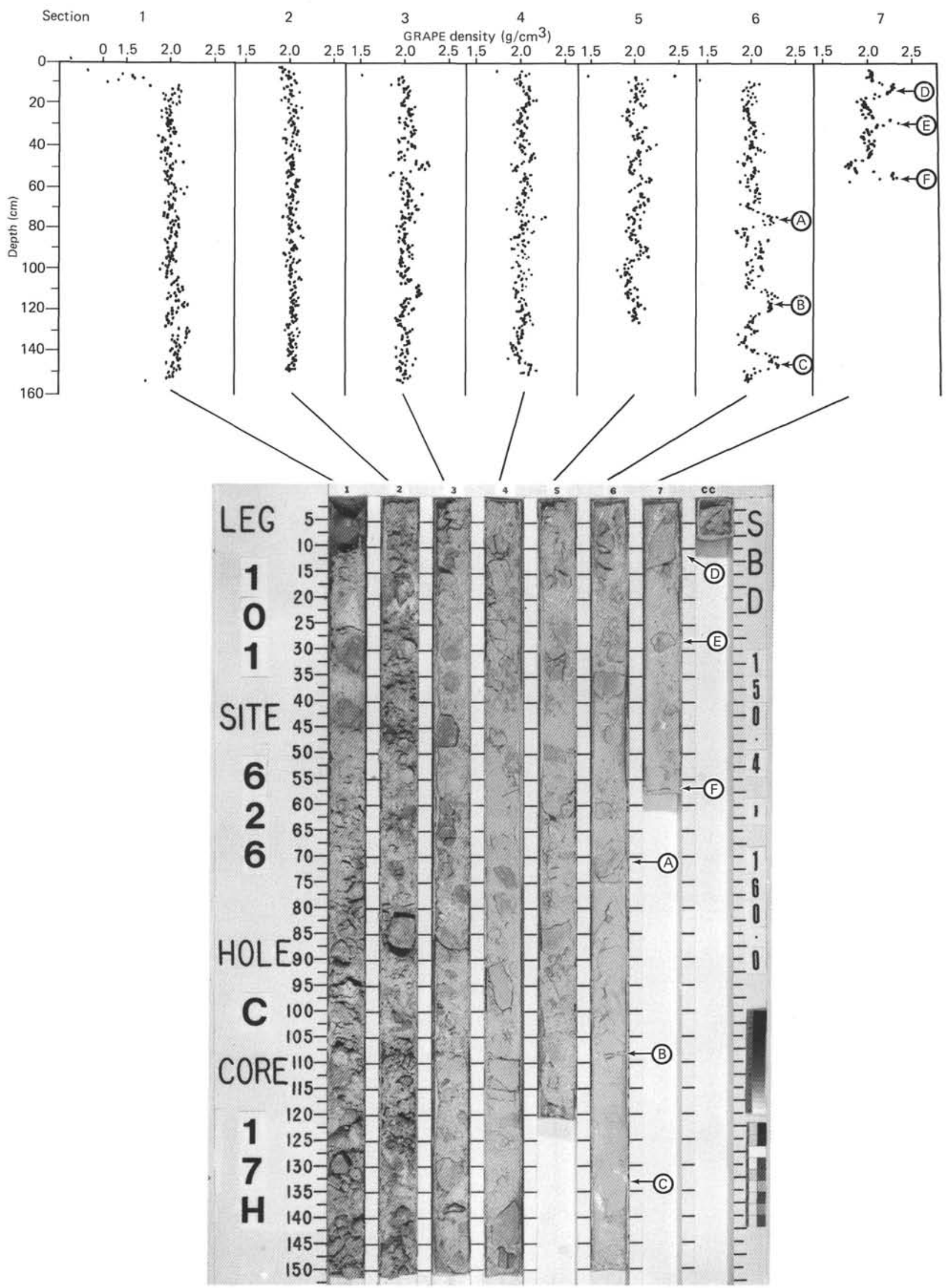

Figure 17. The continuous density log made by GRAPE on Core $626 \mathrm{C}-17$ documents the changes of density between the lithified clasts (indicated by the letters $A$ through $F$ ) and the soft matrix at the base of the debris flow. 

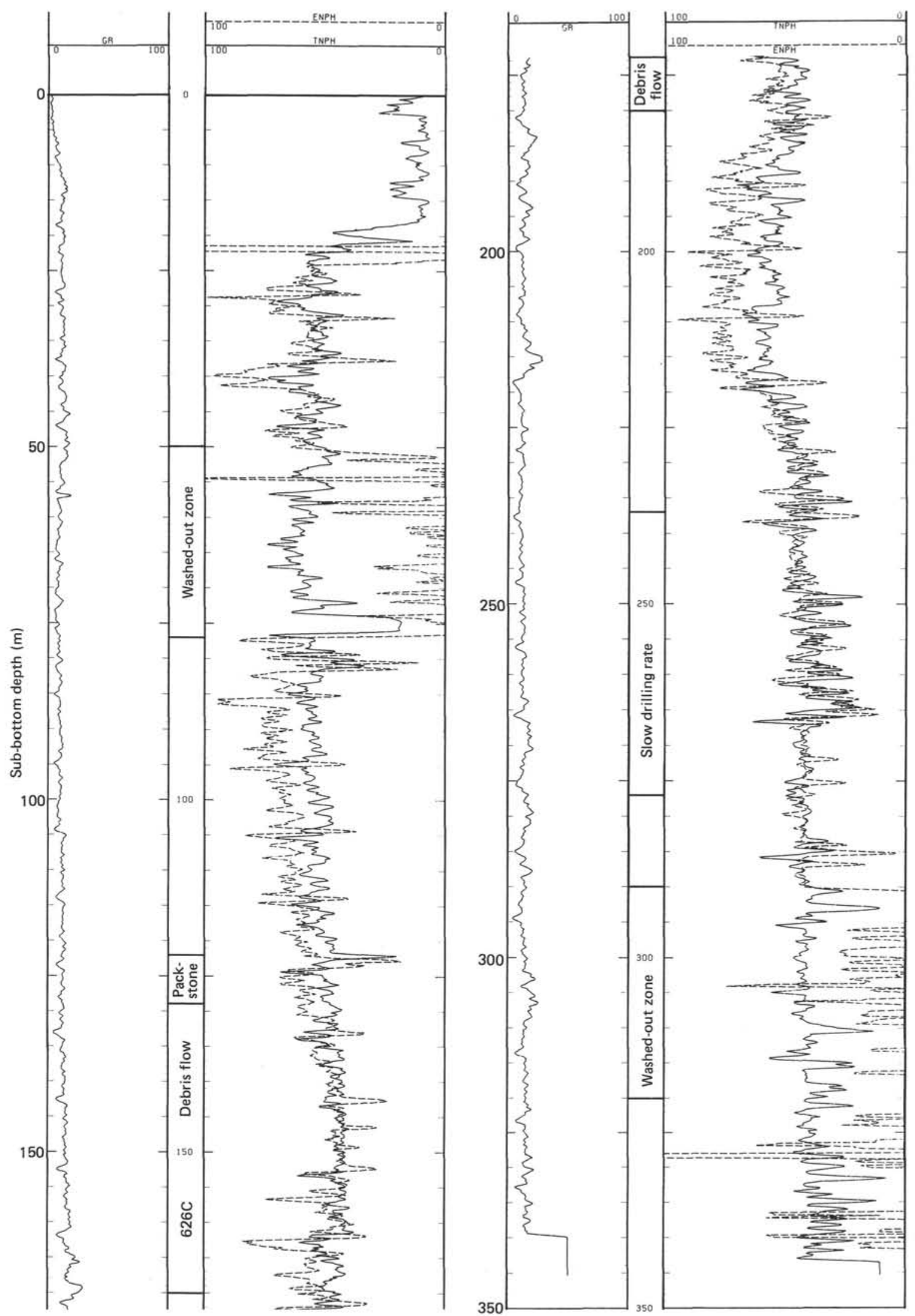

Figure 18. Neutron porosity and gamma-ray logs from Hole 626D, with prominent lithologies from Hole $626 \mathrm{C}$ indicated. ENPH stands for epithermal porosity, and $T N P H$ for thermal porosity. Natural gamma radiation is given in standard API units. 
porosities, these soft layers may correspond to larger hole diameters, as they are more easily disturbed by drilling. This possibility is reflected by the higher porosity given by the epithermal curve, as the epithermal detectors are more sensitive to variable borehole size than are the thermal detectors (Davis et al., 1981). For example, a tool stand-off of 2.3 in. in an 8-in.-diameter limestone borehole leads to a positive error in the epithermal porosity curve of greater than 6 porosity units $(6 \%)$.

The zones with very low epithermal porosities developed as difficult problems in interpretion until an examination of the raw count-rate data was made. As the Schlumberger tool calculates porosity by taking the ratio of near detector to far detector count rates, a large ratio implies high porosity (short neutron slowing-down length), and a ratio near 1 implies low porosity (long slowing-down length). In these zones the epithermal counts were so low for both detectors that the ratios mistakenly indicated low porosity. The low count rates actually reflect a large amount of hydrogen, so these drops in the epithermal curve should correspond to zones that have experienced significant washout. Consequently, the porosity curves are of little value in the depth ranges from 50 to $77 \mathrm{~m}$ sub-bottom and from 290 to $345 \mathrm{~m}$ sub-bottom. As the beginning of the proposed chert layer is at $322.2 \mathrm{~m}$ sub-bottom (see "Sedimentology" section, this chapter), the logs are unable to provide any information about its existence.

\section{SEISMIC STRATIGRAPHY}

\section{Introduction}

Site 626 was the culmination of an effort that began in April 1984, when the University of Texas Institute for Geophysics (UTIG) vessel Fred $H$. Moore collected approximately $250 \mathrm{n}$. mi of 24-trace, 12-fold seismic-reflection profiles as a site-specific survey for drilling in the Straits of Florida (Fig. 4). Sonobuoys were also collected for additional velocity control.

The next step in preparing for Leg 101 took place at LamontDoherty Geological Observatory (LDGO), where semblance velocity analyses were carried out every 10 common depth points (CDP) (approximately every $180 \mathrm{~m}$ ) on all seismic lines on which a prospective Straits of Florida site had been designated: FS-02, FS-04, FS-08, FS-14, FS-17, FS-19, and FS-21 (Fig. 4). These velocities were then available for time-to-depth conversions of sequence boundaries identified within the grid.

Through the fall of 1984, all Straits of Florida lines were interpreted according to the principles set forth by Vail et al. (1977). Eleven seismic sequences above the basal velocity discontinuity were identified and mapped (see Fig. 3). Using the detailed velocity calculations, isopach and structure maps for each sequence and bounding acoustic horizon were prepared at UTIG.

\section{Site 626}

As a result of 4 drilling attempts near BAH-1-C (Holes 626A through $626 \mathrm{D}), 6$ of 11 mapped seismic sequences $(10,9,8,7$, 6 , and 5 ) and 5 (perhaps 6 ) of 11 sequence boundaries $(11 / 10$ ?, $10 / 9,9 / 8,8 / 7,7 / 6$, and $6 / 5$ ) were encountered (Fig. 3). The following is an interpretation of the physical basis for these seismic features. At the outset, it should be noted that, as a result of early dynamic-positioning problems (see "Operations Summary," this chapter), all four of the penetrations at Site 626 were approximately $1.0 \mathrm{n}$. mi north-northeast of the originally designated site position (Fig. 4, inset). Fortunately, Holes 626B, $626 \mathrm{C}$, and $626 \mathrm{D}$ were located within $0.25 \mathrm{n}$. mi of FS-08, CDP 700 , which also happened to be the crossing of that seismic line with LDGO multichannel seismic profile 92 (Fig. 4; Sheridan et al., 1981). A comparison of the Site 626 correlations with line 92 is made at the end of this discussion.

\section{Hole 626A}

Hole $626 \mathrm{~A}$ penetrated only $12.8 \mathrm{~m}$ of lime rubble and sand, which translates to less than $0.02 \mathrm{~s}$ of travel time below water bottom at the water velocity characteristic of sequence 10 (Fig. 3 and Table 8). No sequence boundaries could be resolved at this depth with the site-survey profiles. The fact that spud in could not be completed at Hole $626 \mathrm{~A}$ was ultimately fortunate from the standpoint of seismic correlation, because Holes 626B, $626 \mathrm{C}$, and $626 \mathrm{D}$ were all close to each other and closer to seismic control than was Hole 626A (Fig. 4, inset).

\section{Holes 626B Through 626D}

\section{Introduction}

Holes 626B through 626D lie approximately $0.25 \mathrm{n}$. mi east of line FS-08, CDP 700 (Fig. 19). In order to make an indirect assessment of the local depth variation of pertinent sequence boundaries across that gap, their depths were calculated at points $0.25 \mathrm{n}$. mi along FS-08 in both directions from point 700 (CDP 675 and CDP 725, Fig. 19). Those results are tabulated below (depths are sub-bottom):

\begin{tabular}{|c|c|c|}
\hline $\begin{array}{l}\text { Sequence } \\
\text { boundary }\end{array}$ & $\begin{array}{l}\text { CDP } 700 \\
\text { depth }\end{array}$ & $\begin{array}{l}\text { CDP } 675-725 \\
\text { depth range }\end{array}$ \\
\hline $10 / 9$ & $88 \mathrm{~m}$ & $86-90 \mathrm{~m}$ \\
\hline $9 / 8$ & $187 \mathrm{~m}$ & $164-187 \mathrm{~m}$ \\
\hline $8 / 7$ & $213 \mathrm{~m}$ & $206-213 \mathrm{~m}$ \\
\hline $7 / 6$ & $334 \mathrm{~m}$ & $327-342 \mathrm{~m}$ \\
\hline $6 / 5$ & $360 \mathrm{~m}$ & $359-374 \mathrm{~m}$ \\
\hline
\end{tabular}

\section{Hole $626 B$}

Hole 626B penetrated $185.5 \mathrm{~m}$ sub-bottom. Recovery was only $8 \%$ because most of the section was washed. Core $626 \mathrm{~B}-4 \mathrm{R}$ did recover $73 \%$ of the interval between 137.7 and $147.3 \mathrm{~m}$ sub-bottom, and this section was tied to Samples $626 \mathrm{C}-16 \mathrm{H}-1$ through $5,0-40 \mathrm{~cm}$, but both the $10 / 9$ and $9 / 8$ sequence boundaries are contained within washed intervals. However, based on the nannofossil and foraminifer dates obtained for Core 626B-1W ( $80.27 \mathrm{~m}$ sub-bottom), all of the sequence boundaries listed above must be older than late Miocene-early Pliocene.

\section{Holes $626 \mathrm{C}$ and $626 \mathrm{D}$}

By means of XCB and HPC techniques, Hole 626C sampled to $179.3 \mathrm{~m}$ sub-bottom with an overall recovery of $37 \%$. The $\mathrm{XCB}$ (Cores $626 \mathrm{C}-1 \mathrm{X}$ through $626 \mathrm{C}-12 \mathrm{X}$ ) recovered $11 \%$ to $112.1 \mathrm{~m}$ sub-bottom, whereas the HPC recovered $80 \%$ of the interval from 112.1 to $179.3 \mathrm{~m}$ sub-bottom. As a complement to Hole $626 \mathrm{C}$, Hole $626 \mathrm{D}$ was washed to $179.4 \mathrm{~m}$ sub-bottom, where continuous rotary coring began and continued to $446.8 \mathrm{~m}$ sub-bottom. Unfortunately, recovery in this cored interval was only $3 \%$, but the two holes together provide the best stratigraphic record available from Site 626 for comparison with the regional seismic data.

Three lithologic units were recognized ("Sedimentology" section, this chapter). Within Unit I, an alternating sequence of skeletal grainstones and packstones, only two depositional breaks can be documented. The first separates lower Pliocene (Core 626C-7X) from lower Pleistocene (Core 626C-6X) sediments between 54.3 and $63.9 \mathrm{~m}$ sub-bottom. The $11 / 10$ sequence boundary could not be recognized in the vicinity of BAH-1-C because of poor near-bottom resolution and/or erosion, but we tentatively correlate $11 / 10$ with the early Pliocene-early Pleistocene hiatus.

The second break within Unit I occurs between $83.0 \mathrm{~m}$ subbottom (Core 626C-9X) and $102.4 \mathrm{~m}$ sub-bottom (Core 626C- 
Table 8. Seismic stratigraphy and velocity structure of site-survey profile FS-08 at its closest point of approach to Holes 626B, 626C, and 626D.

\begin{tabular}{cccccc}
\hline Sequence & $\begin{array}{c}\text { Sequence } \\
\text { boundary }\end{array}$ & $\begin{array}{c}\text { Depth below } \\
\text { sea level }(\mathrm{m})\end{array}$ & $\begin{array}{c}\text { Sequence } \\
\text { thickness } \\
(\mathrm{m})\end{array}$ & $\begin{array}{c}\text { Cumulative thickness: } \\
\text { sub-bottom depth } \\
(\mathrm{m})\end{array}$ & $\begin{array}{c}\text { Sequence velocity } \\
(\mathrm{km} / \mathrm{s})\end{array}$ \\
\hline 10 & $10 / 9$ & 939 & 88 & 88 & 1.5 \\
9 & $9 / 8$ & 1038 & 99 & 187 & $1.98 \pm 0.05$ \\
8 & $8 / 7$ & 1064 & 26 & 213 & $2.11 \pm 0.02$ \\
7 & $7 / 6$ & 1185 & 121 & 334 & $2.11 \pm 0.02$ \\
6 & $6 / 5$ & 1211 & 26 & 360 & $2.11 \pm 0.02$ \\
5 & $5 / 4$ & 1313 & 102 & 462 & $2.11 \pm 0.02$ \\
\hline
\end{tabular}

Water depth $=851 \mathrm{~m}$ (multichannel seismics), $839(3.5 \mathrm{kHz})$; total depth $=447 \mathrm{~m}$ sub-bottom; total sediment thickness to original target $=1213 \mathrm{~m}$; total depth below sea level to original target $=2064 \mathrm{~m}$.

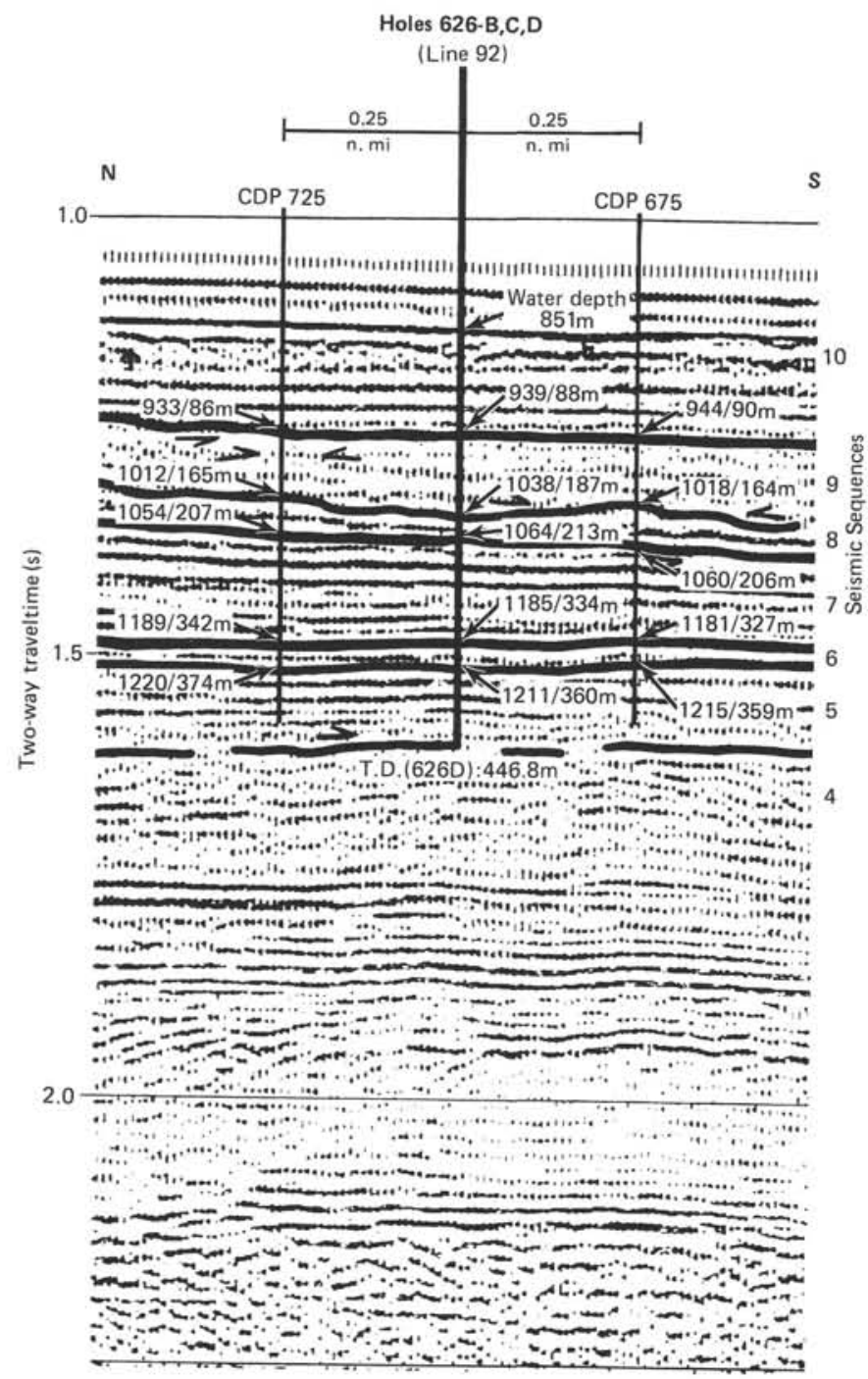

Figure 19. Portion of multichannel seismic line FS-08 (see Fig. 3) closest to Holes 626B, 626C, and 626D. CDP 700 is the calculated point of closest approach, $\sim 0.25 \mathrm{n}$. mi.
$11 \mathrm{X}$ ). It coincides both with a shift in faunal assemblages (from middle Miocene to upper Miocene) and a change in depositional rates ("Sediment-Accumulation Rates," this chapter). This hiatus was tied to the $10 / 9$ sequence boundary.

Unit II (121.7 to $169.6 \mathrm{~m}$ sub-bottom) is composed of gravity-flow deposits, implying rapid, episodic deposition. Biostratigraphic evidence suggests a constant age throughout Unit II. The only break in this pattern is noted when the earliest middle Miocene age obtained from Core $626 \mathrm{C}-19 \mathrm{H}, \mathrm{CC}(179.3 \mathrm{~m}$ subbottom) is compared with the middle Miocene or slightly older age from Core 626D-1R (189.0 m sub-bottom), suggesting either significant downhole contamination in Core $626 \mathrm{D}-1 \mathrm{R}$ or at least $9.7 \mathrm{~m}$ of depositional relief. If the section immediately underlying the debris flows had been disturbed by their emplacement, some mixing of faunas could be explained, perhaps partially resolving the biostratigraphic complexity. By correlating the $9 / 8$ sequence boundary (Table 8 ) with the base of the oldest debris flow at $169.6 \mathrm{~m}$ sub-bottom, erosion of the underlying sequence is suggested. First, its calculated depth range correlates with the base of the flow sequence. Second, $9 / 8$ displays $23 \mathrm{~m}$ of relief over $0.25 \mathrm{n}$. mi, more than any other sequence boundary encountered at Site 626 (Table 8), thereby indicating its erosional nature. Furthermore, the map of the depth to this surface (Fig. 20) indicates relief of more than $200 \mathrm{~m}$ over the 400 $\mathrm{mi}^{2}$ covered by the site-survey grid. Finally, by making $9 / 8$ the base of the flows, the acoustic sequence between $9 / 8$ and 10/9 must correlate with the flows themselves, and these sediments would indeed be expected to produce the observed seismic facies: hummocky, with little internal reflector continuity.

Correlating sequence boundaries within Unit III (169.6 to $446.8 \mathrm{~m}$ sub-bottom) becomes more problematic because of the poor recovery in this interval in Hole 626D. The entire unit is composed of unlithified intraclastic-skeletal-foraminiferal packstone alternating with lithified foraminiferal/foraminiferal-skeletal packstone and grainstone, including some cemented shallow-water-platform debris. The interval velocity for Unit III is $2.11 \mathrm{~km} / \mathrm{s}$ at FS-08, CDP 700 (Table 8), but we recovered numerous limestone fragments with compressional wave velocities of 2.0 to $2.4 \mathrm{~km} / \mathrm{s}$ (Hamilton Frame measurements). One sample of lithified, spar-cemented limestone at the base of Core $626 \mathrm{D}-28 \mathrm{R}$ yielded a velocity greater than $5 \mathrm{~km} / \mathrm{s}$, so an alternation of hard and soft layers seems likely for this part of the section. This would also explain the acoustic response of Unit III: high-amplitude, parallel, continuous reflectors (seismic sequences 5 through 8; Table 8). 


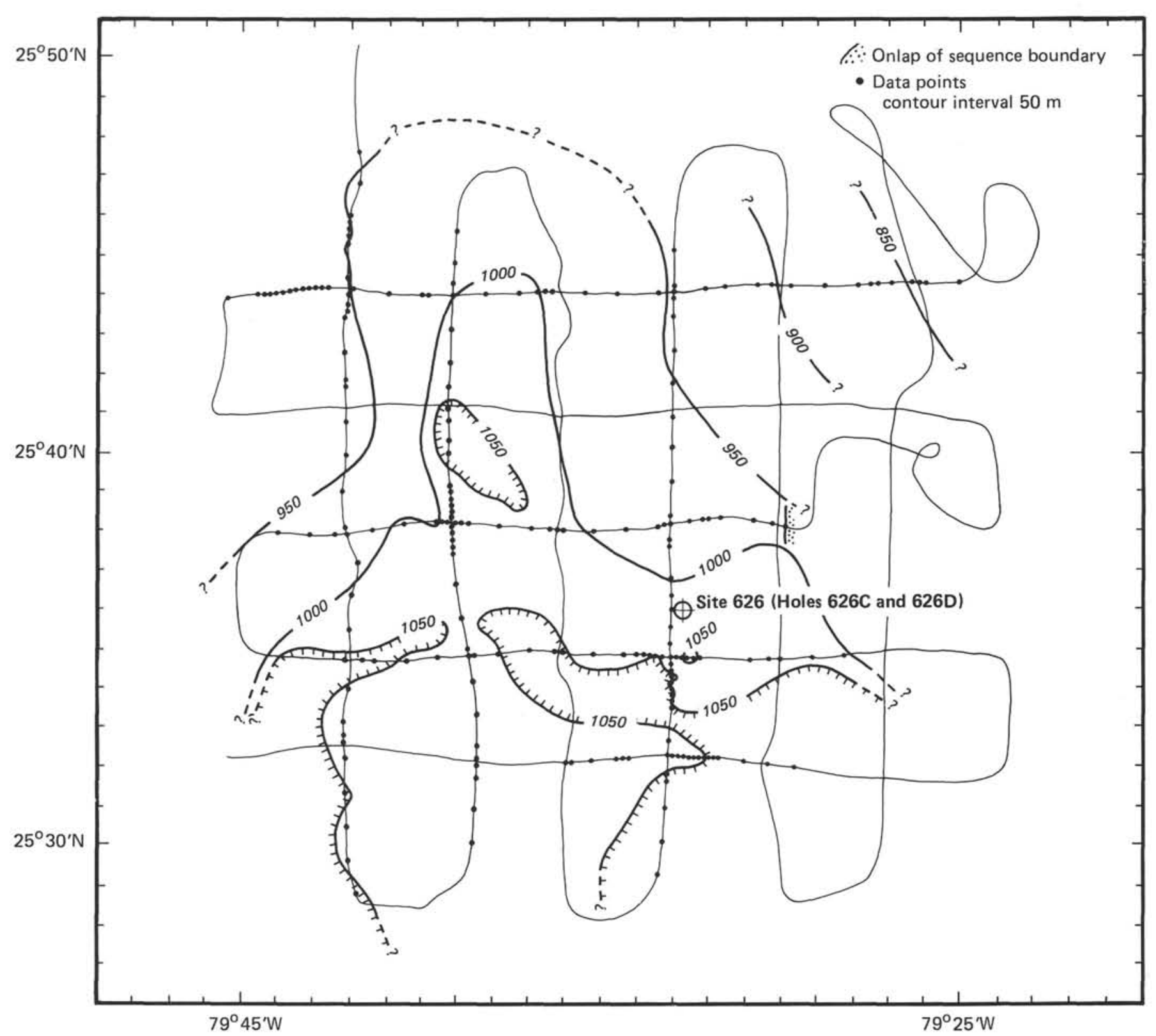

Figure 20. Structure map of seismic-sequence boundary $9 / 8$, interpreted as the base of the middle Miocene debris flows sampled at Site 626 .

Neither lithology nor biostratigraphy allows any correlation with the $8 / 7$ sequence boundary. Based on its calculated depth on FS-08, this acoustic horizon should have been encountered in Core $626 \mathrm{D}-4 \mathrm{R}$, but only a core-catcher sample was recovered and no biostratigraphic gap is evident. However, the neutron log shows a pronounced decrease in formation porosity (from $75 \%$ $80 \%$ to $55 \%$ ) in the interval $210-230 \mathrm{~m}$ sub-bottom ("Downhole Measurements," this chapter), and this suggests a concomitant density increase and perhaps the impedance contrast that produces $8 / 7$. If that is the case, $8 / 7$ must be early to middle Miocene in age.

Both the recovery of limestone and chert fragments in Cores 626D-16R, 626D-17R, 626D-19R, 626D-20R, and 626D-27R and a decrease in drilling rates ("Summary and Conclusions," this chapter) suggest that the interval from 327.4 to $370.4 \mathrm{~m}$ sub-bottom in Hole 626D is partly lithified. Both the 7/6 (327-342 m sub-bottom) and 6/5 (356-382 $\mathrm{m}$ sub-bottom) sequence boundaries fall in this range, suggesting that both acoustic horizons correlate with the presence of lithified limestones-packstonesgrainstones in an otherwise soft sequence of contourite sediments. However, the fact that both $7 / 6$ and $6 / 5$ are correlative as sequence boundaries over $400 \mathrm{n} . \mathrm{mi}^{2}$ of the subsurface of the Straits of Florida argues for their primary character, i.e., as unconformities, perhaps as surficial hardgrounds, and against a purely diagenetic origin through subsurface cementation.

In summary, 5 (and perhaps 6 , if $11 / 10$ is included) sequence boundaries and 6 sequences were sampled at Site 626 . The available evidence suggests the following conclusions (refer to Fig. 21):

1. Sequence boundaries $11 / 10$ and $10 / 9$ correspond to a latest early Pliocene-early Pleistocene and a middle Miocene-late Miocene hiatus, respectively. This raises the question of correlation of these hiatuses with the global cycles of relative changes of sea level originally proposed by Vail et al. (1977). One of the original goals of Leg 101 was to test the applicability of Vail's cycles in carbonate environments. In the Straits of Florida, fluc- 


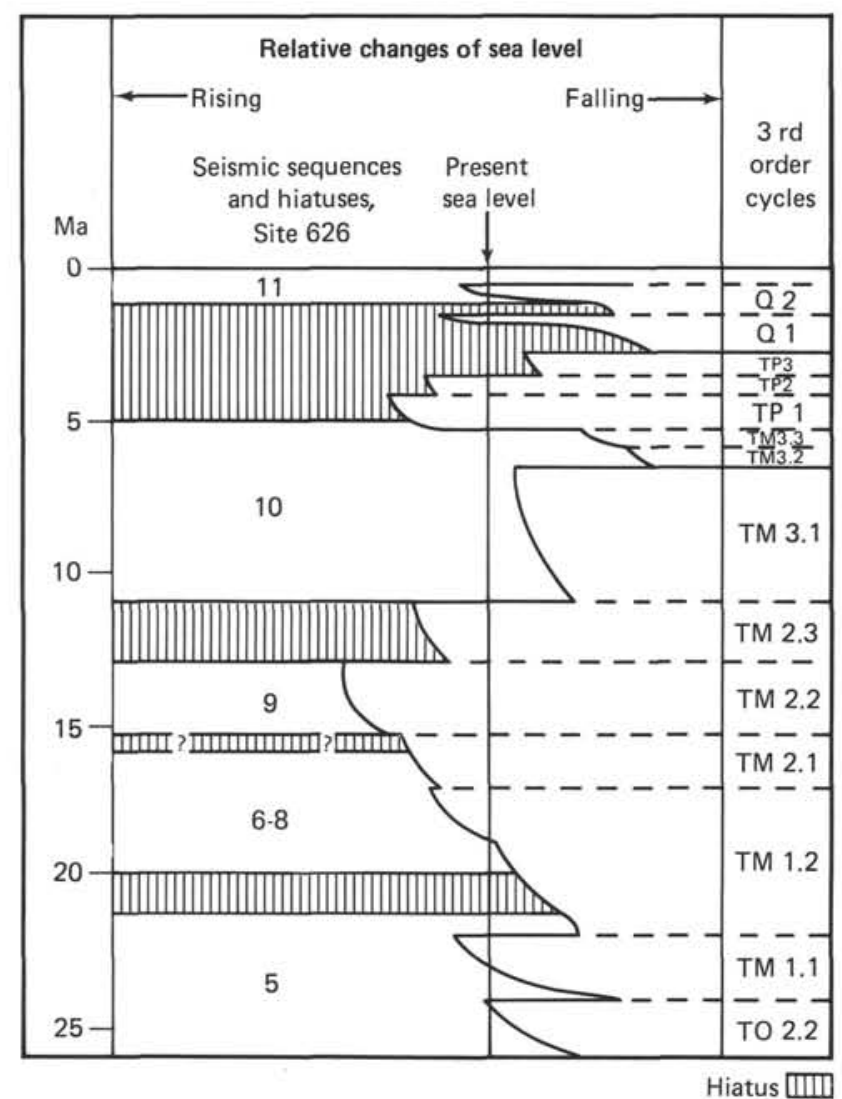

Figure 21. Hiatuses and boundaries of seismic stratigraphic sequences at Site 626 , correlated with the third-order cycles of the Vail et al. (1977) sea-level curve.

tuations in sea level should have had a direct effect on the intensity of Gulf Stream circulation, with lowstands presumably intensifying current erosion by decreasing the effective cross-sectional area of the Straits, thereby creating unconformities that should subsequently show up as seismic-sequence boundaries. This appears to be at least partly corroborated by results at Site 626. The latest early Pliocene-early Pleistocene hiatus, which is here tied to $11 / 10$, represents the interval from 5 to $15 \mathrm{Ma}$. This time interval effectively spans the TP3/Q1 cycle transition (lowstand) at $2.8 \mathrm{Ma}$ (Vail et al., 1977; Fig. 21) and marks an extended period of low sea level (Vail and Hardenbol, 1979).

2. The middle Miocene-late Miocene hiatus at Site 626 encompasses the time interval 12.1-10.2 Ma, although it could be longer. Therefore, erosion at sequence boundary $10 / 9$ can be attributed to the TM2.3/TM3.1 lowstand at $9.8 \mathrm{Ma}$ within Vail et al.'s (1977) supercycle Tc and Vail and Hardenbol's (1979) supercycle Te.

3. Sequence boundary $9 / 8$ ties to the base of a series of middle Miocene debris flows. These flows are a prevalent feature of the middle Miocene section in the western North Atlantic region ("Sedimentology" section, this chapter), but their cause is a mystery. At Site 626, dated material within the flows spans the time interval 15.5-13 Ma. A pronounced lowstand occurring at Vail's TM2.2/TM2.3 cycle transition at $13 \mathrm{Ma}$, perhaps acting in concert with some kind of tectonic event, could have been the generating mechanism for these extensive deposits, which incorporated older material as they traveled into the Straits. Erosion created by the passage and deposition of the flows presumably produced $9 / 8$ but left the depositional record largely intact.

4. Sequence boundary $8 / 7$ corresponds to a pronounced decrease in formation porosity in the lower to middle Miocene. We cannot ascertain anything else about this surface with the information available.

5. Boundaries $7 / 6$ and $6 / 5$ probably represent lower Miocene cherty zones-hardgrounds intercalated with an unlithified series of contourite deposits. Both horizons coincide with the extended lowstand in cycle TM1.2 of Vail et al. (1977; Fig. 21).

\section{Site $\mathbf{6 2 6}$ and LDGO Line 92}

Correlations between line 92, a large-volume air-gun profile, and the higher resolution site-survey results are not straightforward, but one preliminary conclusion is clear. The Straits of Florida sequence drilled at Site 626 is considerably younger than believed by Sheridan et al. (1981). The youngest unconformity interpreted on line 92 in the Straits is interpreted to separate the upper Eocene from the upper Oligocene section, but approximately corresponds in traveltime to the $8 / 7$ boundary, an early to middle Miocene horizon at Site 626 . Site 626 bottoms at $1.6 \mathrm{~s}$ in the upper Oligocene, while line 92 suggests that this part of the section is middle to late Eocene in age, a discrepancy of some 20 m.y.

\section{SUMMARY AND CONCLUSIONS}

Four holes were drilled at Site 626 . Two of them $(626 \mathrm{C}$ and 626D) were scientifically important. Together they penetrated $447 \mathrm{~m}$ of deep-water carbonate sediments of Pleistocene to Oligocene age ("Sedimentology" and "Biostratigraphy," this chapter). From top to bottom, the sequence consists of three major units of formation rank (Fig. 22): (1) Unit I, skeletal carbonate sands, muddy or clean, composed of planktonic foraminifers and neritic skeletal grains from the platforms, middle Miocene to Pleistocene, $122 \mathrm{~m}$; (2) Unit II, muddy lime rubble, graded rubble and sand, and muddy sand, interpreted as debris flows and turbidites with intercalations of pelagic sediment, middle Miocene, $48 \mathrm{~m}$; and (3) Unit III, skeletal carbonate sands as in Unit I with numerous intercalations of lithified layers (skeletal grainstones and packstones), late Oligocene to middle Miocene, $277 \mathrm{~m}$.

We interpret Units I and III as contourite deposits of the Gulf Stream. This current presently sweeps the drill site with bottom velocities of $20-40 \mathrm{~cm} / \mathrm{s}$ (Brooks, 1979). It has evidently existed in similar strength since the Oligocene, winnowing most of the planktonic and platform-derived carbonate mud and mixing the remaining globigerinid sands with the coarse residue of neritic turbidite material. Poor recovery makes a decision impossible both as to whether all of Units I and III are contourite deposits and what the exact proportions of planktonic and neritic material are.

Unit II interrupts the contourite record in a rather dramatic way. During an interval of 4 m.y. in the middle Miocene, debris flows and turbidites were emplaced too rapidly to be reworked by the bottom current. Unit II has the highest mud content and contains debris flows in pristine condition. Timing and inferred depositional processes of this unit closely resemble those of the coeval Abaco Member of the Bermuda Rise Formation in the western North Atlantic Ocean (Benson, Sheridan, et al., 1978; Sheridan, Gradstein, et al., 1983). Material in sediment gravity flows of Unit II points to sources on the adjacent platform, on its flanks, and on the floor of the Straits of Florida. The synchroneity with the "Abaco episode" in the western North Atlantic suggests a common trigger. The relatively long duration of the event makes tectonism a likely candidate, even though environmental factors such as fluctuating sea level cannot be ruled out.

The effects of diagenesis are demonstrated in various ways. The number and thickness of hard layers in Units I and III increase with depth. Interstitial-water analyses suggest some dissolution of calcium carbonate with depth, and x-ray-diffraction 


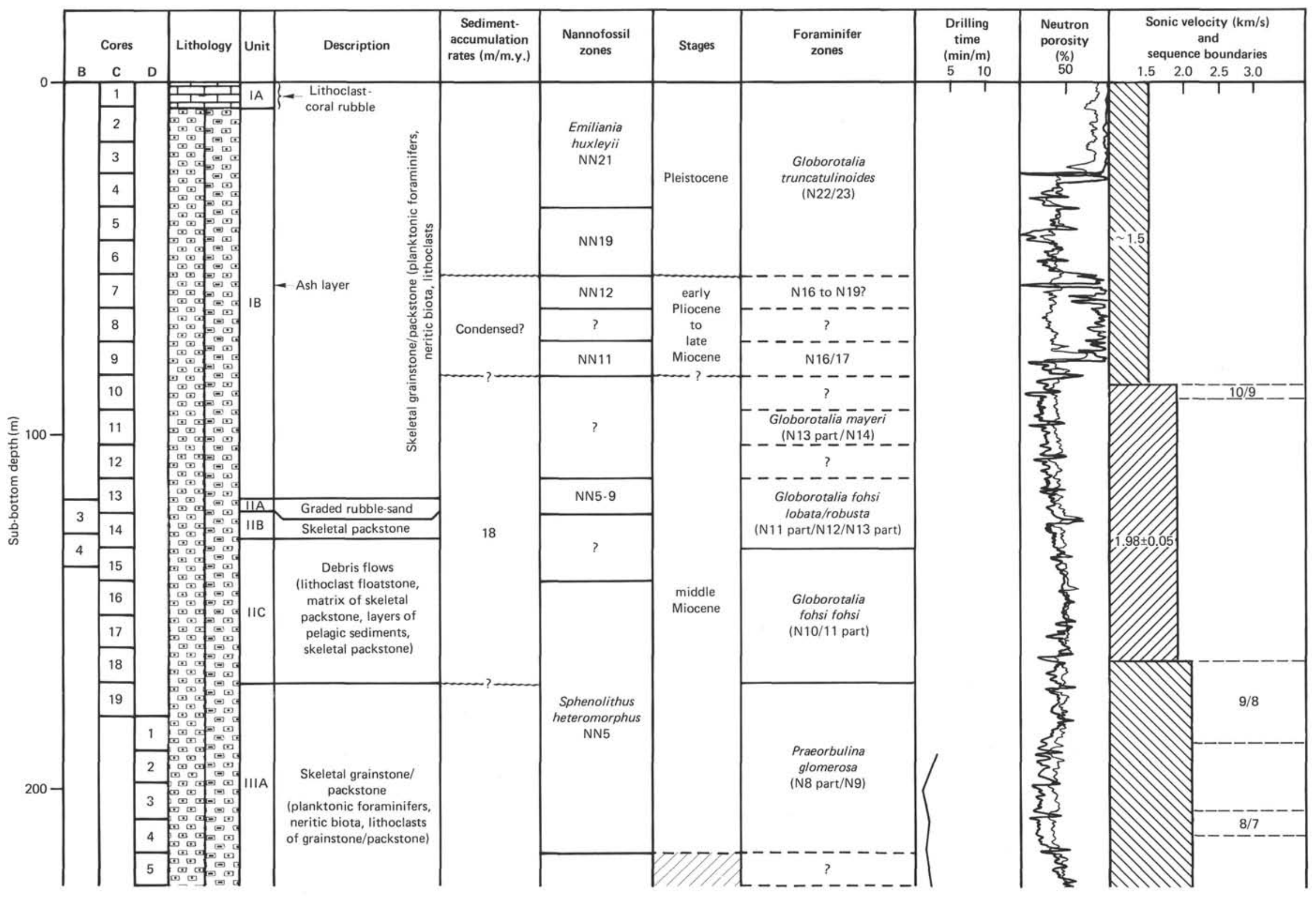




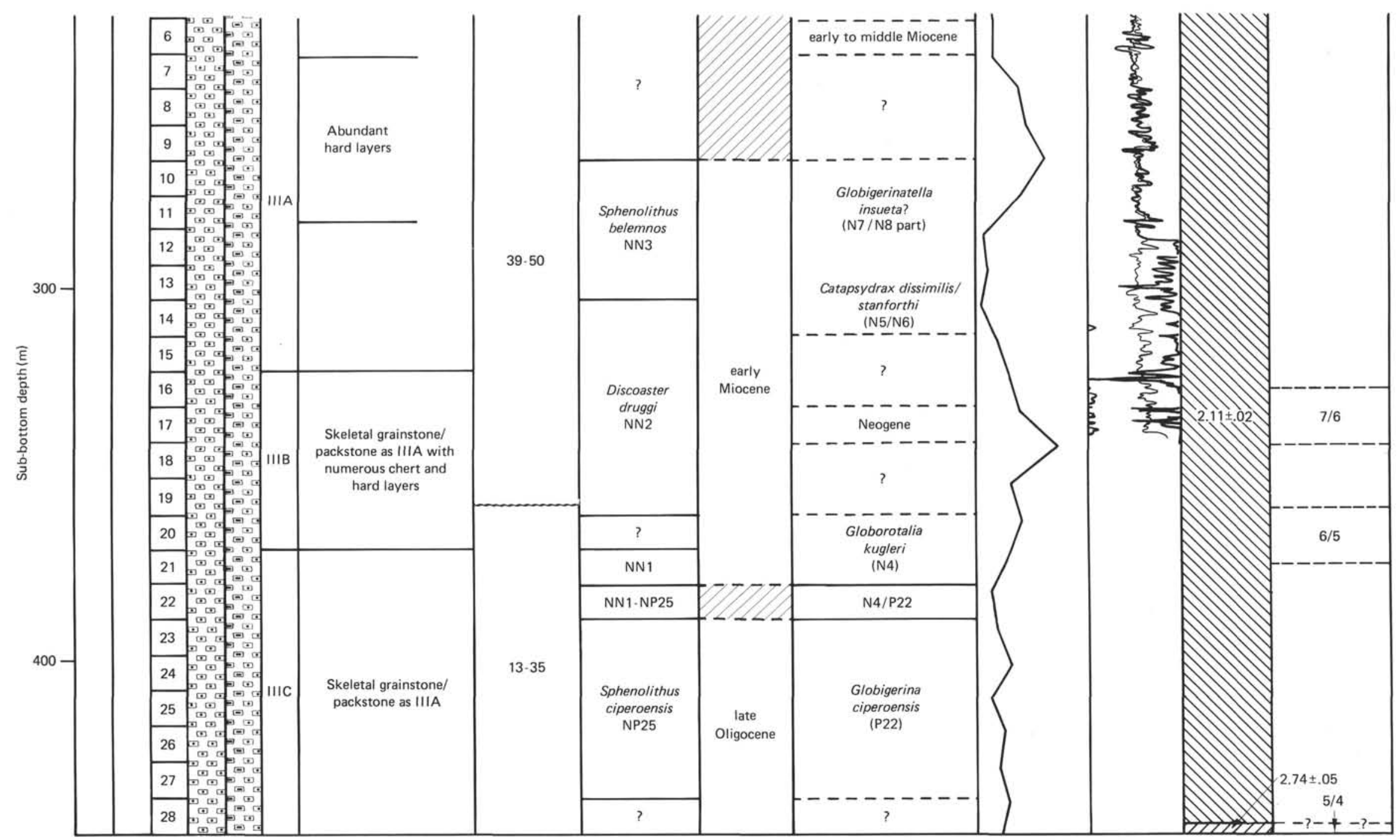

Figure 22. Summary of data from Site 626. 
analysis indicates downhole disappearance of aragonite and magnesian calcite, along with precipitation of calcite cement and some dolomite. However, most of these processes are unexpectedly slow. Magnesian calcite is still present in lower Miocene sediments at $275 \mathrm{~m}$, and aragonite occurs even deeper in the hole. The muddy sediments of Unit II are essentially unlithified, whereas the coeval Abaco Member in the western North Atlantic consists of chalk and limestone. Downhole measurements of physical properties indicate only an insignificant decrease in porosity and sonic velocity of the loose material. The neutron log confirms this observation with regard to porosity. The causes for the retardation of diagenesis remain obscure.

Organic matter in the sequence was scarce and immature, with the exception of flecks and strings of asphalt in middle Miocene skeletal grainstone (Core 626C-19H, CC). This "dead oil" must have originated deeper in the section. It may represent the reworked material of a seepage or the degraded residue of a former accumulation.

Borehole stratigraphy, in conjunction with physical-property measurements and wireline logs, provides some good ties with the seismic stratigraphy developed during the site survey. The alternation of soft and hard layers in the contourite units is consistent with the high-amplitude reflectors observed in these intervals. The interpretation of some seismic patterns as sediment waves, although these were not sampled, has been strengthened by the recovery of extensive contour-current deposits. Finally, the hypothesis that a global lowstand of relative sea level would have caused erosion within the consequently narrower, shallower Straits of Florida received some corroboration.

Even though Site 626 did not reach the mid-Cretaceous target, a comparison of Site 626 and the Great Isaac well (I. Bourgeois, G. Mackenzie, W. Schlager, unpubl. data) provides arguments in favor of the "megabank" hypothesis, which holds that Florida and the Bahama Banks formed a single, unsegmented platform until mid-Cretaceous time. Mid-Miocene and older rocks at Sites 626 and Great Isaac seem to be connected by layer-cake stratigraphy without offset. Oligocene and Miocene sediment facies in the two wells are also similar (Fig. 23). The 850$\mathrm{m}$ relief currently existing between the two wells apparently developed during the late Miocene-Pliocene, when the margin of Greater Bahama Bank prograded westward to its current position. This strongly suggests that the unsampled "target" reflector at Site 626 corresponds to the boundary of Albian platform carbonates and Cenomanian pelagic chalks at Great Isaac. These mid-Cretaceous platform carbonates appear to represent the drowned top of the Florida-northwestern Bahamas megabank.

However, the mid-Cretaceous drowning of the megabank was not complete, which is borne out by continuous shallow-water sequences in the Andros 1 and Cay-Sal IV-1 wells (Paulus, 1972)

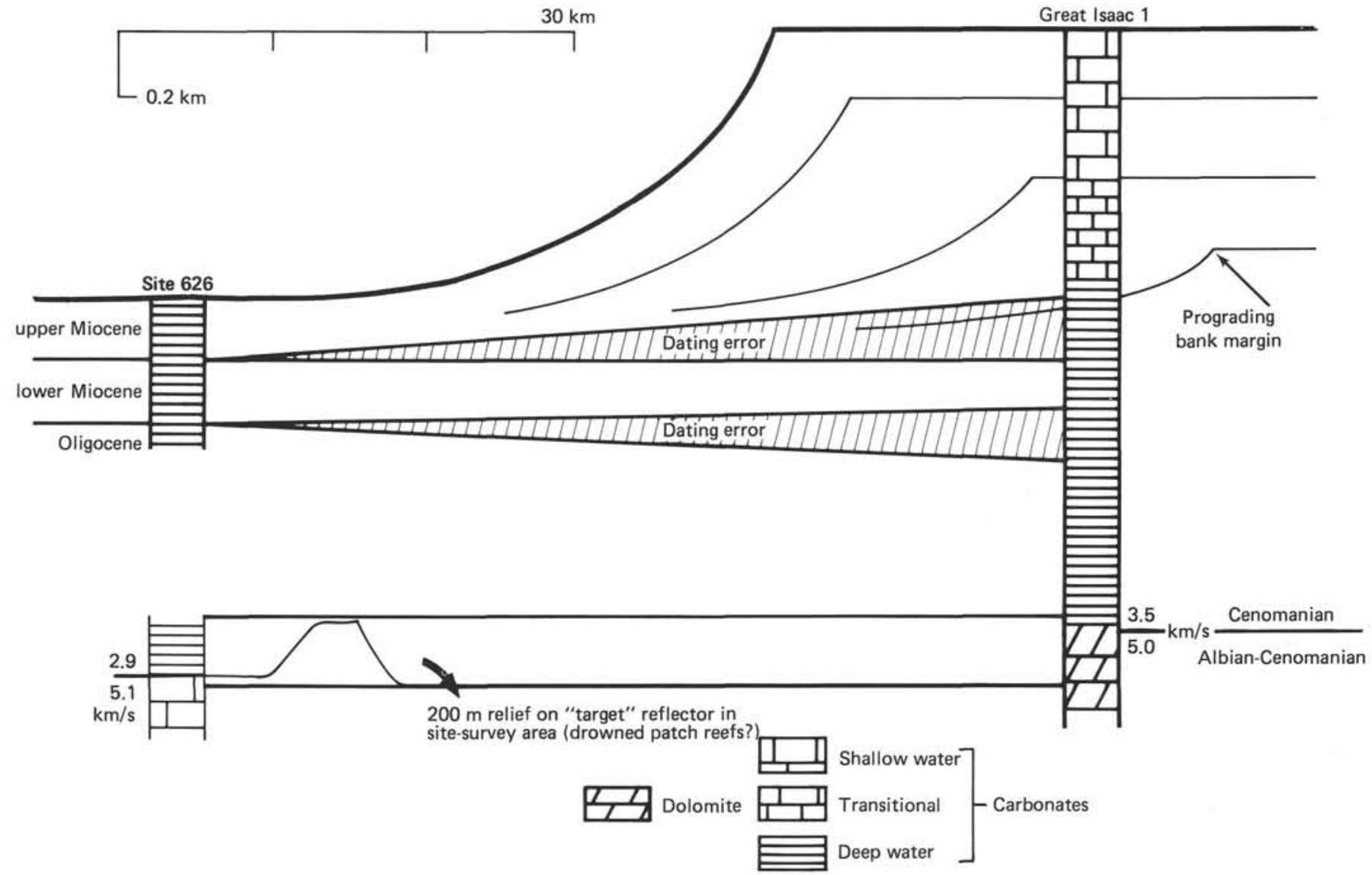

Figure 23. Correlation of stratigraphy at Site 626 with seismic stratigraphy in the Straits of Florida and with the Great Isaac 1 well on Great Bahama Bank. Heavy lines represent factual information; thin lines are interpretations. The Great Isaac well complements results of seismic surveys and drilling at Site 626. Horizontal time lines between Great Isaac and ODP Site 626 argue against fault control of the present bank margin. A similar elevation of drowned bank top in the Great Isaac well and a prominent seismic reflector in the Straits support the interpretation of this reflector as the top of a Cretaceous platform (the "megabank"). The succession of facies encountered in the Great Isaac well indicates mid-Cretaceous drowning, followed by Tertiary progradation of the bank margin. 
as well as sections on the Bahama Escarpment (Freeman-Lynde et al., 1981). By the late Oligocene, these surviving platforms had risen more than $500 \mathrm{~m}$ above the seafloor in the Straits of Florida. This is indicated by a comparison of the elevation of late Oligocene-early Miocene deposits in the Straits and in the Andros and Cay-Sal wells. Furthermore, seismic reflector 5/4 (Oligocene) can be traced from the bottom of Hole 626D to the top of the Oligocene platform on the Miami Terrace, $800 \mathrm{~m}$ higher (Freeman-Lynde et al., 1981).

\section{REFERENCES}

Benson, W. E., Sheridan, R. E., et al., 1978. Init. Repts. DSDP, 44: Washington (U.S. Govt. Printing Office).

Bliefnick, D. M., Robertson, A. H. F., and Sheridan, R. E., 1983. Deposition and provenance of Miocene intraclastic chalks, Blake-Bahama Basin, western North Atlantic. In Sheridan, R. E., Gradstein, F. M., et al., Init. Repts. DSDP, 76: Washington (U.S. Govt. Printing Office), 727-748.

Brooks, I. H., 1979. Fluctuations in the transport of the Florida Current at periods between tidal and two weeks. J. Phys. Oceanogr., 9: 1048-1053.

Buffler, R. T., 1984. Early history and structure of the deep Gulf of Mexico basin [paper presented at the Gulf Coast SEPM Research Symposium, Austin, TX].

Buffler, R. T., et al., 1981. A model for the early evolution of the Gulf of Mexico basin. In Geology of Continental Margins Symposium: Proc. 26th Int. Congr., Oceanol. Acta, C3:120-136.

Butterlin, J., and Moullade, M., 1983. Redeposited and/or reworked larger benthic Foraminifera from Miocene debris flows, Blake-Bahama Basin (western North Atlantic), Deep Sea Drilling Project Legs 44 (Site 391) and 76 (Site 345). In Sheridan, R. E., and Gradstein, F. M., et al., Init. Repts. DSDP, 76: Washington (U.S. Govt. Printing Office), 645-650.

Collinson, D. W., 1983. Methods in Rock Magnetism and Palaeomagnetism: London (Chapman and Hall).

Davis, R. R., Hall, J. E., Boutemy, Y. L., and Flaum, C., 1981. A dual porosity CNL* logging system. Soc. Pet. Eng. Reprint 10296.

Ellwood, B. B., 1980. Induced and remanent magnetic properties of marine sediments as indicators of depositional processes. Mar. Geol., 38:233-244.

Freeman-Lynde, R., Cita, M. B., Jadoul, F., Miller, E. L., and Ryan, W. B. F., 1981. Marine geology of the Bahama Escarpment: Mar. Geol., 44:119-156.

Gieskes, J. M., 1974. Interstitial water studies, Leg 25. In Simpson, E. S. W., Schlich, R., et al., Init. Repts. DSDP, 25: Washington (U.S. Govt. Printing Office), 361-394.

1981. Deep-sea drilling interstitial water studies: Implications for chemical alteration of the oceanic crust, Layers 1 and 2. SEPM Spec. Publ., 32:149-167.
Hollister, C. D., Ewing, J. I., et al., 1972. Init. Repts. DSDP, 11: Washington (U.S. Govt. Printing Office).

Meyerhoff, A. A., and Hatten, C. W., 1974. Bahamas salient of North America. In Burk, C. A., and Drake, C. L. (Eds.), The Geology of Continental Margins: New York (Springer-Verlag), 429-446.

Mullins, H. T., and Lynts, G. W., 1977. Origin of the northwestern Bahama platform: review and reinterpretation. Geol. Soc. Am. Bull., 88:1447-1461.

Paulus, F. J., 1972. The geology of Site 98 and the Bahama Platform. In Hollister, C. D., Ewing, J. I., et al., Init. Repts. DSDP, 11: Washington (U.S. Govt. Printing Office), 877-897.

Perry, E. A., Jr., Gieskes, J. M., and Lawrence, J. R., 1976. Mg, Ca and $\mathrm{O}^{18} / \mathrm{O}^{16}$ exchange in the sediment-pore water system, Hole 149 , DSDP. Geochim. Cosmochim. Acta, 40:413-423.

Radhakrishnamurty, C., Likhite, S. D., Amin, B. S., and Somayajulu, B. L. K., 1972. Magnetic susceptibility stratigraphy in ocean sediment cores. Earth Planet. Sci. Lett., 4:464-468.

Sayles, F. L., and Manheim, F. T., 1975. Interstitial solutions and diagenesis in deeply buried marine sediments: results from the Deep Sea Drilling Project. Geochim. Cosmochim. Acta, 39:103-127.

Schlager, W., Austin, J. A., Jr., et al., 1984. Early Cretaceous platform re-entrant and escarpment erosion in the Bahamas. Geology, 12: 147-150.

Schlager, W., Buffler, R. T., Angstadt, D., and Phair, R., 1984. Geologic history of the southeastern Gulf of Mexico. In Buffler, R. T., Schlager, W., et al., Init. Repts. DSDP, 77: Washington (U.S. Govt. Printing Office), 715-738.

Schlager, W., and Ginsburg, R. N., 1981. Bahama carbonate platformsthe deep and the past. Mar. Geol., 44:1-24.

Sheridan, R. E., 1974. Atlantic continental margin of North America. In Burk, C. A., and Drake, C. L. (Eds.), Geology of Continental Margins: New York (Springer-Verlag), 391-407.

Sheridan, R. E., Crosby, J. T., Bryan, G. M., and Stoffa, P. L., 1981. Stratigraphy and structure of southern Blake Plateau, northern Florida Straits, and northern Bahama Platform from multichannel seismic reflection data. AAPG Bull., 65:2571-2593.

Sheridan, R. E., Gradstein, F. M., et al., 1983. Init. Repts. DSDP, 76: Washington (U.S. Govt. Printing Office).

Talwani, M., Worzel, J. L., and Ewing, M., 1960. Gravity anomalies and structure of the Bahamas. 2nd Caribbean Geol. Conf. Trans., Univ. Puerto Rico, 156.

Tator, B. A., and Hatfield, L. E., 1975. Bahamas represent complex geology. Oil Gas J., 73(43):172-176; 73(44):120-122.

Vail, P. R. and Hardenbol, J., 1979. Sea level changes during the Tertiary: Oceanus, 22:71-80.

Vail, P. R., Mitchum, R. M., Jr., and Thompson, S., III, 1977. Seismic stratigraphy and global changes of sea level, Part 4: Global cycles of relative changes of sea level. In Payton, C. E. (Ed.), Seismic Stratigraphy-Applications to Hydrocarbon Exploration: AAPG Mem., 26: 83-97. 


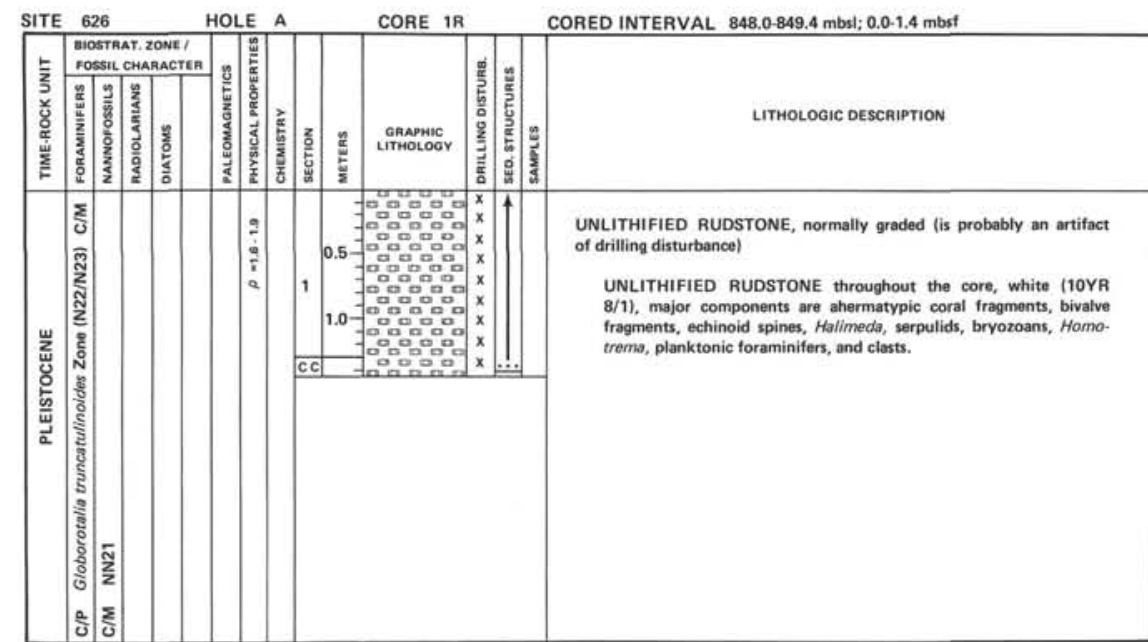

Information on Core Description Forms, for ALL sites, represents field notes taken aboard ship. Some of this information has been refined in accord with post-cruise findings, but production schedules prohibit definitive correlation of these forms with subsequent findings. Thus the reader should be alerted to the occasional ambiguity or discrepancy.

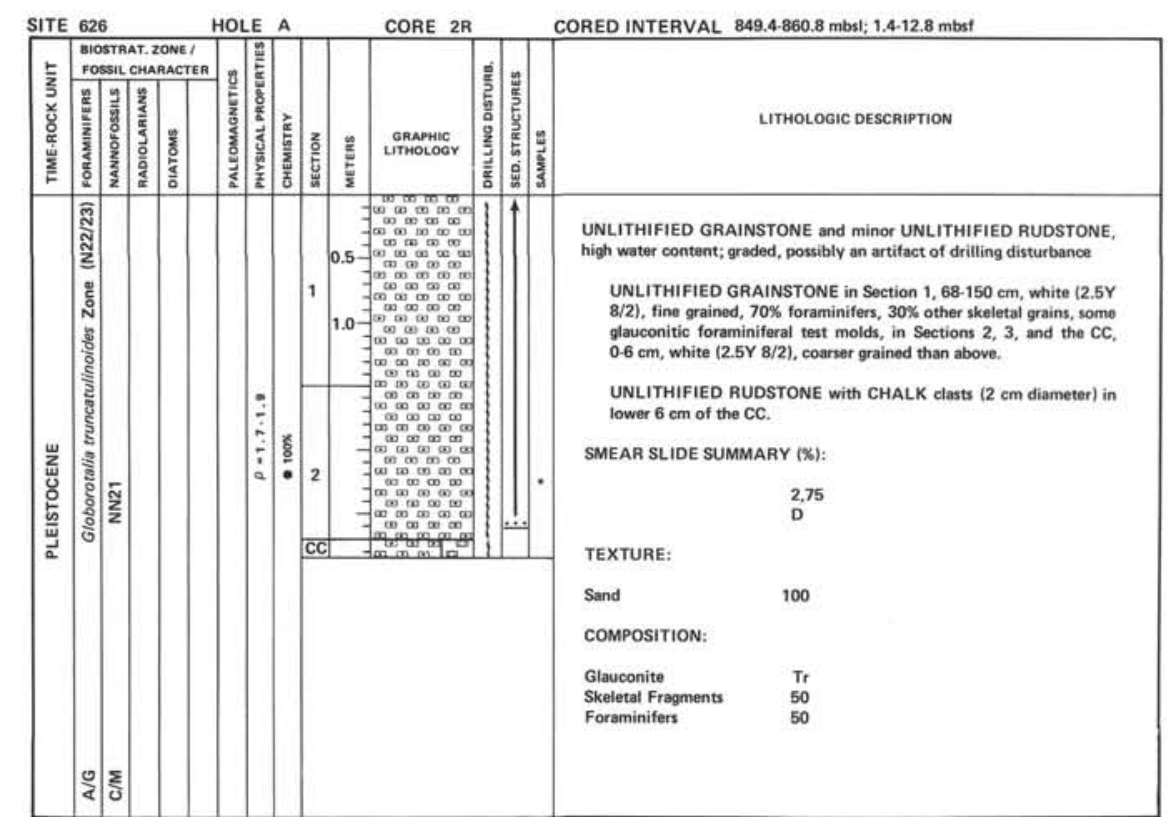




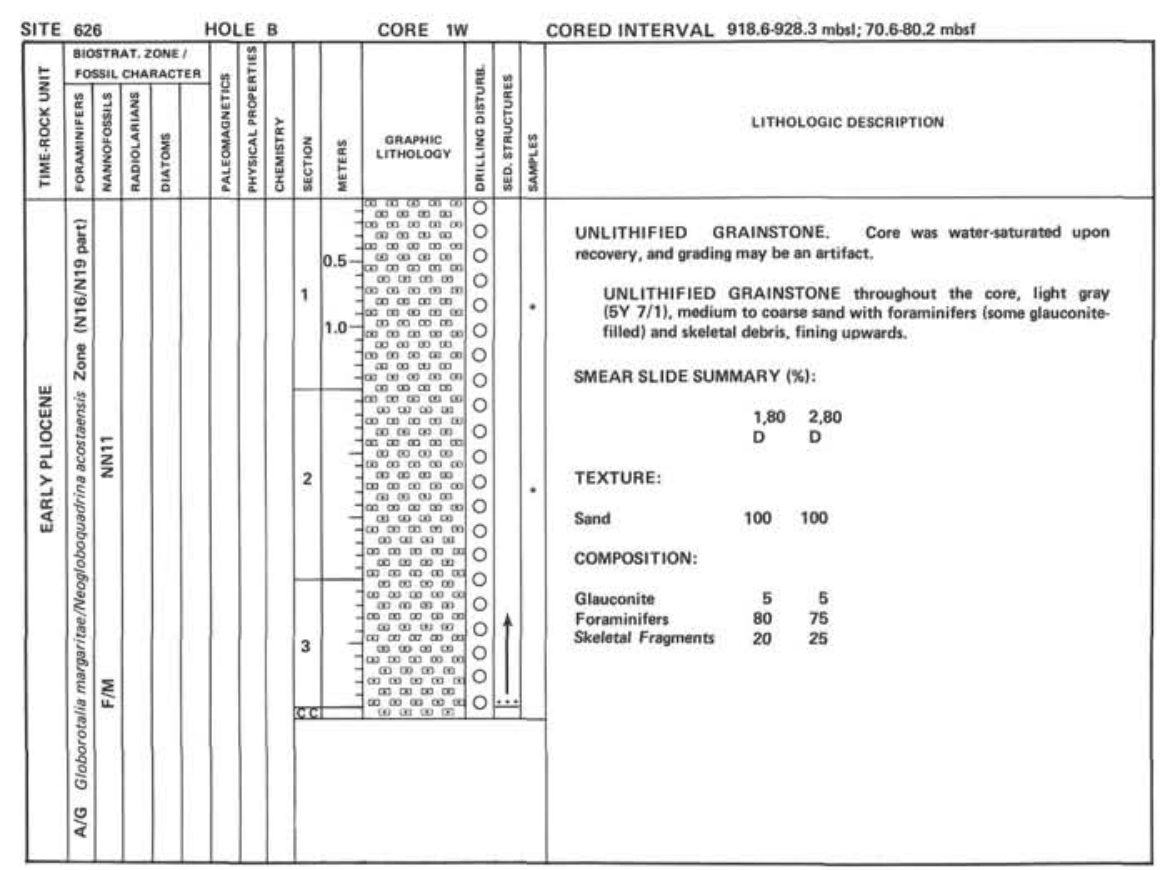

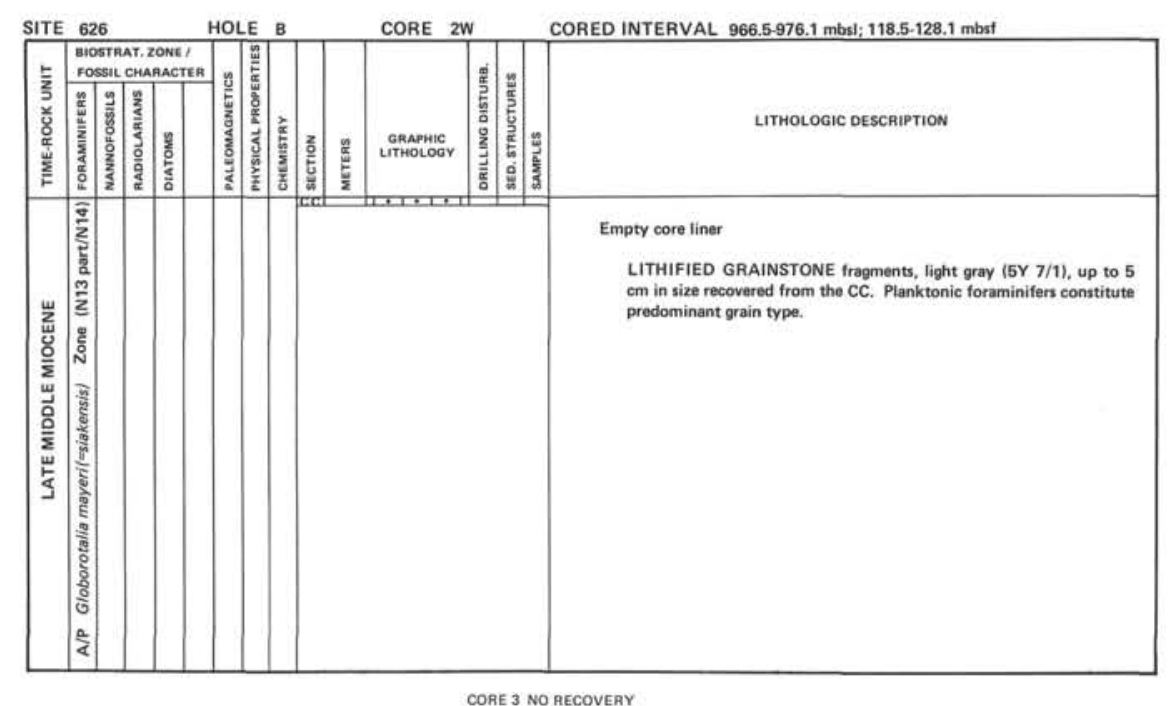

CORE 3 NO PECOVERY 


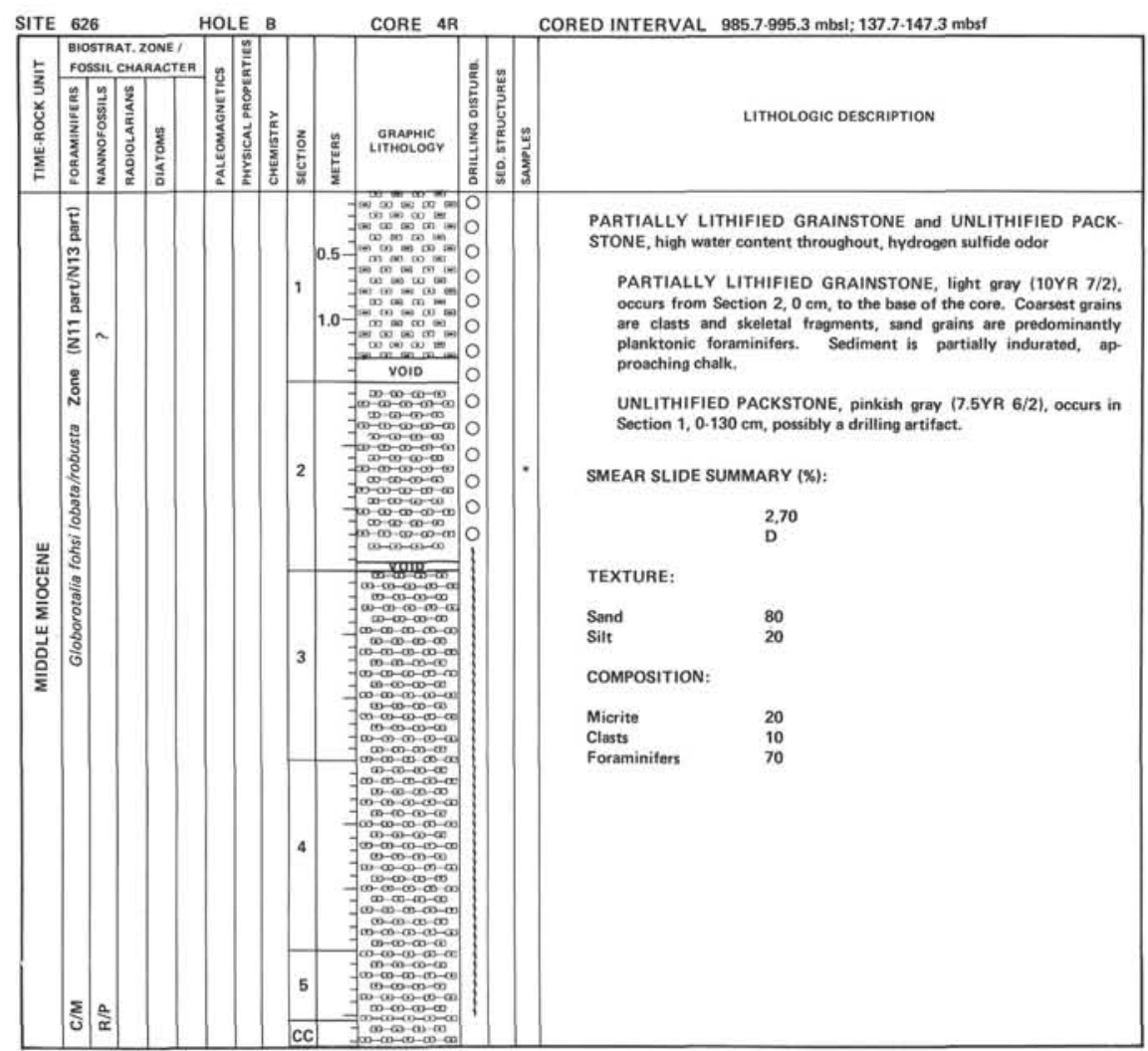

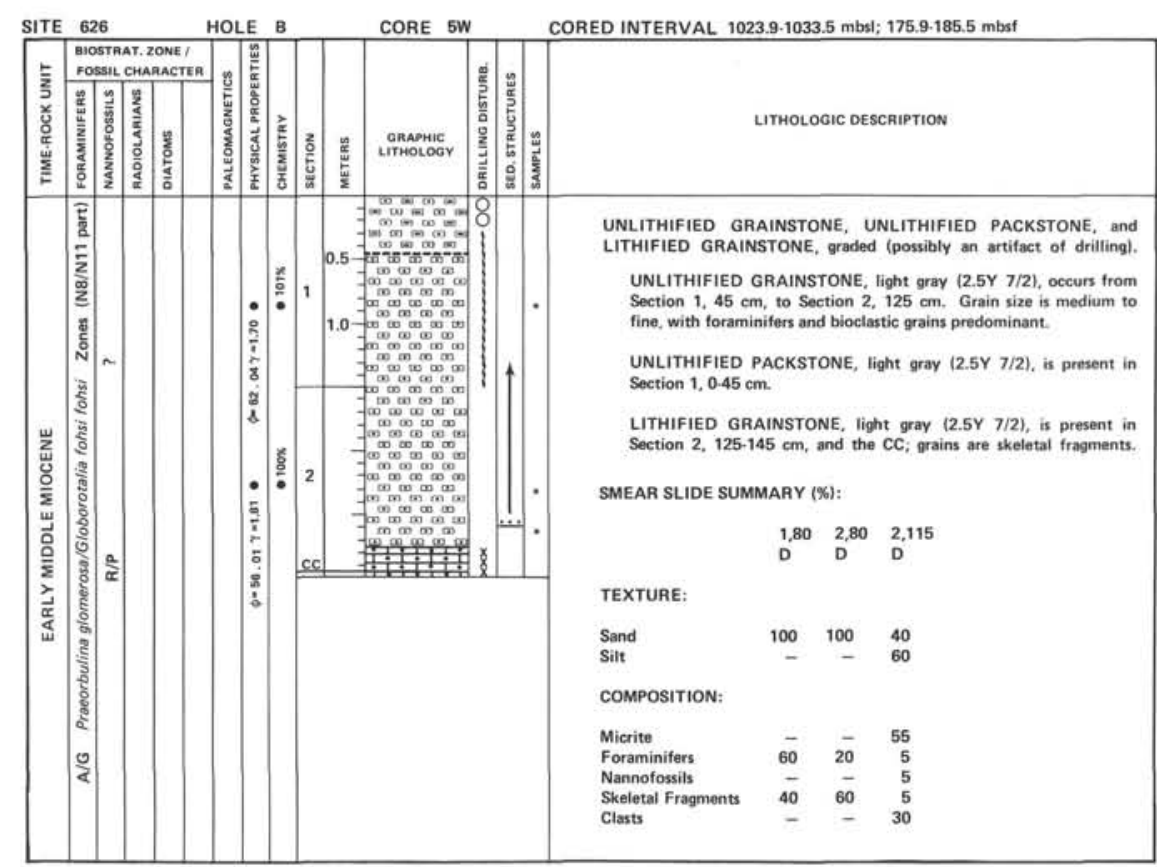



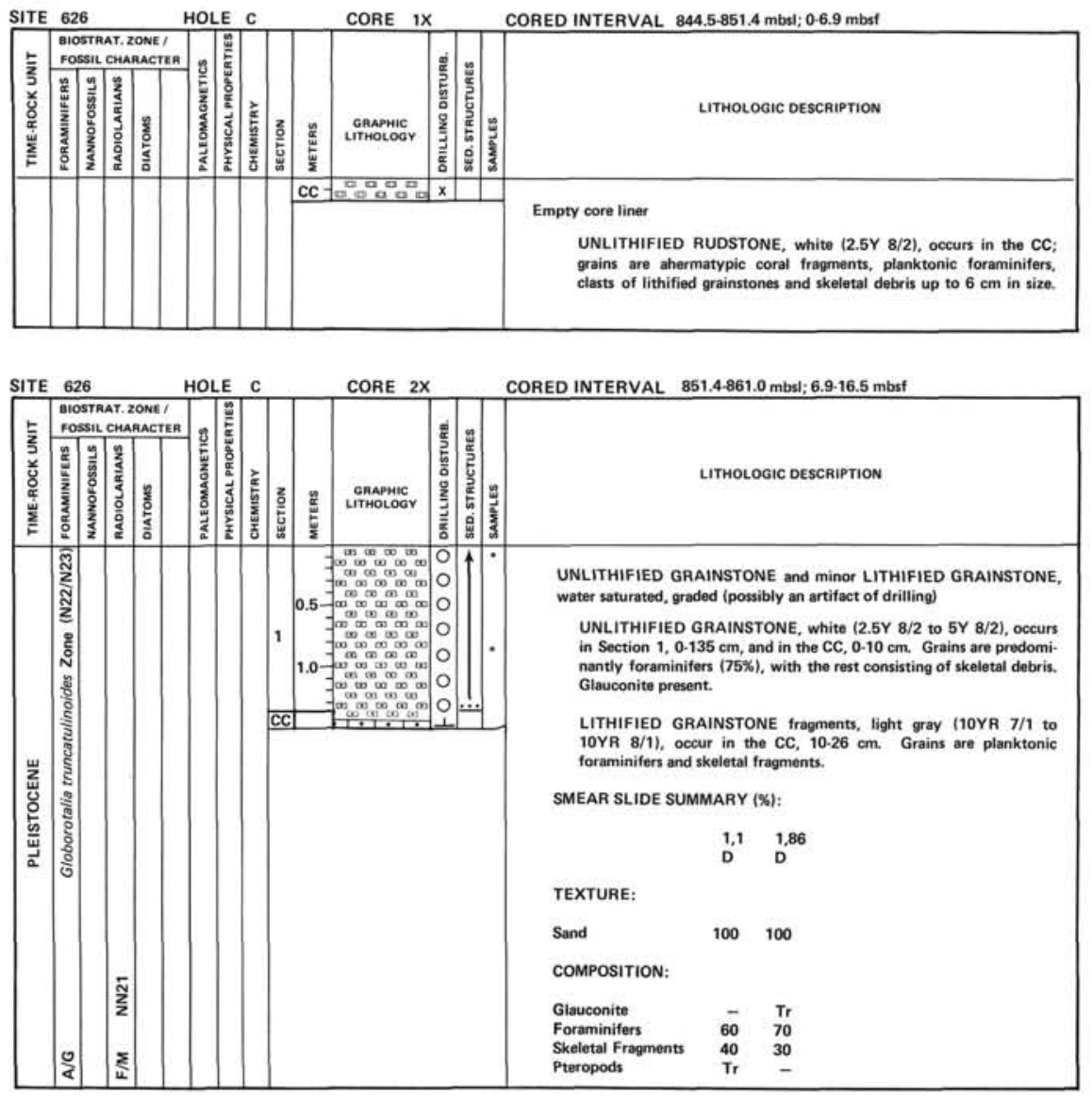
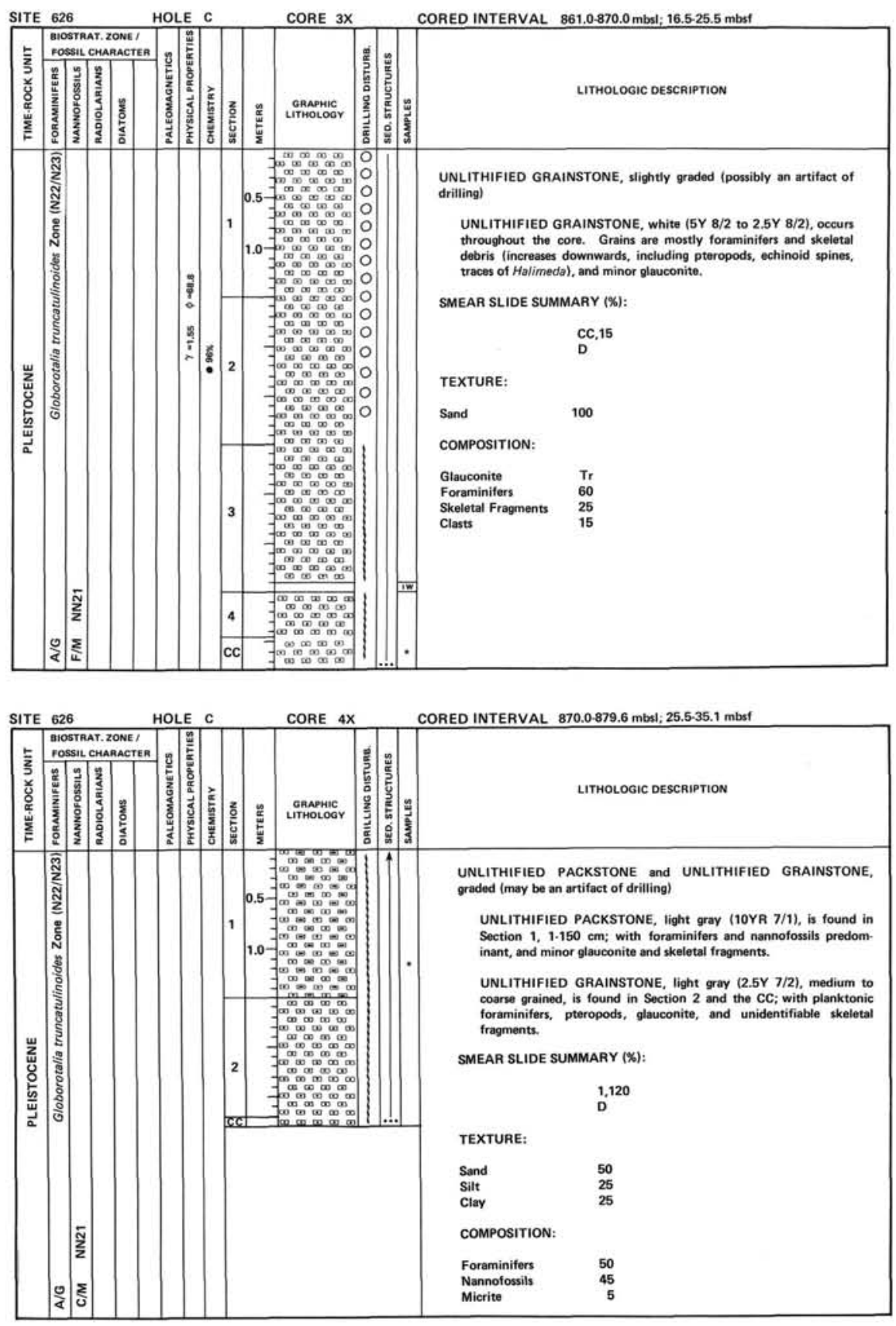


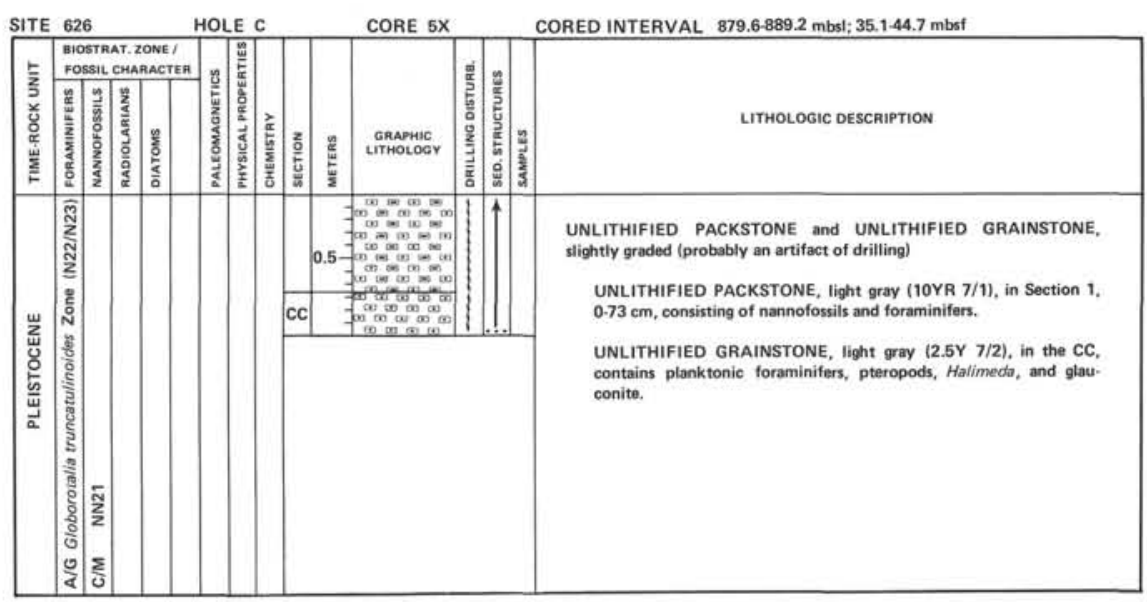

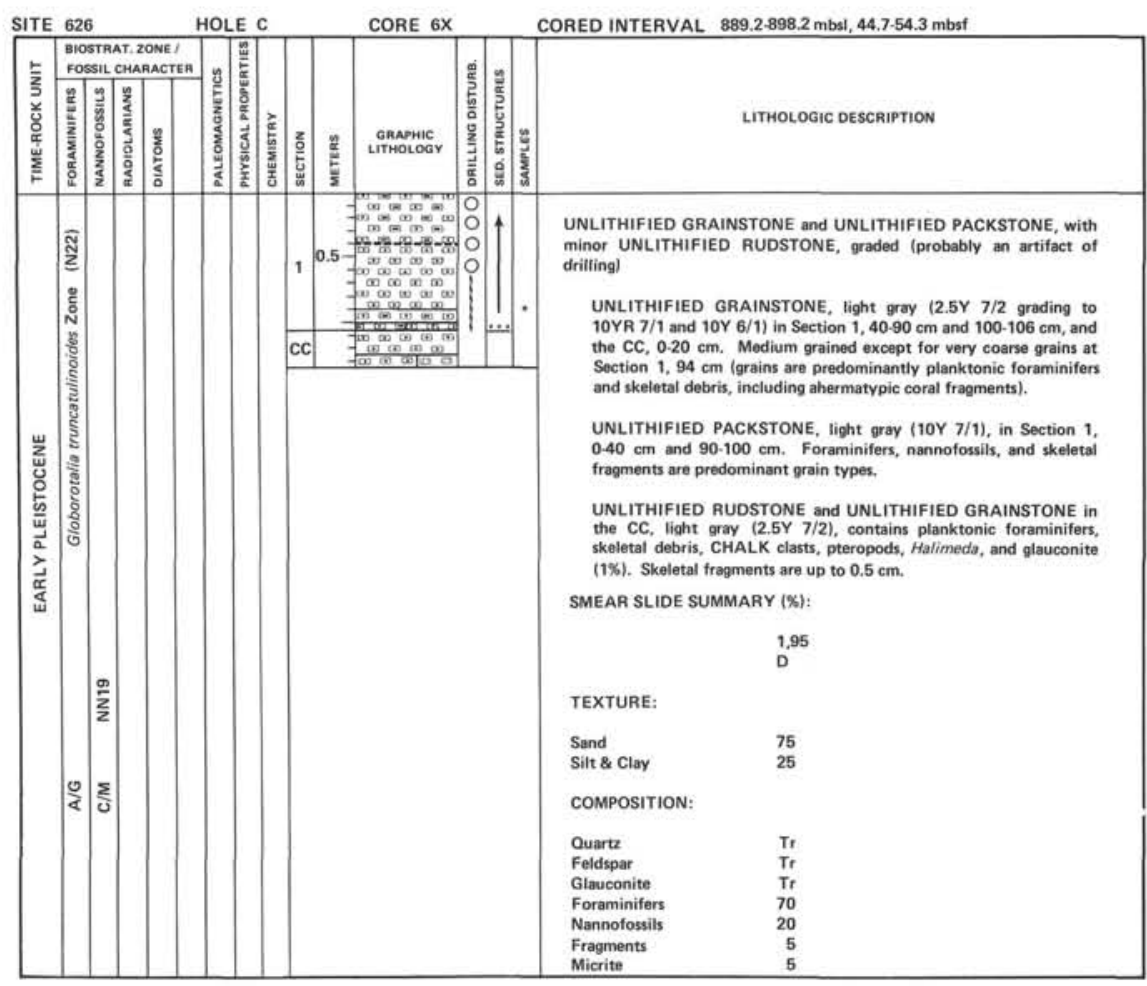

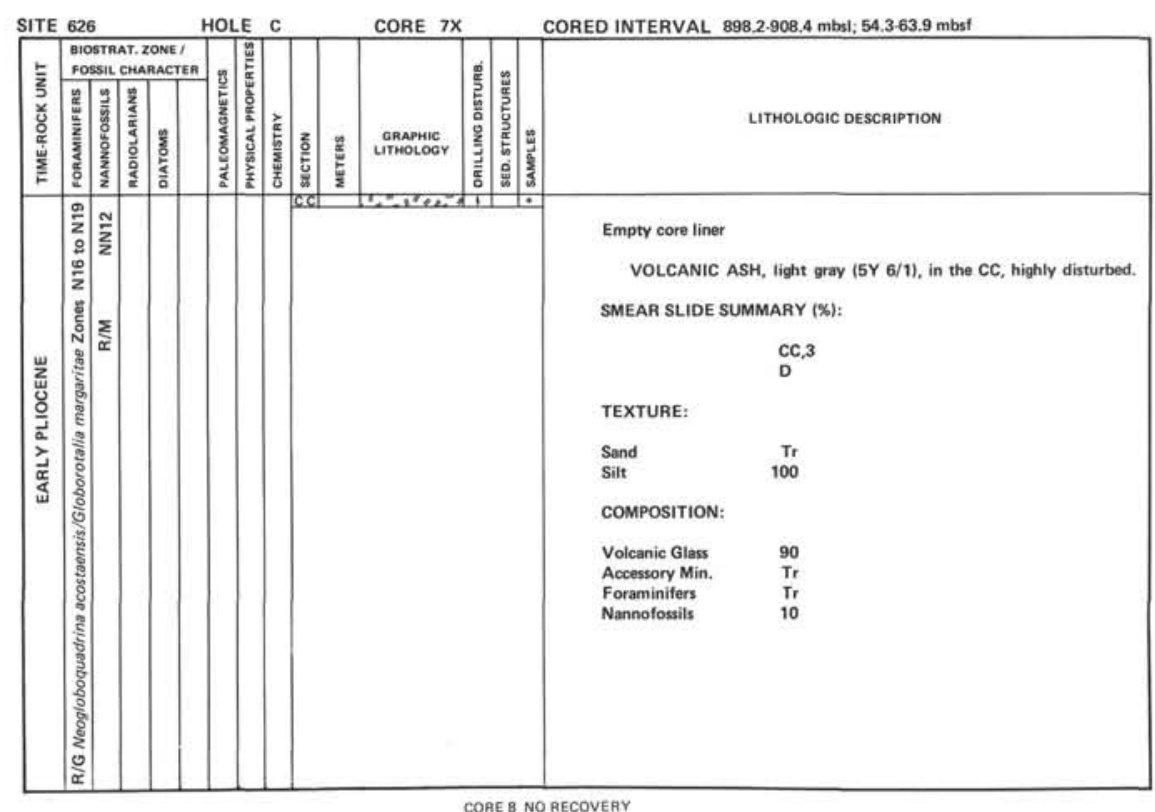

CORE B NO RECOVEAY

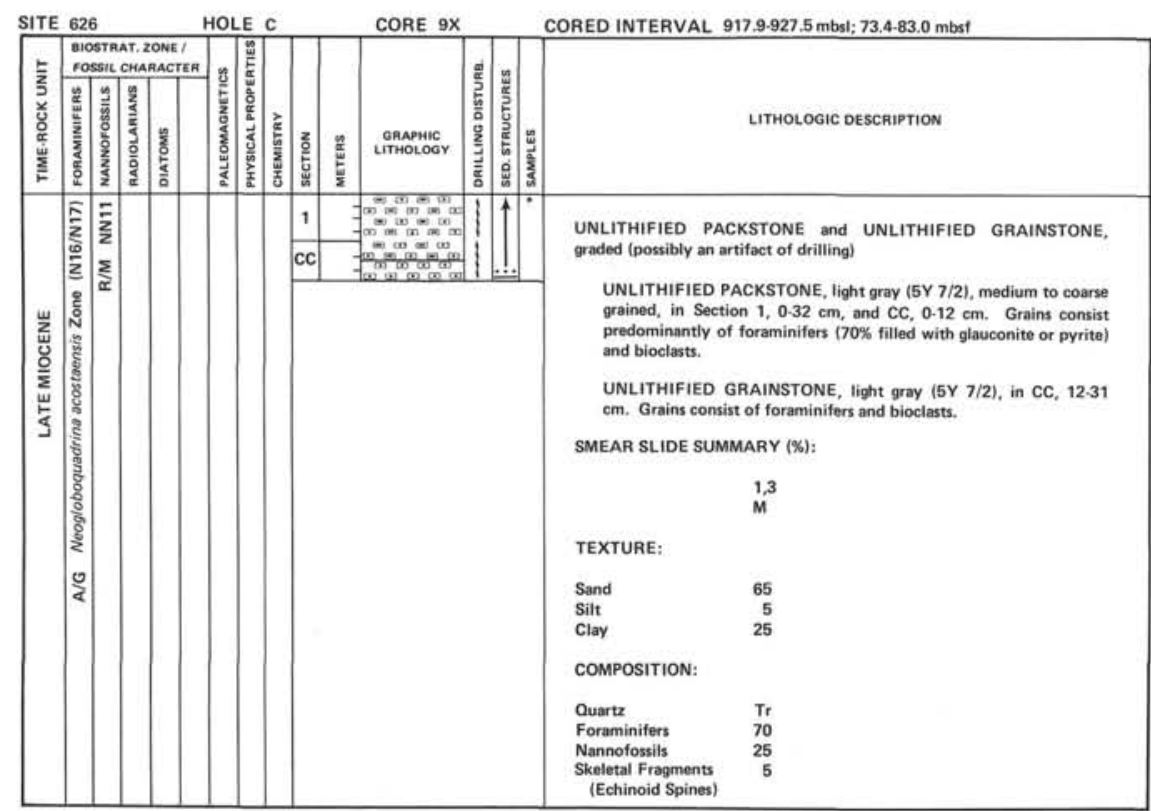

CORE 10 NO RECOVERY 


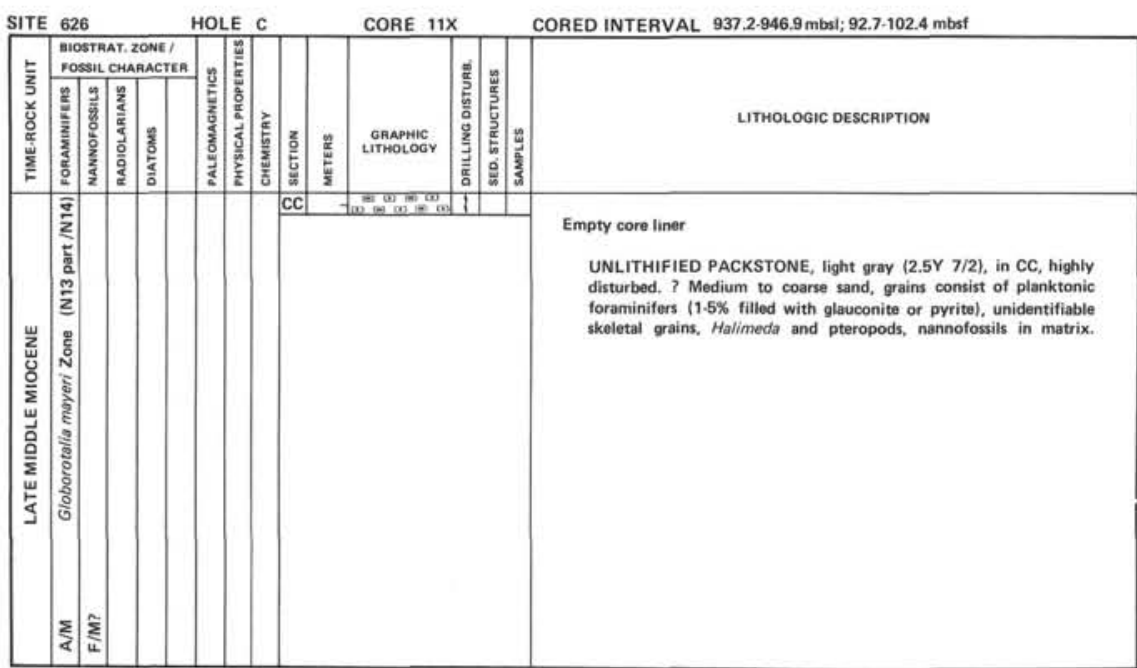

CORE 12 NO RECOVERY

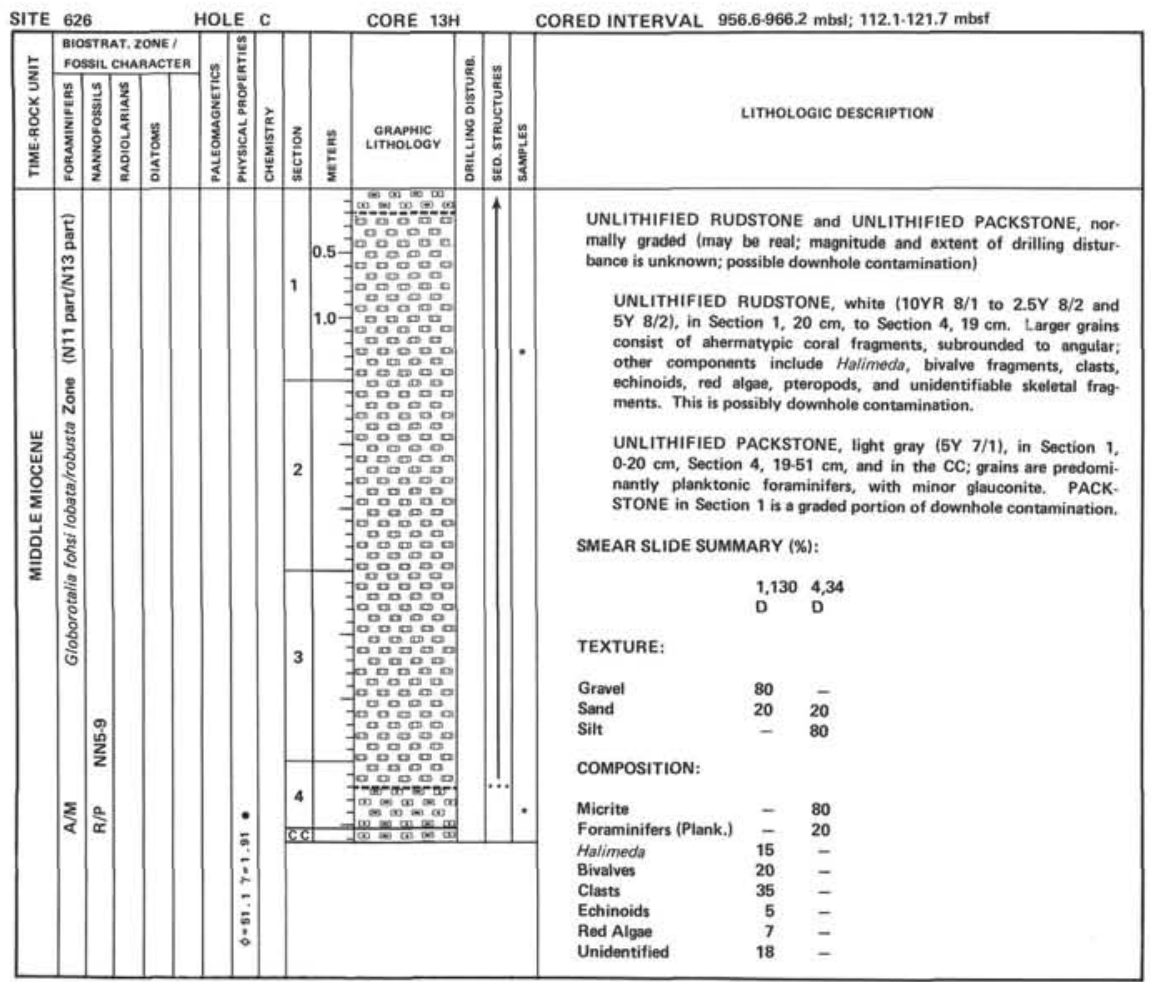

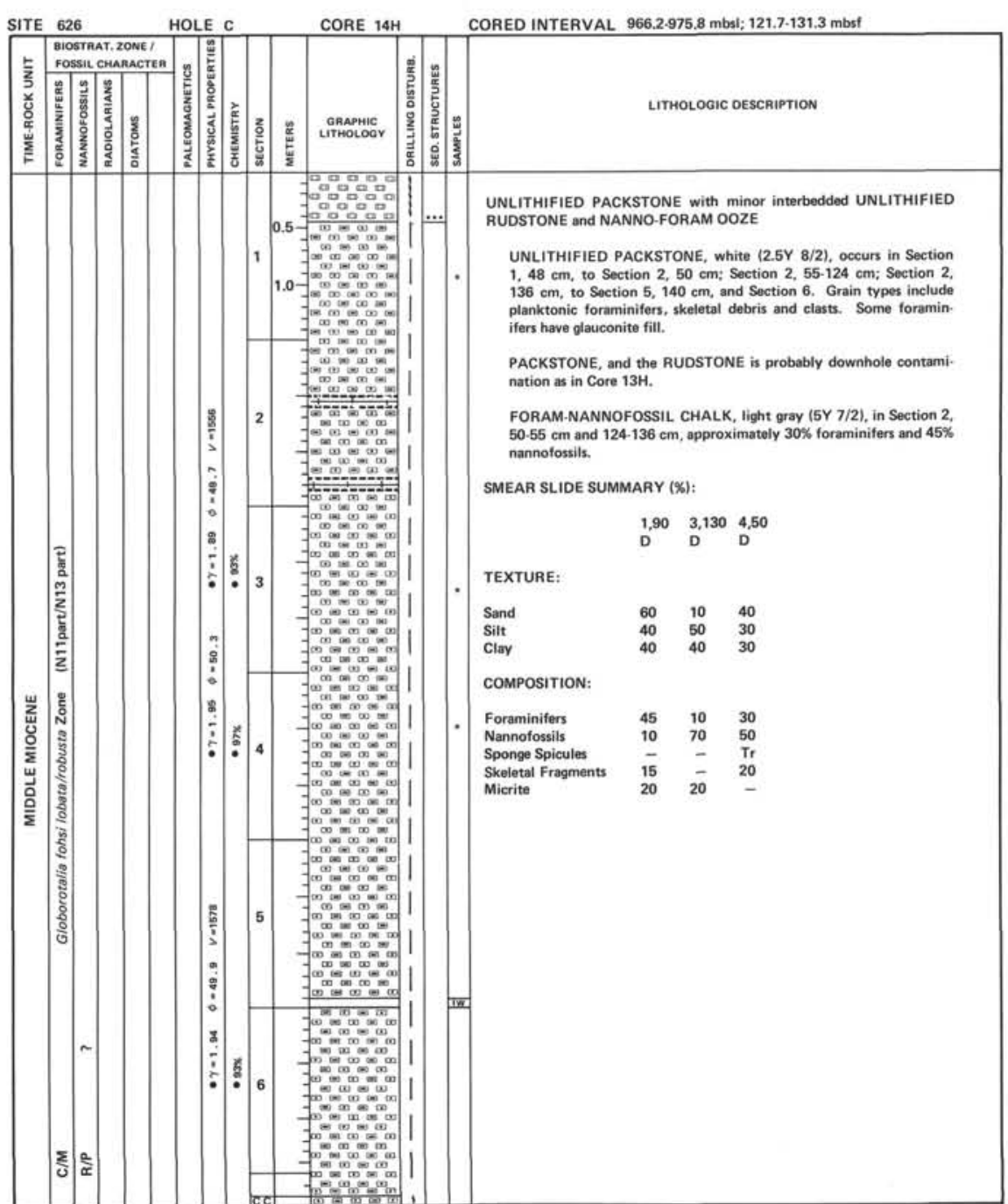



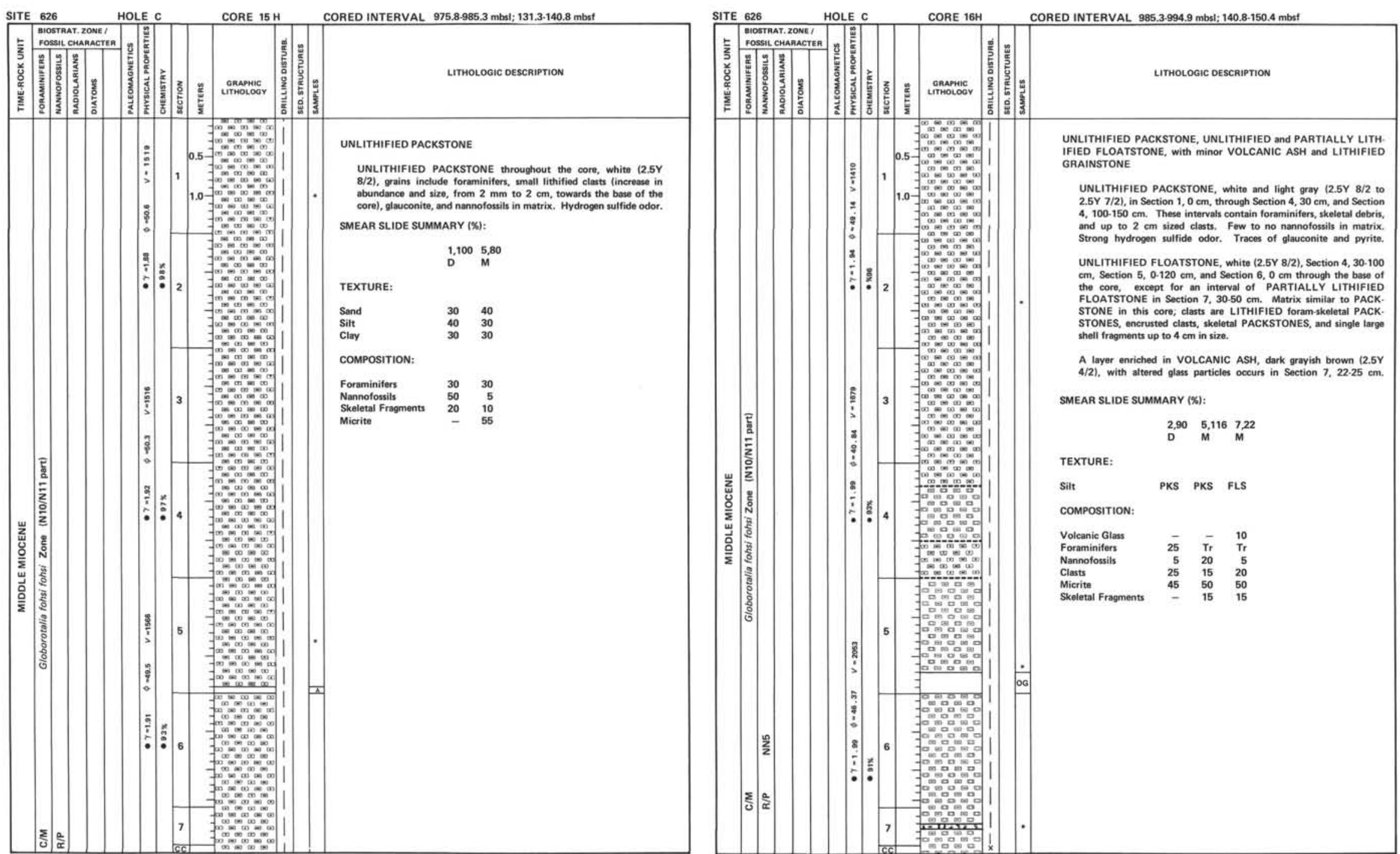


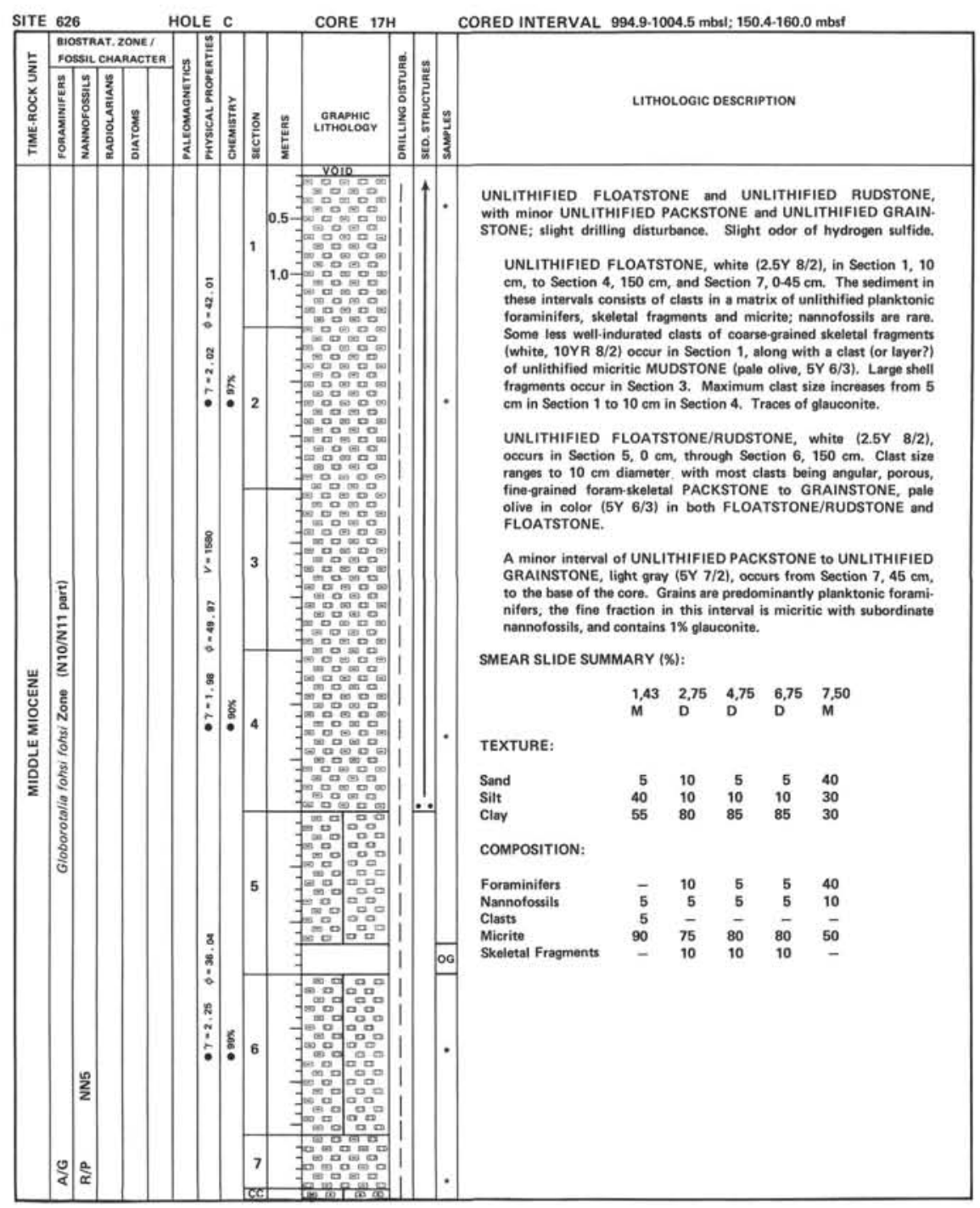

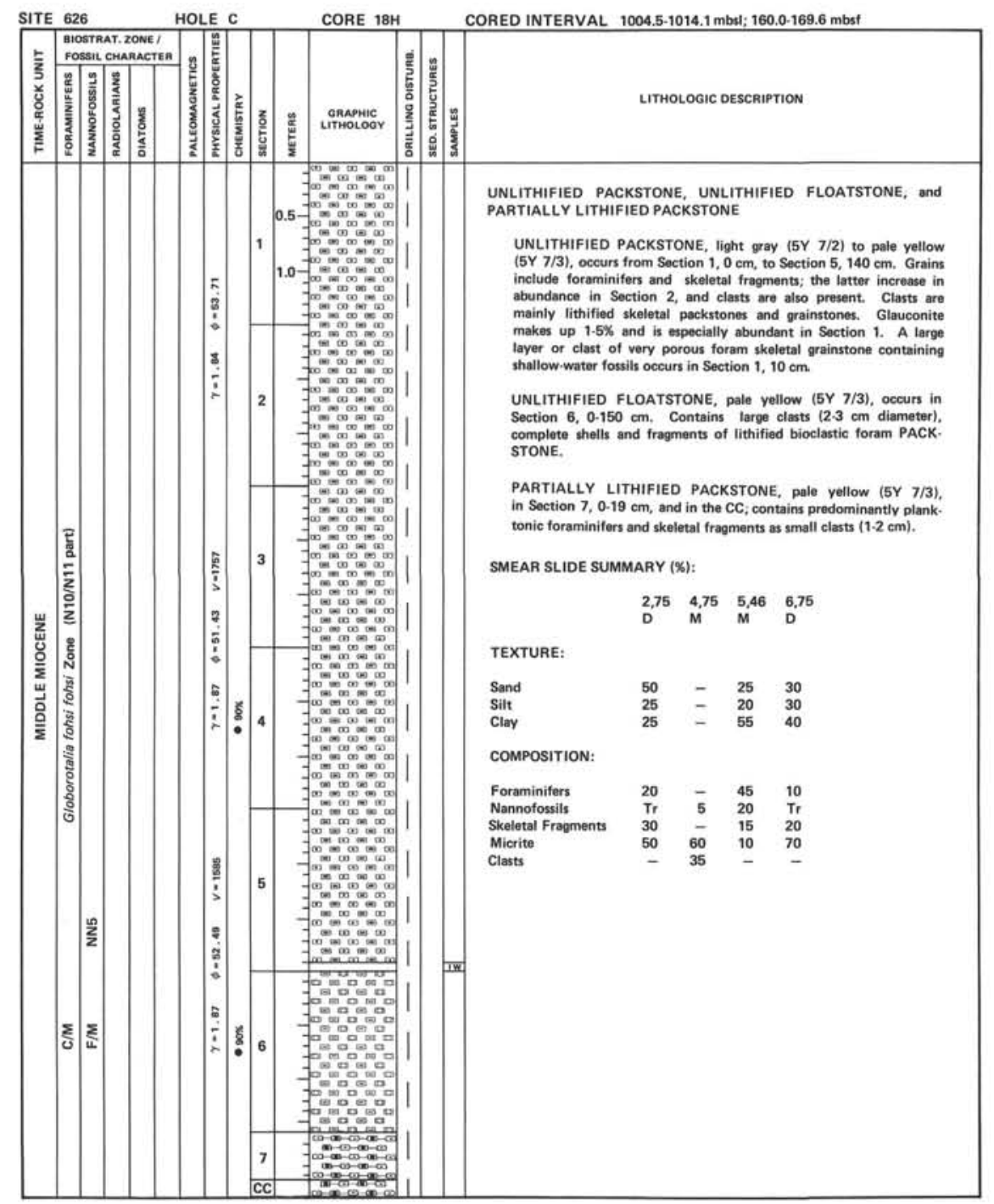




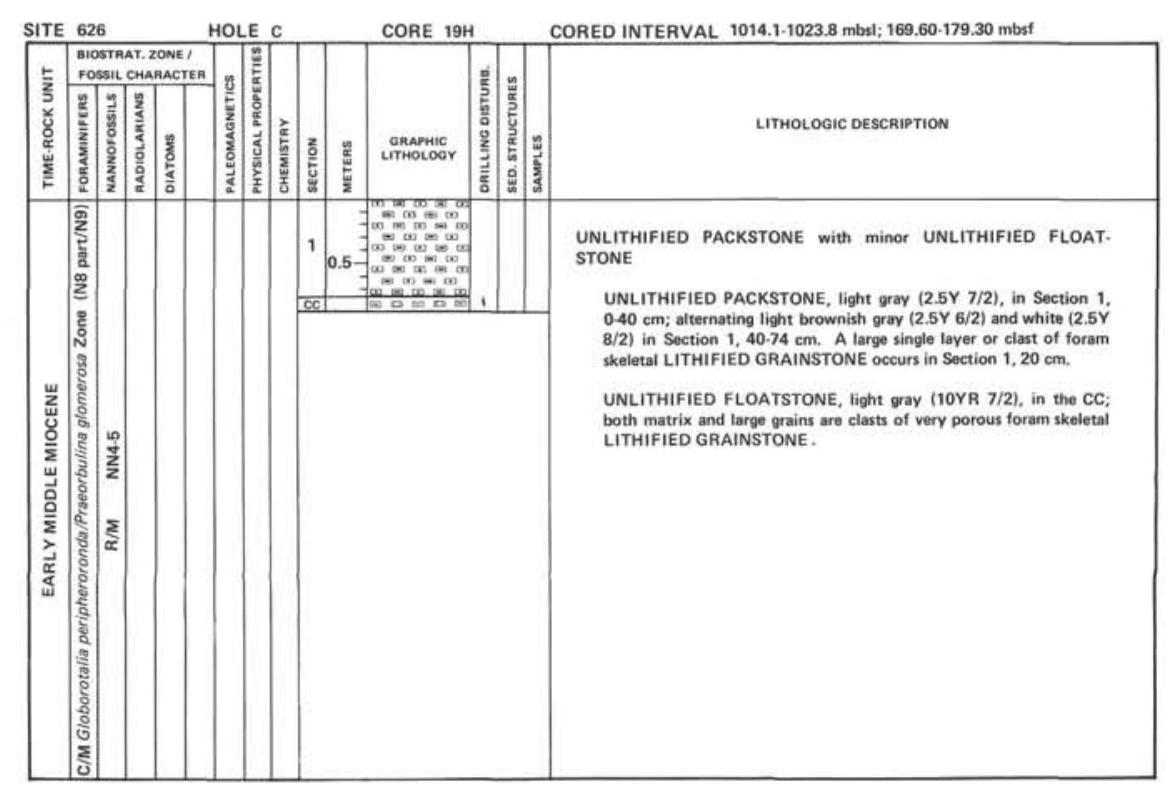




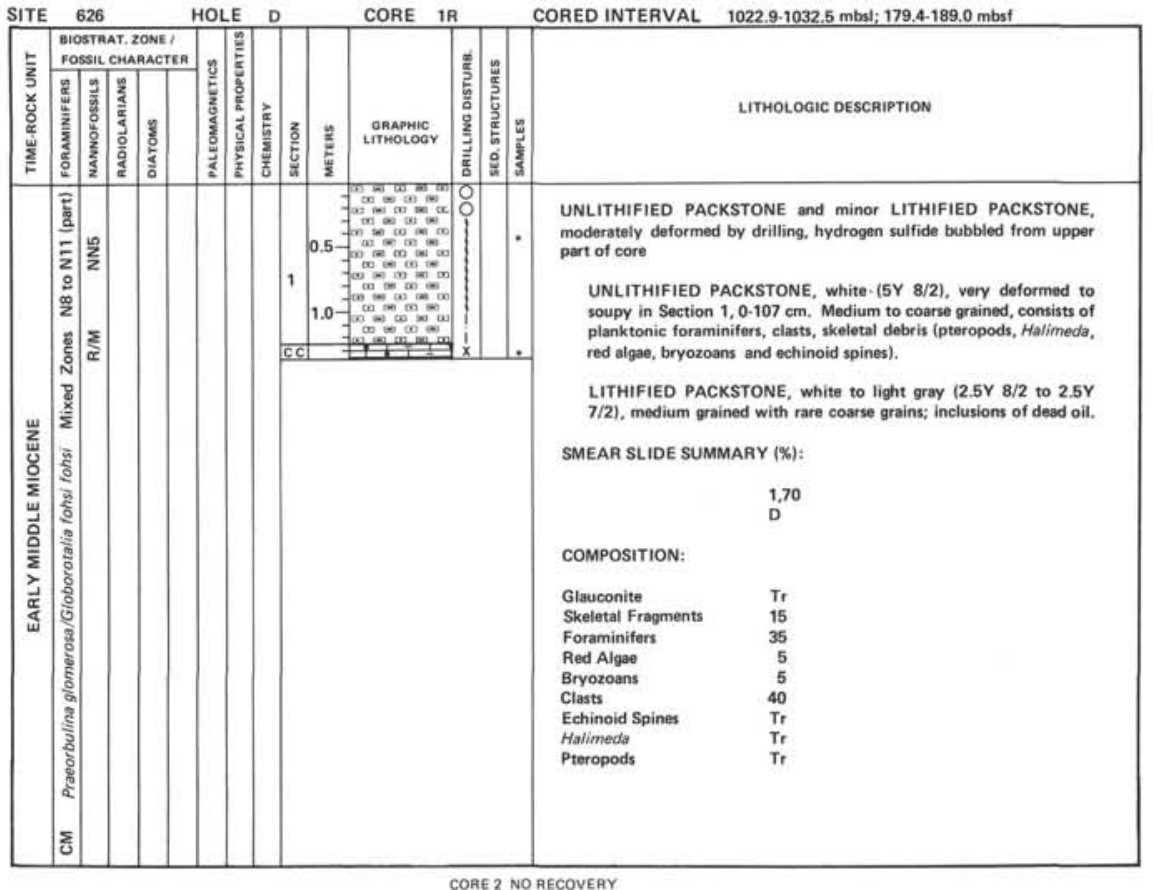

CORE 2 NO RECOVERY

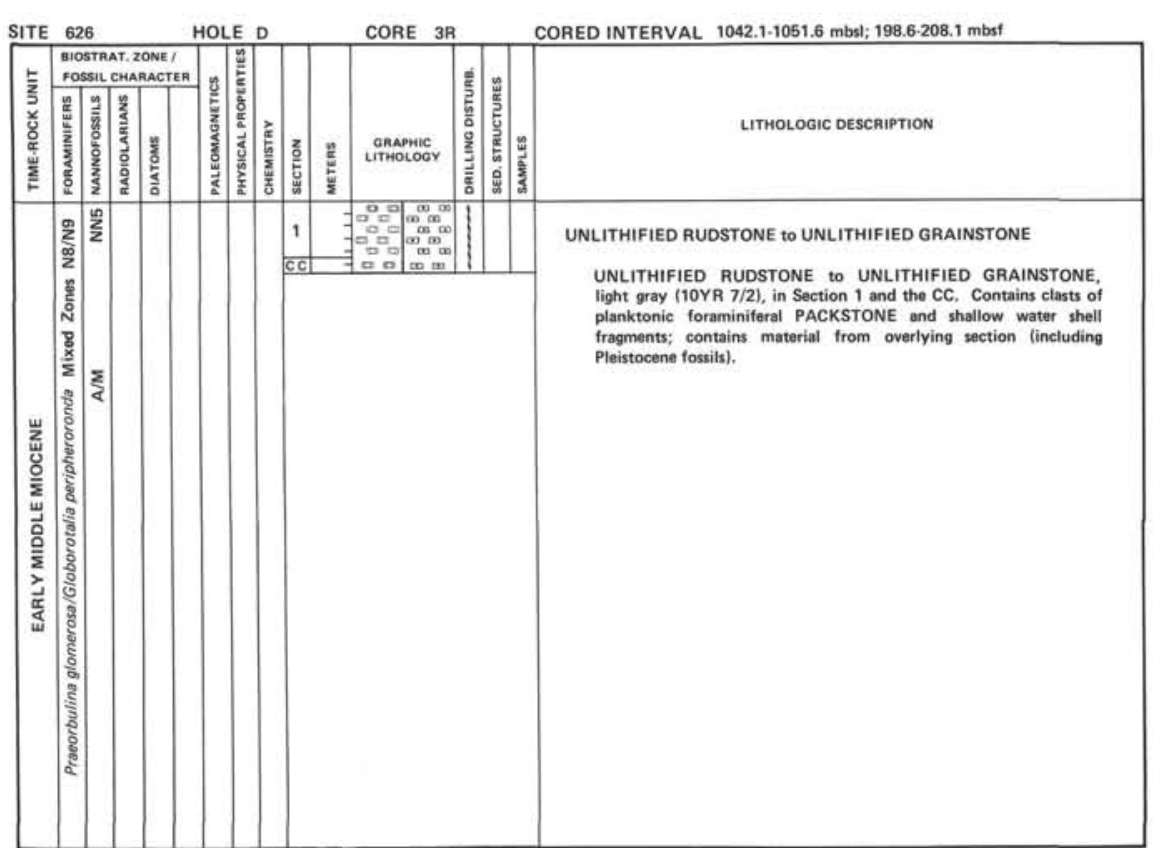

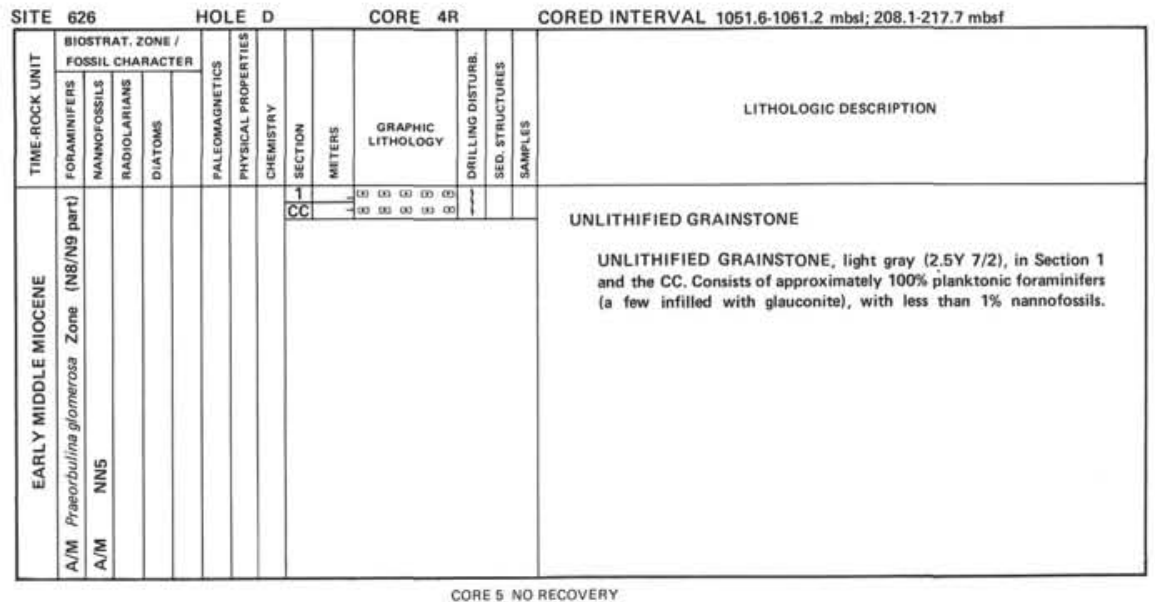

CORE 5 NO RECOVERY

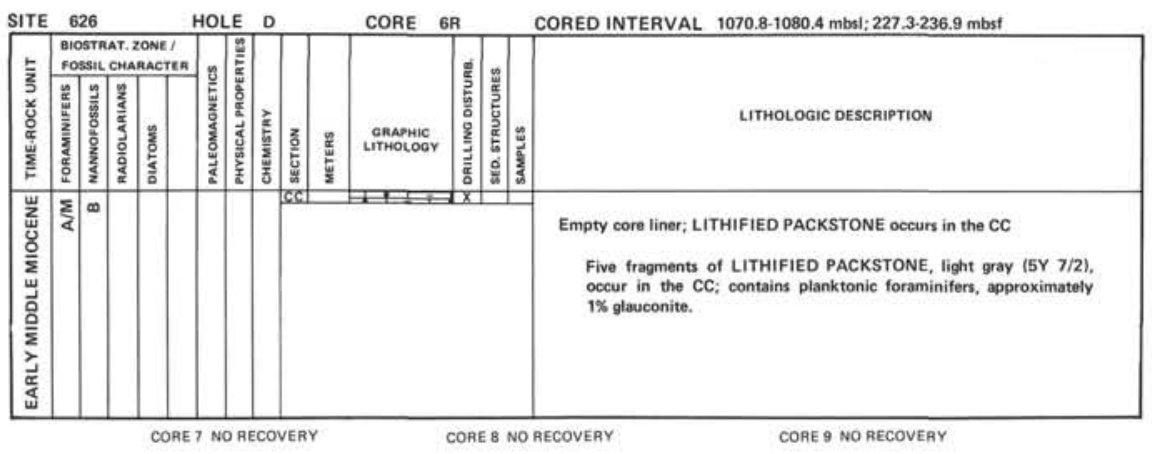

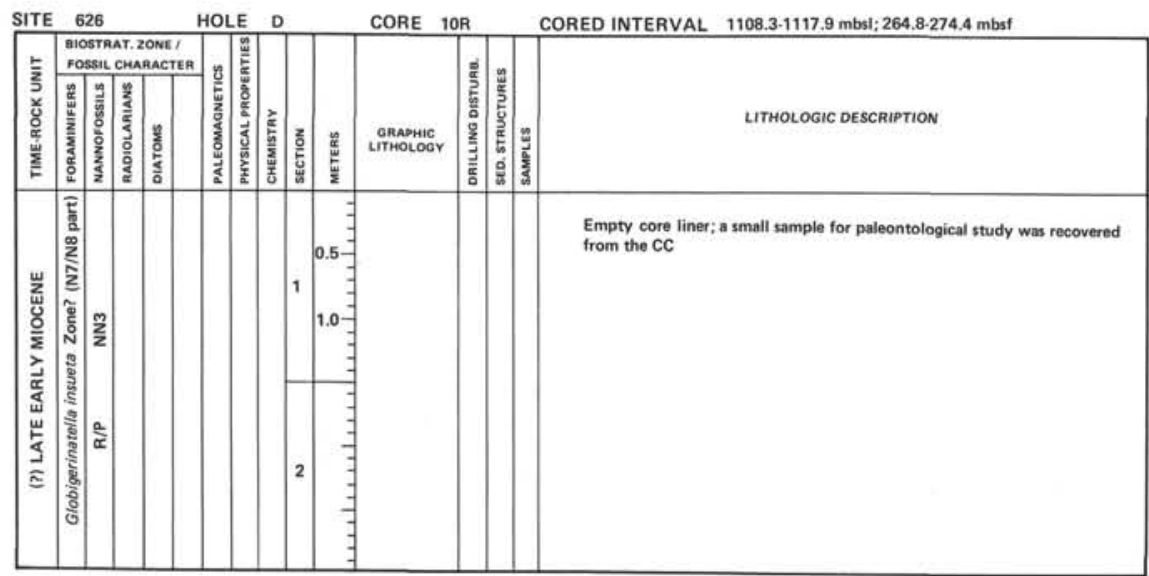



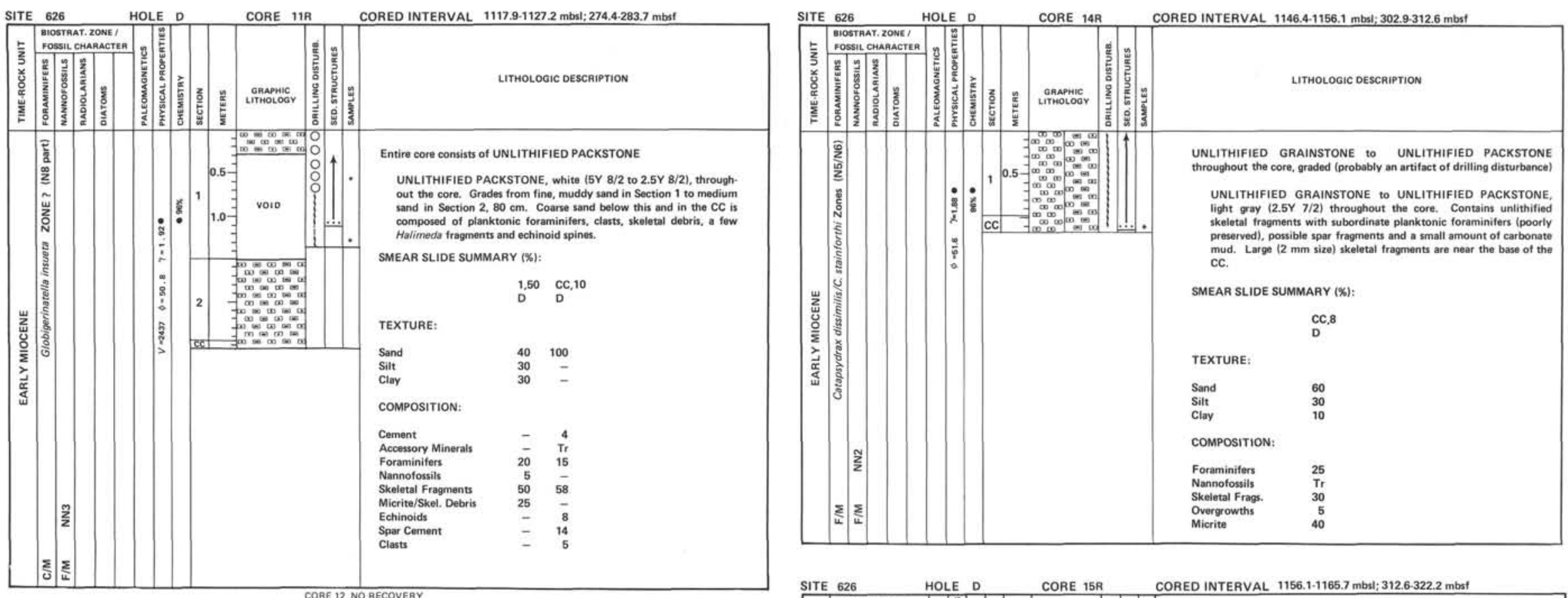

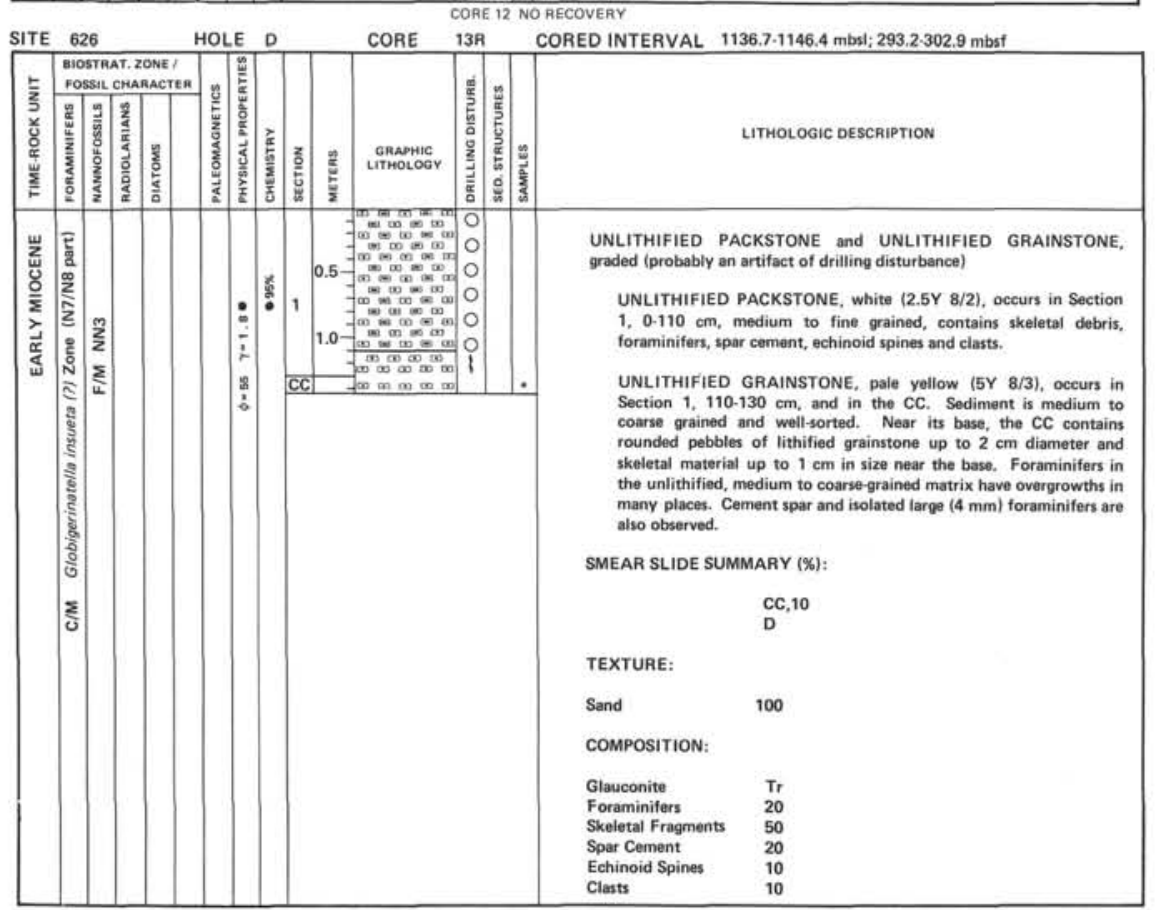
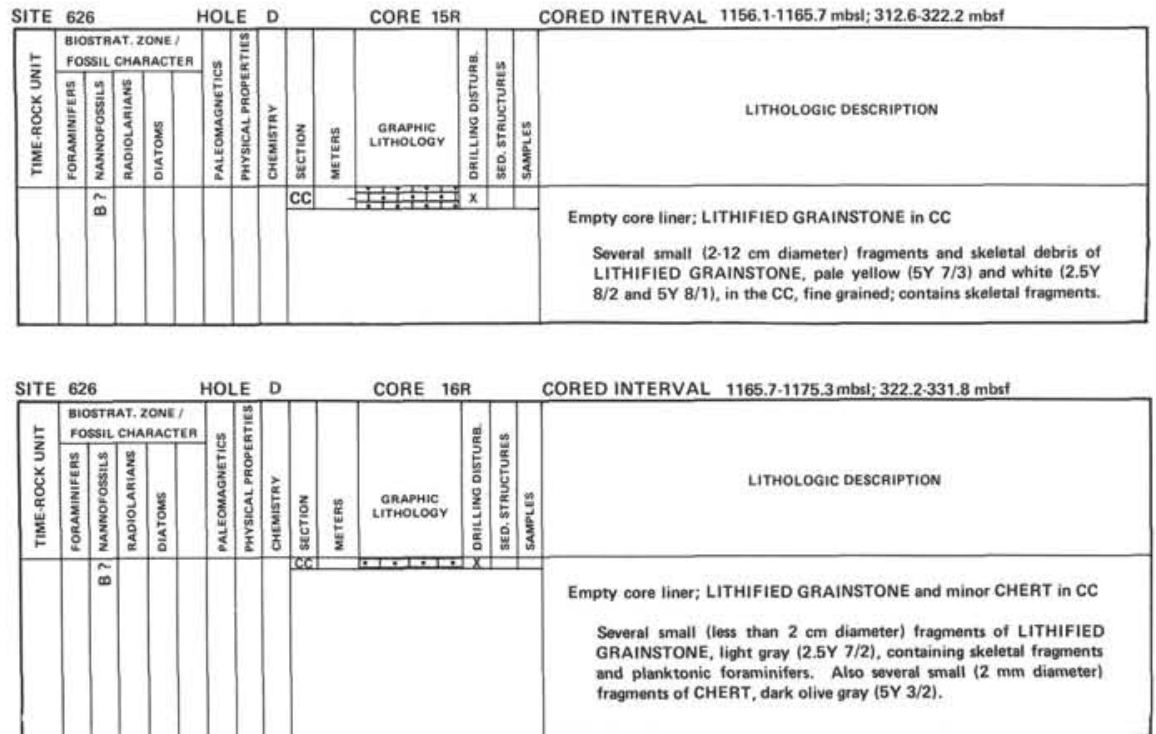

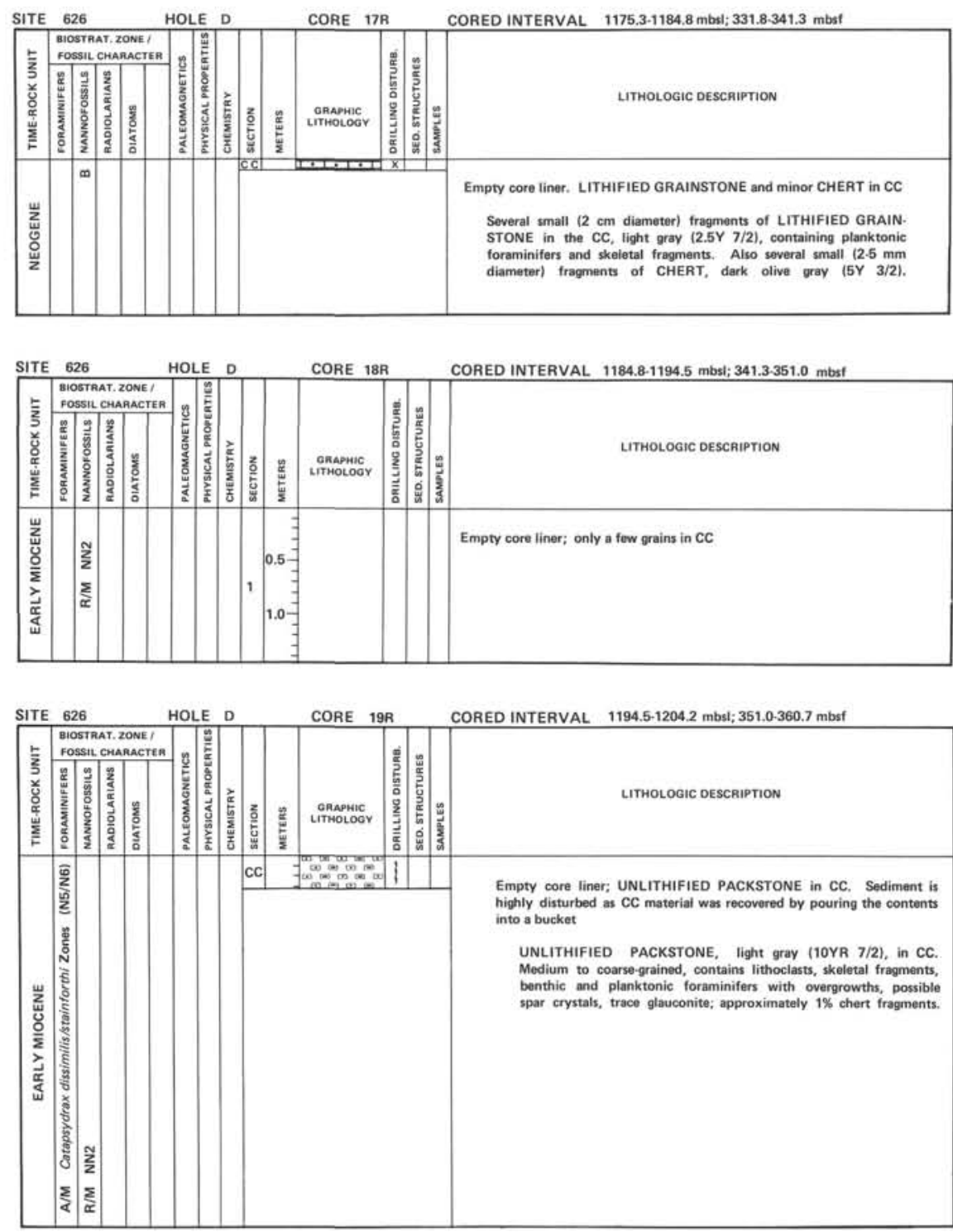

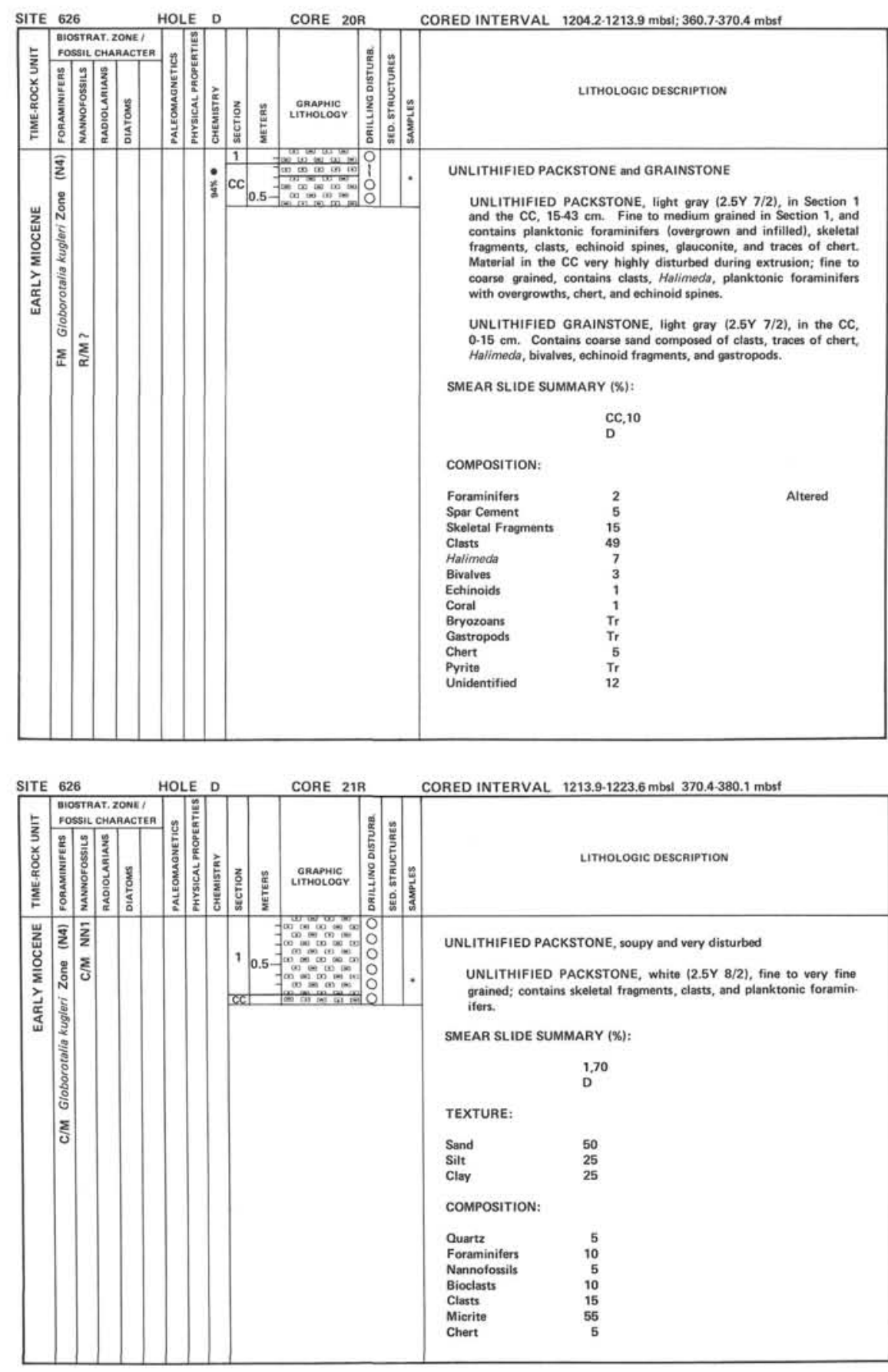




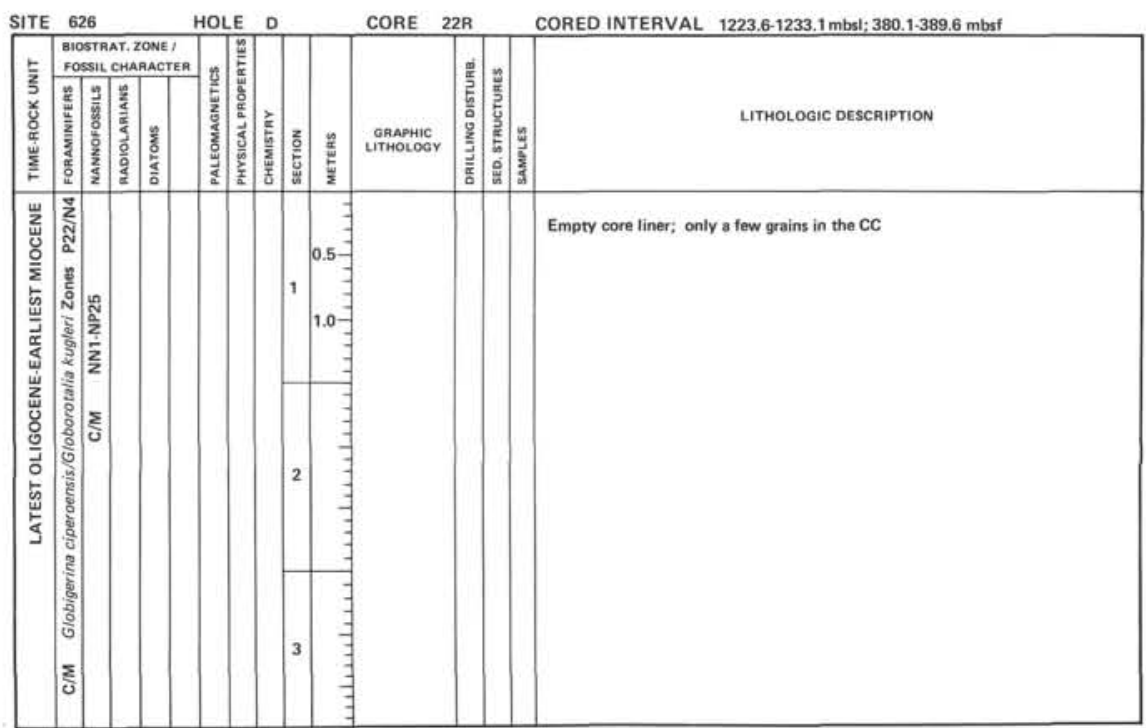

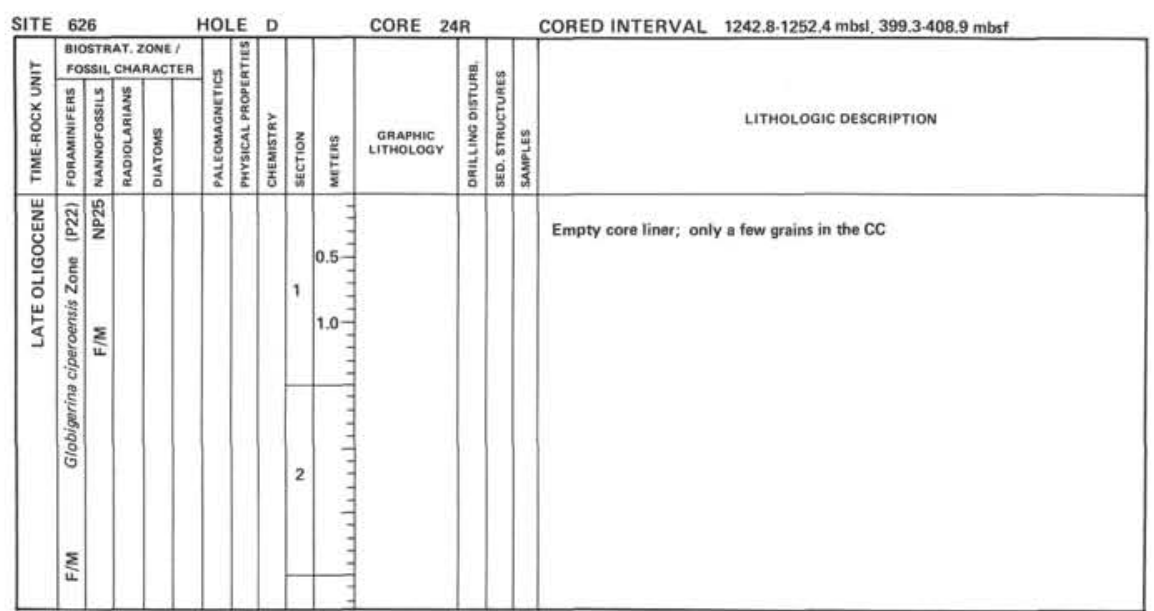

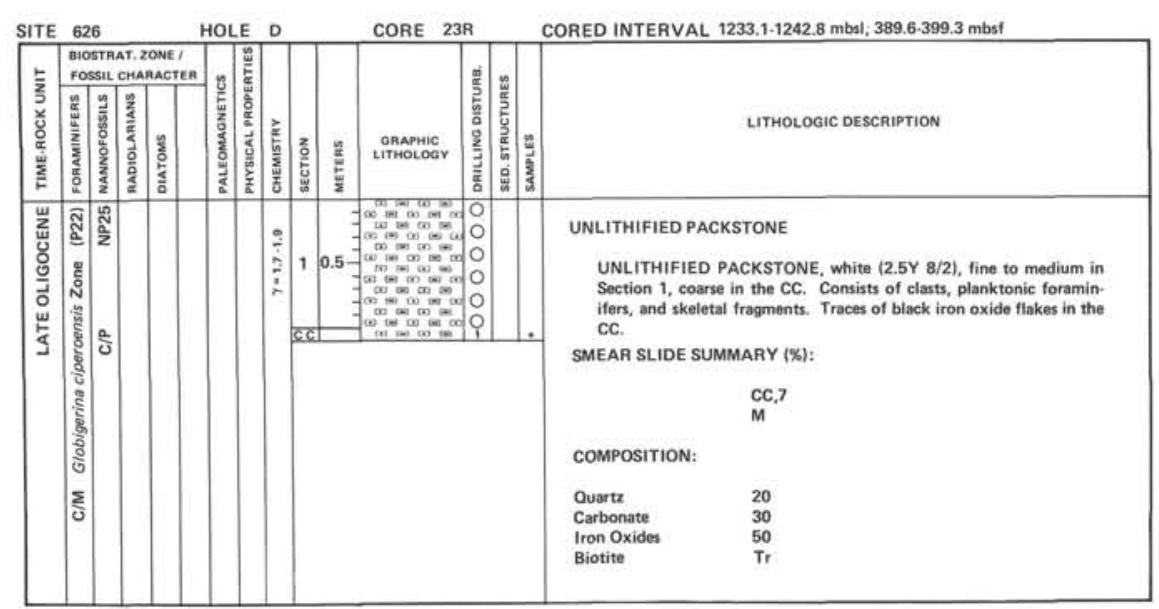

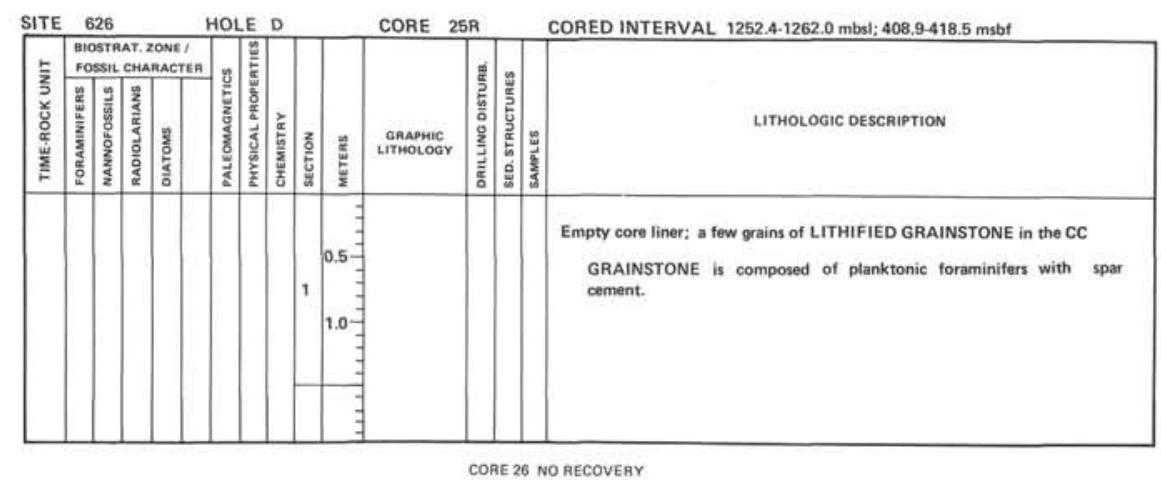




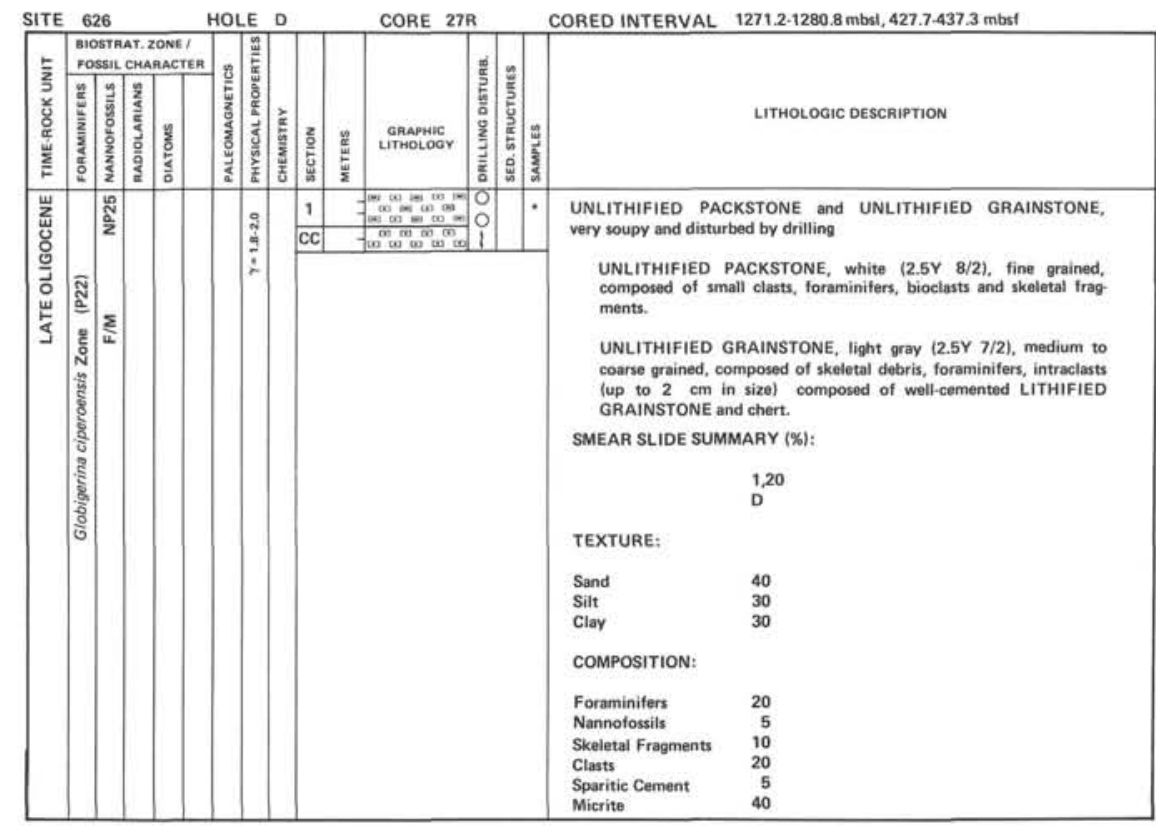

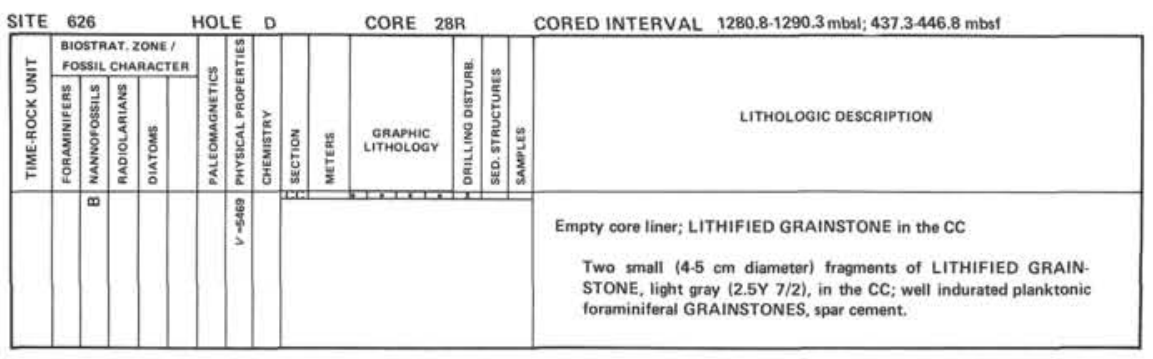


SITE 626 (HOLE A)

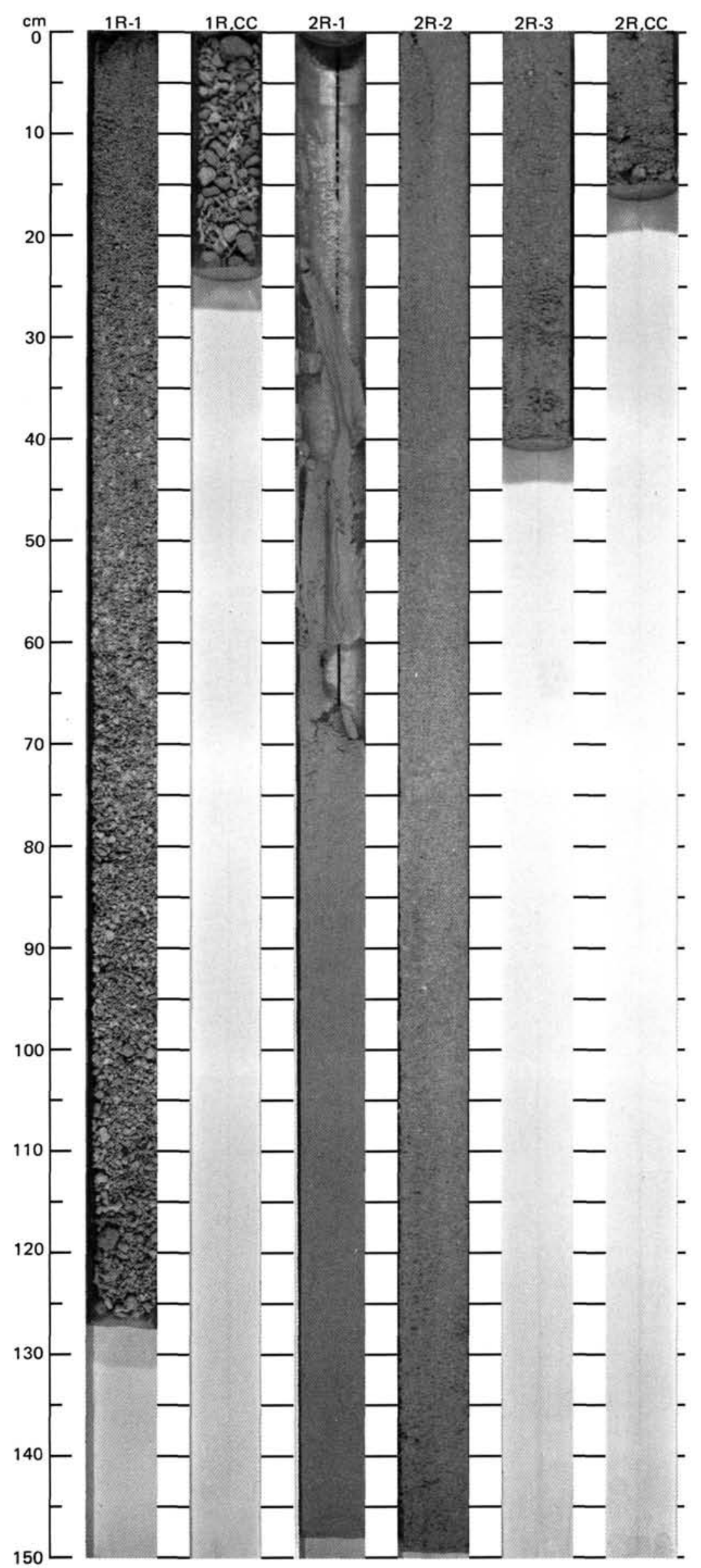


SITE 626 (HOLE B)

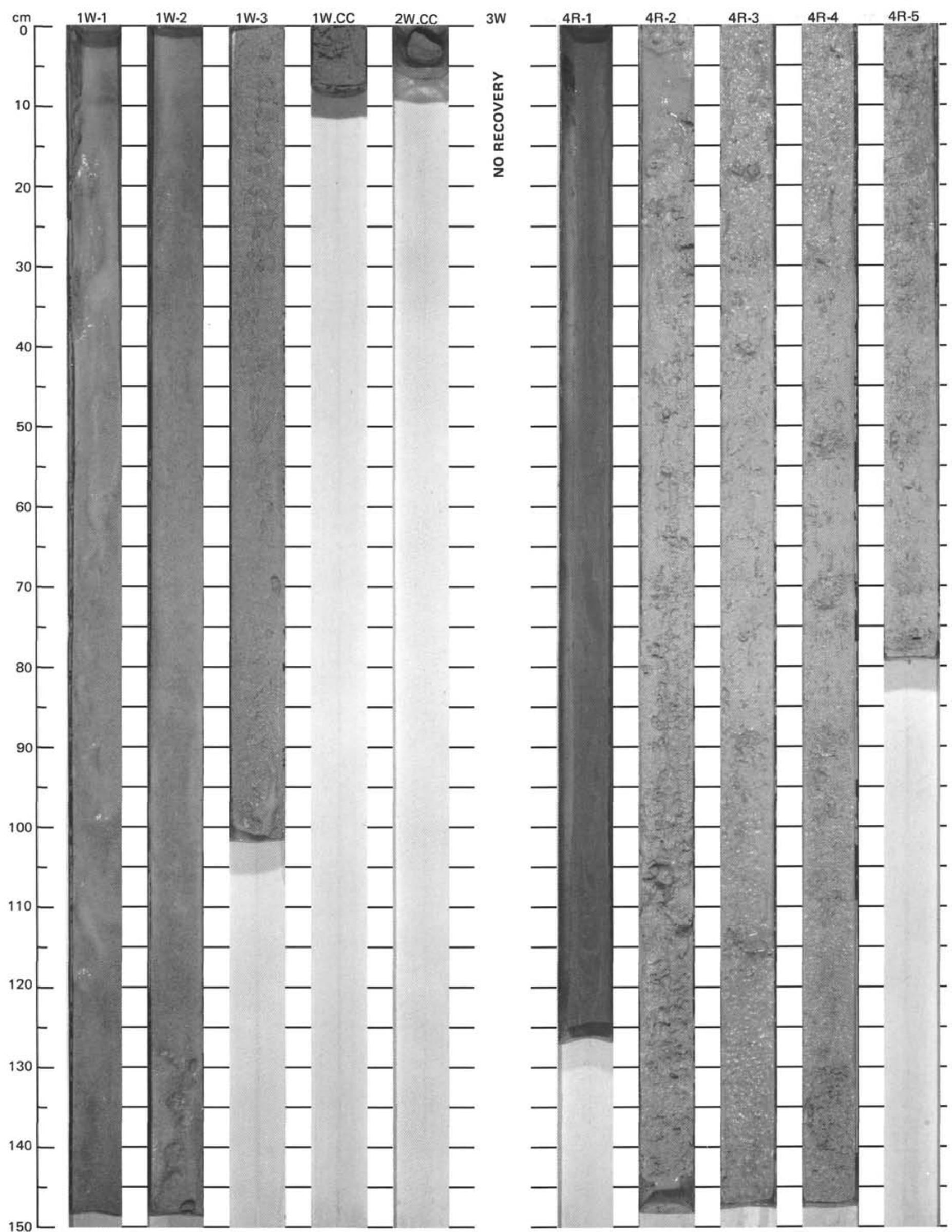


SITE 626 (HOLE B)

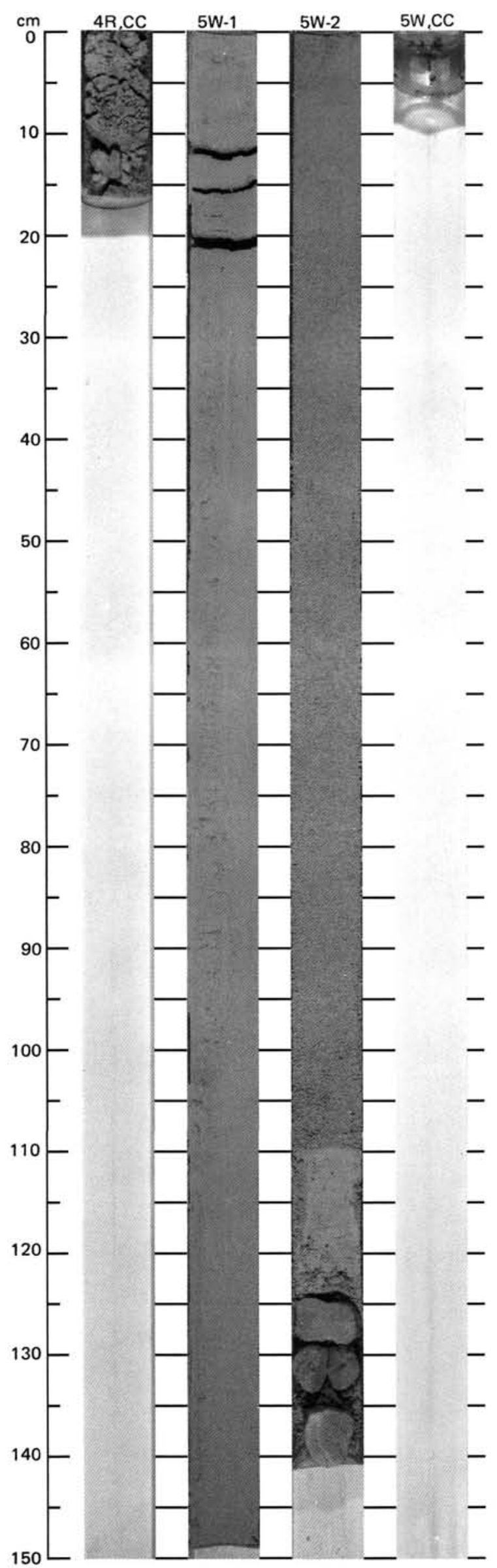


SITE 626 (HOLE C)

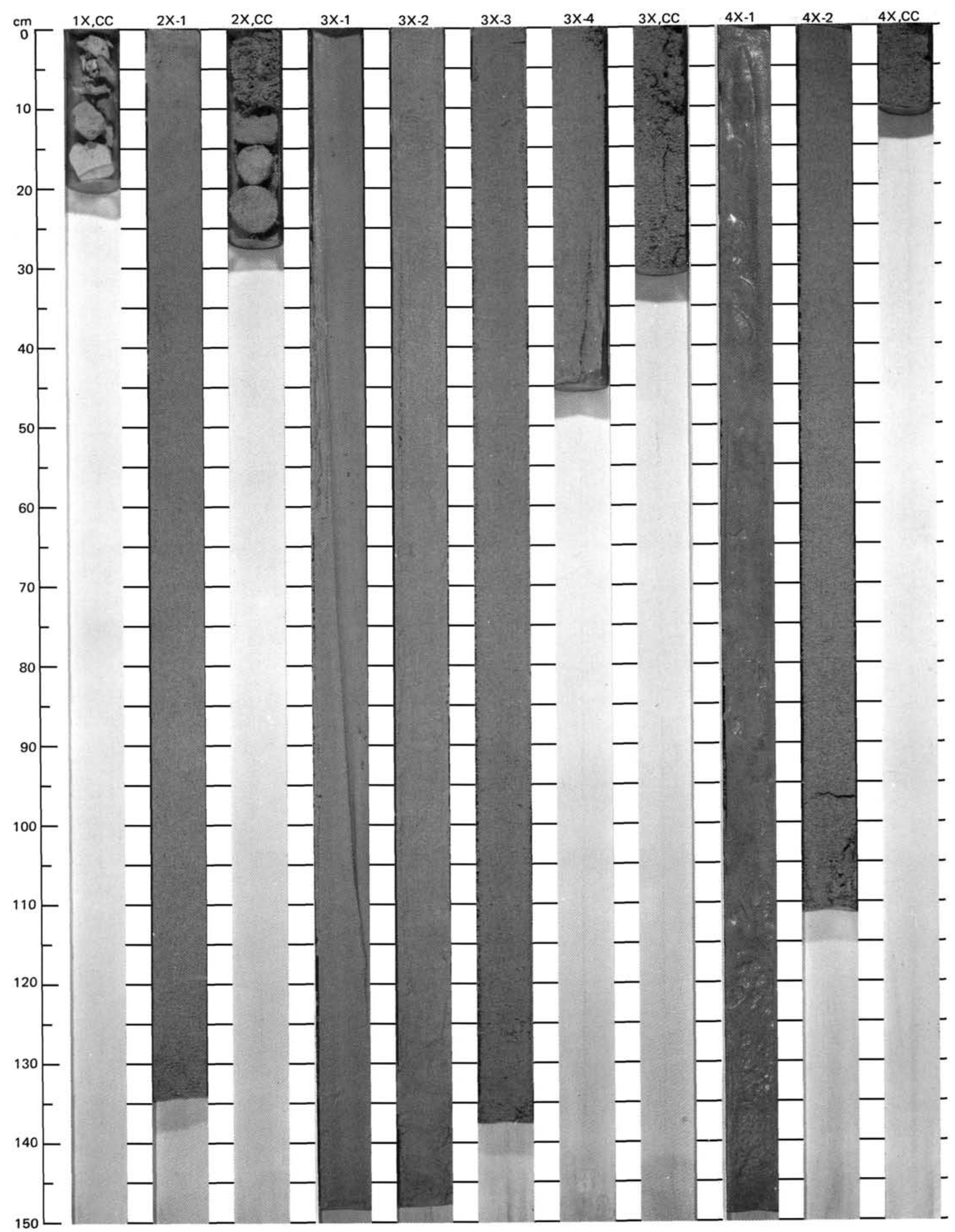


SITE 626 (HOLE C)

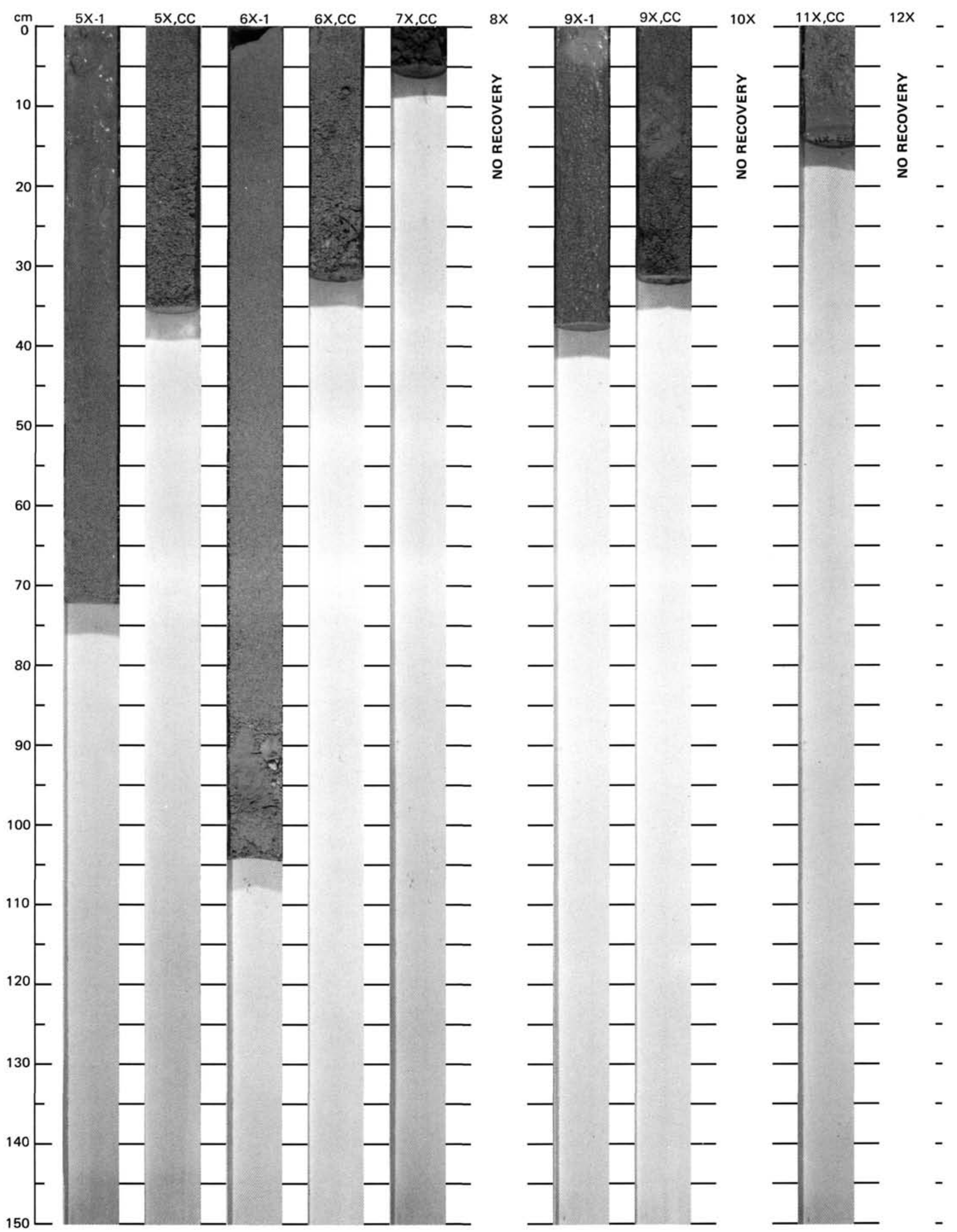


SITE 626 (HOLE C)

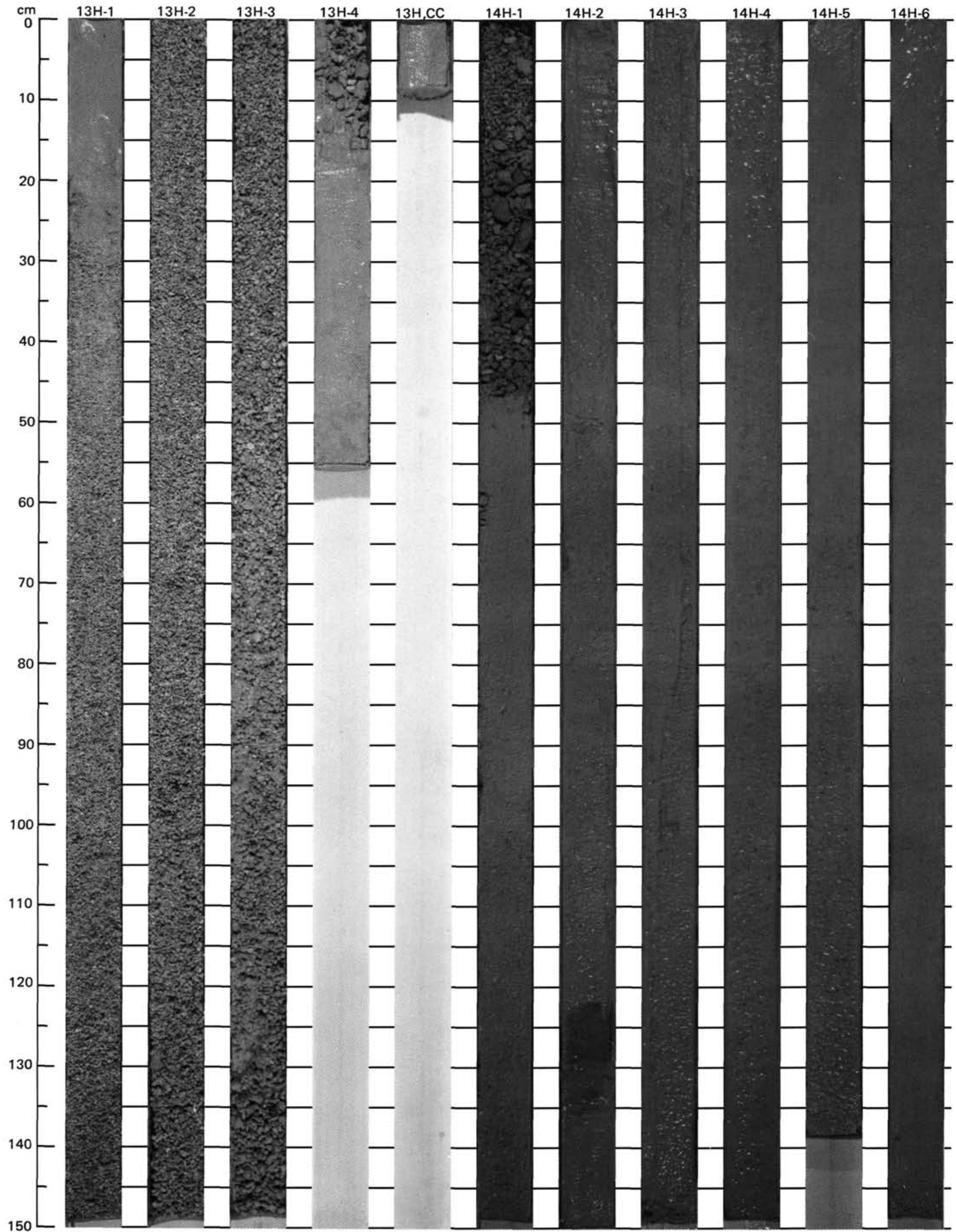


SITE 626 (HOLE C)

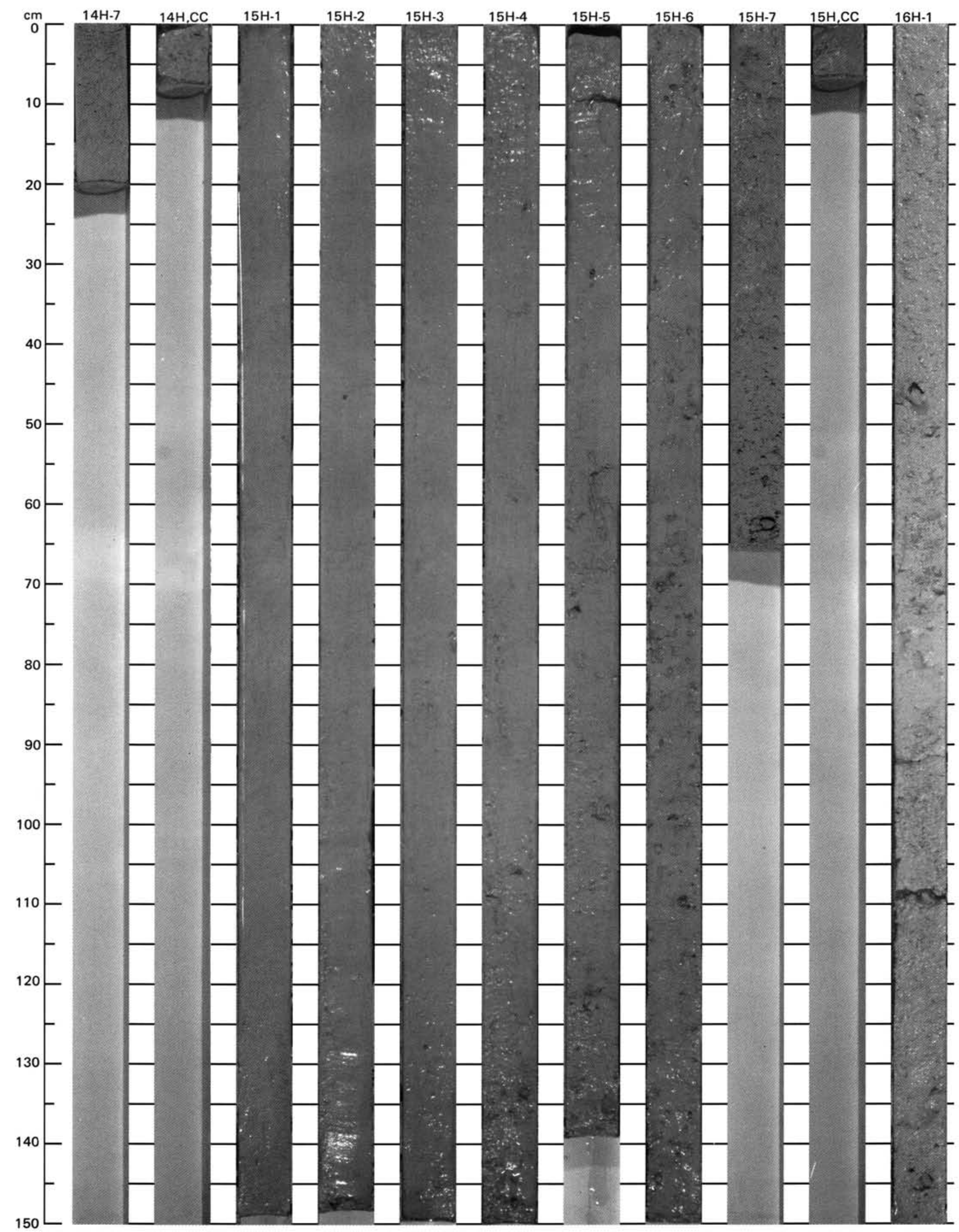


SITE 626 (HOLE C)

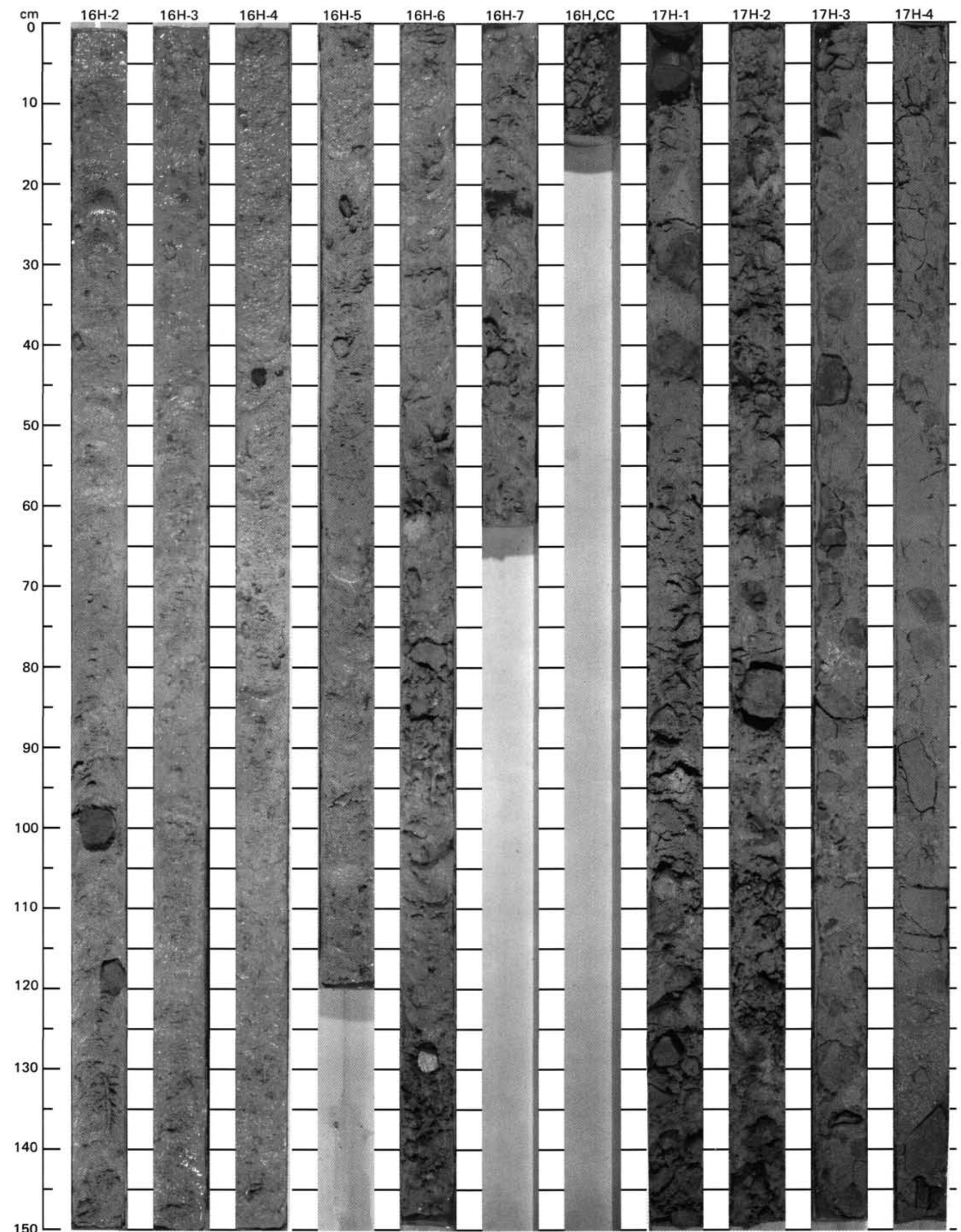




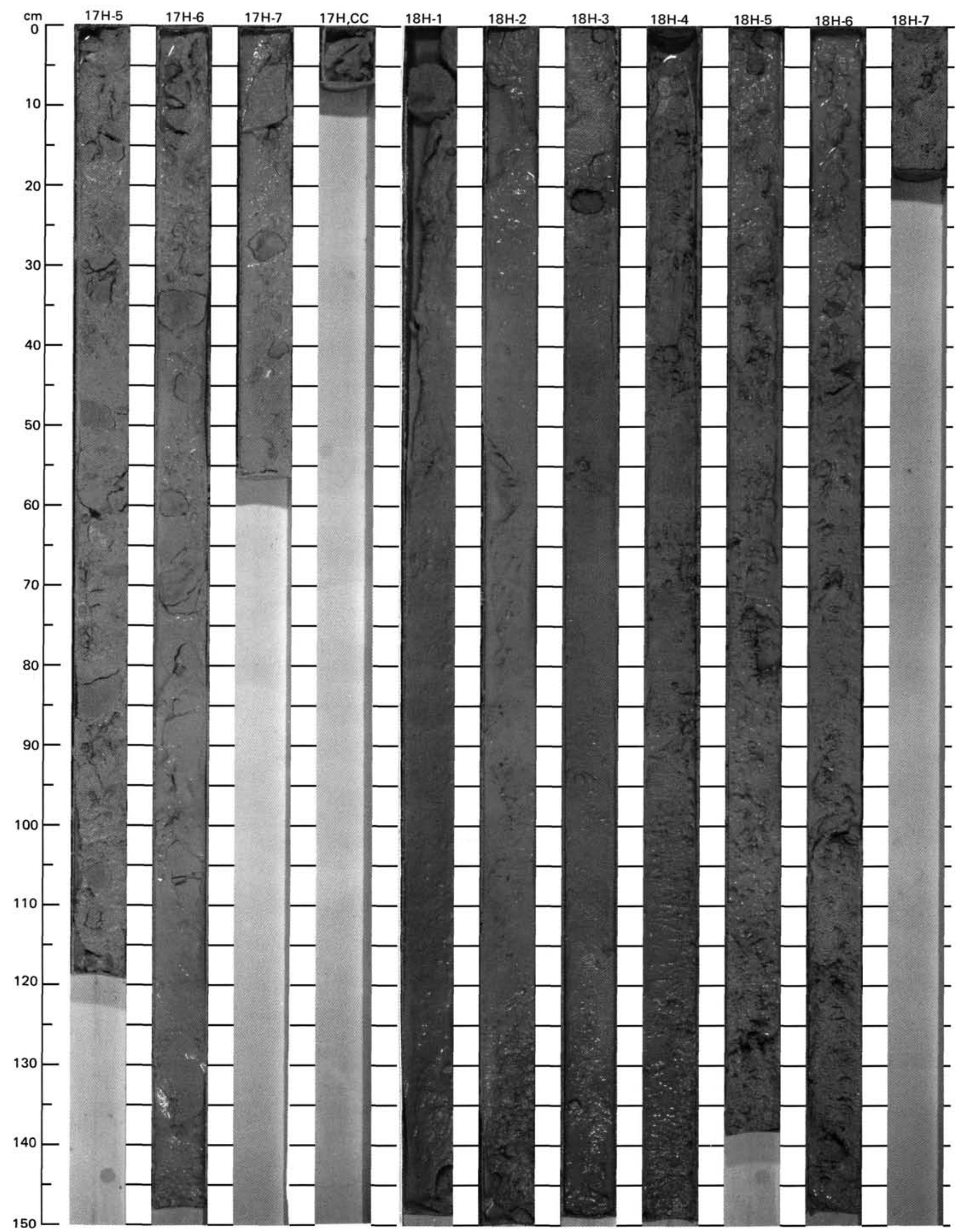




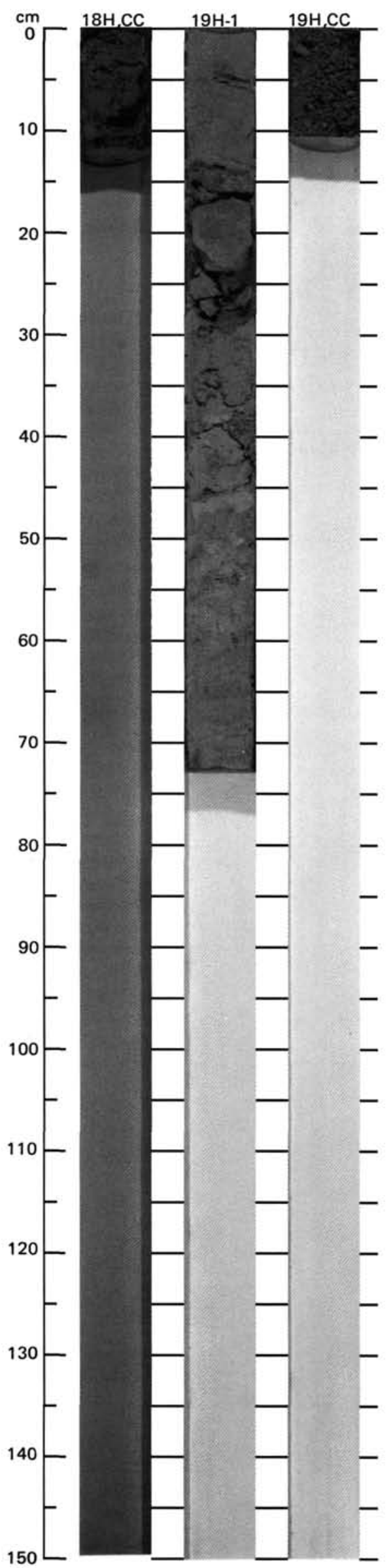


SITE 626 (HOLE D)

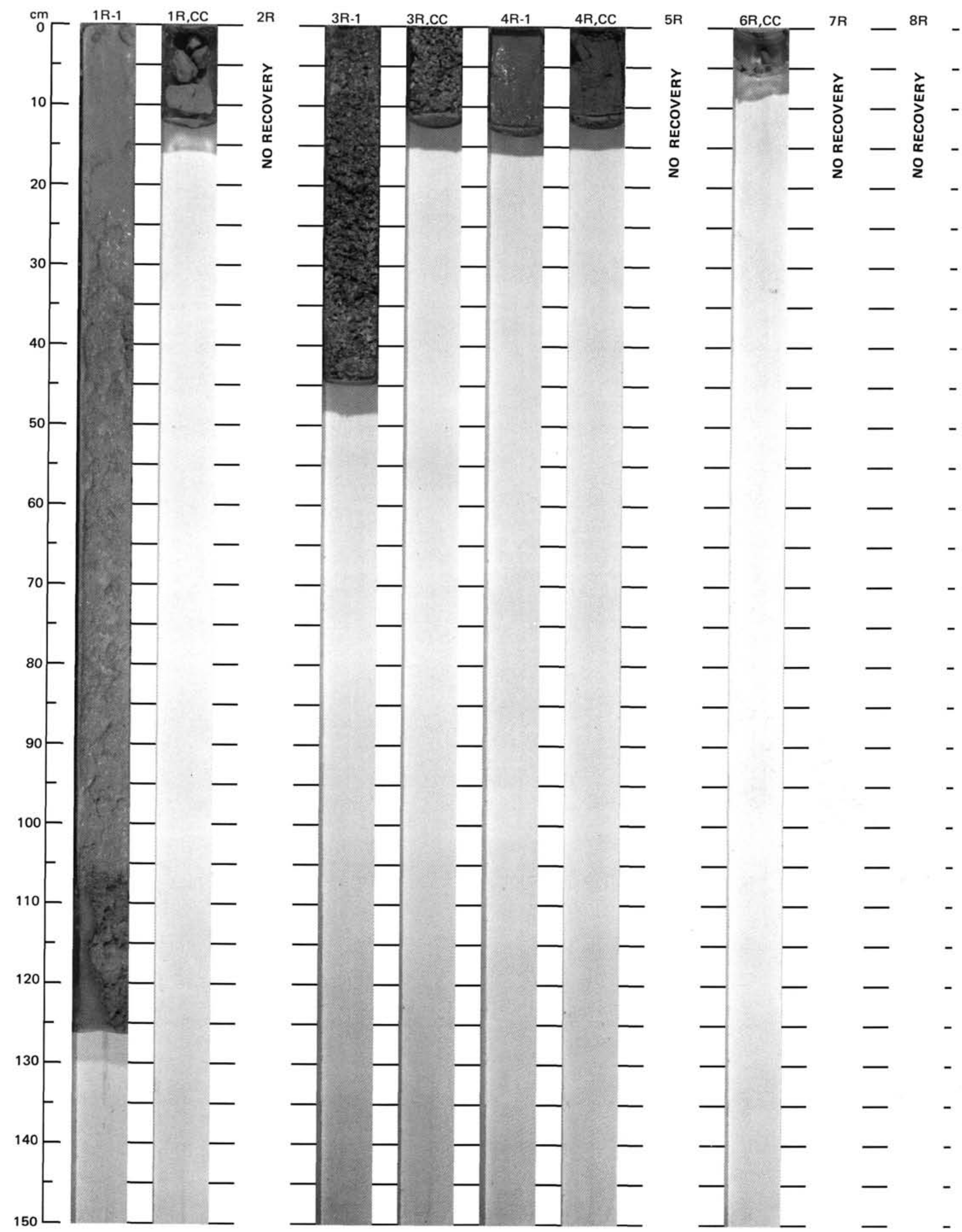


SITE 626 (HOLE D)

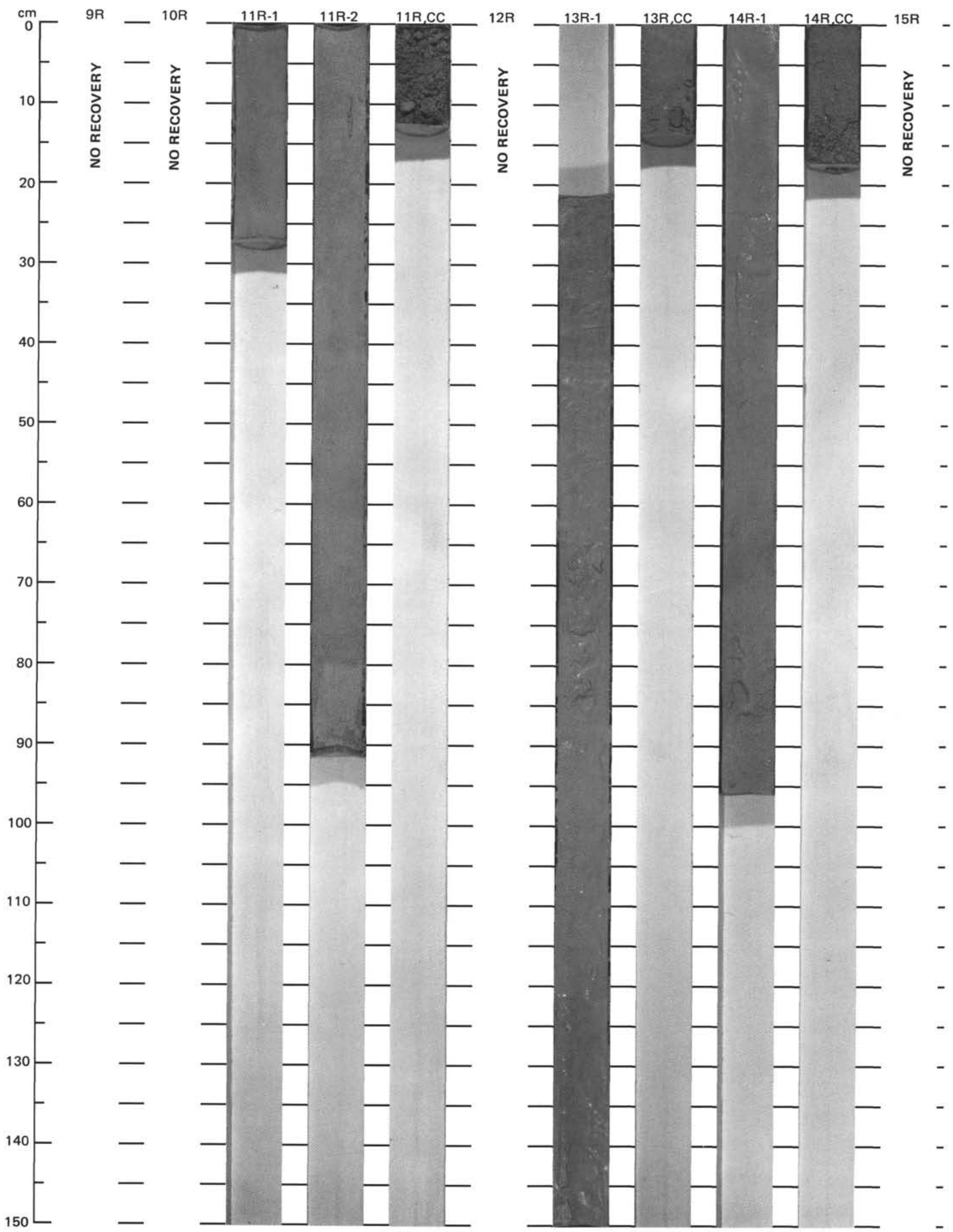


SITE 626 (HOLE D)

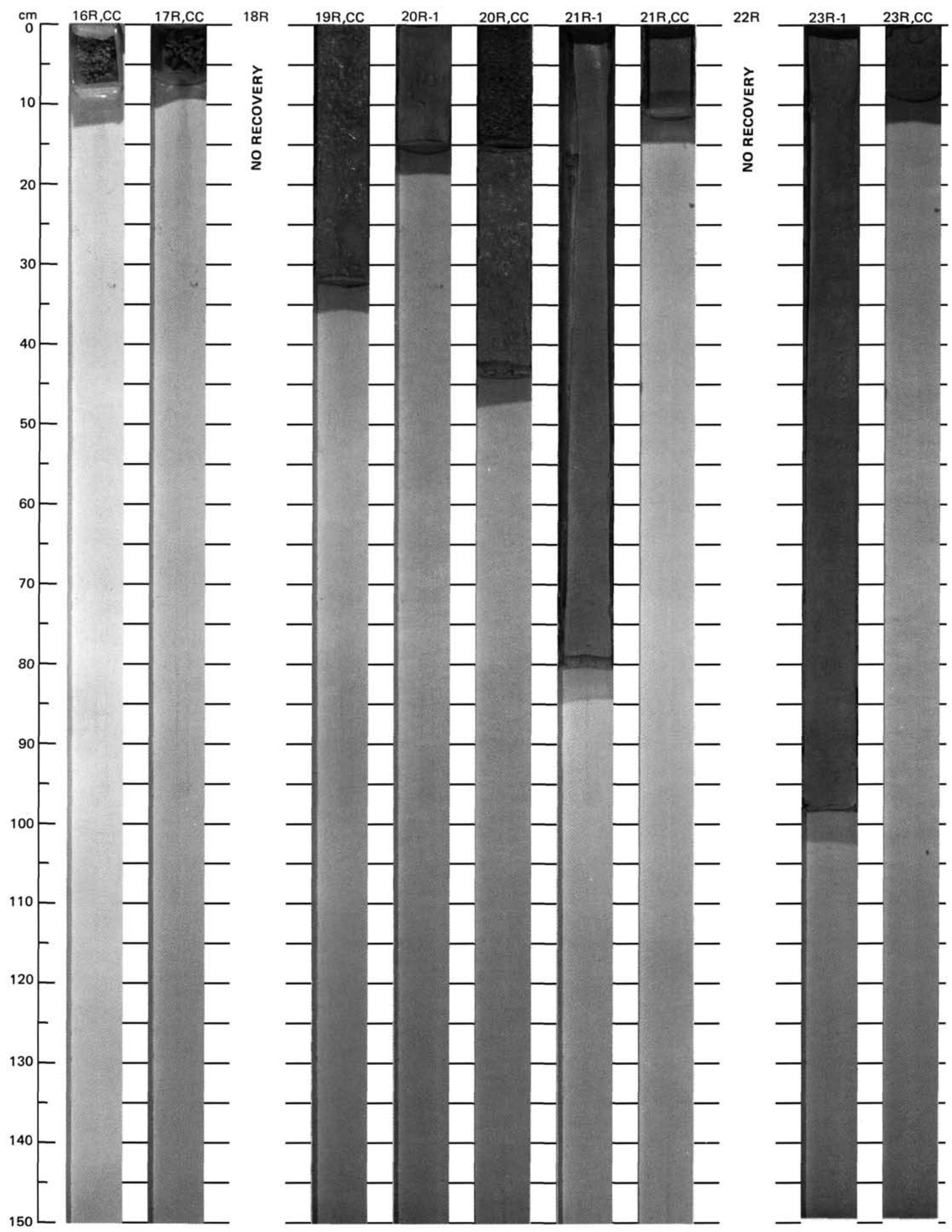




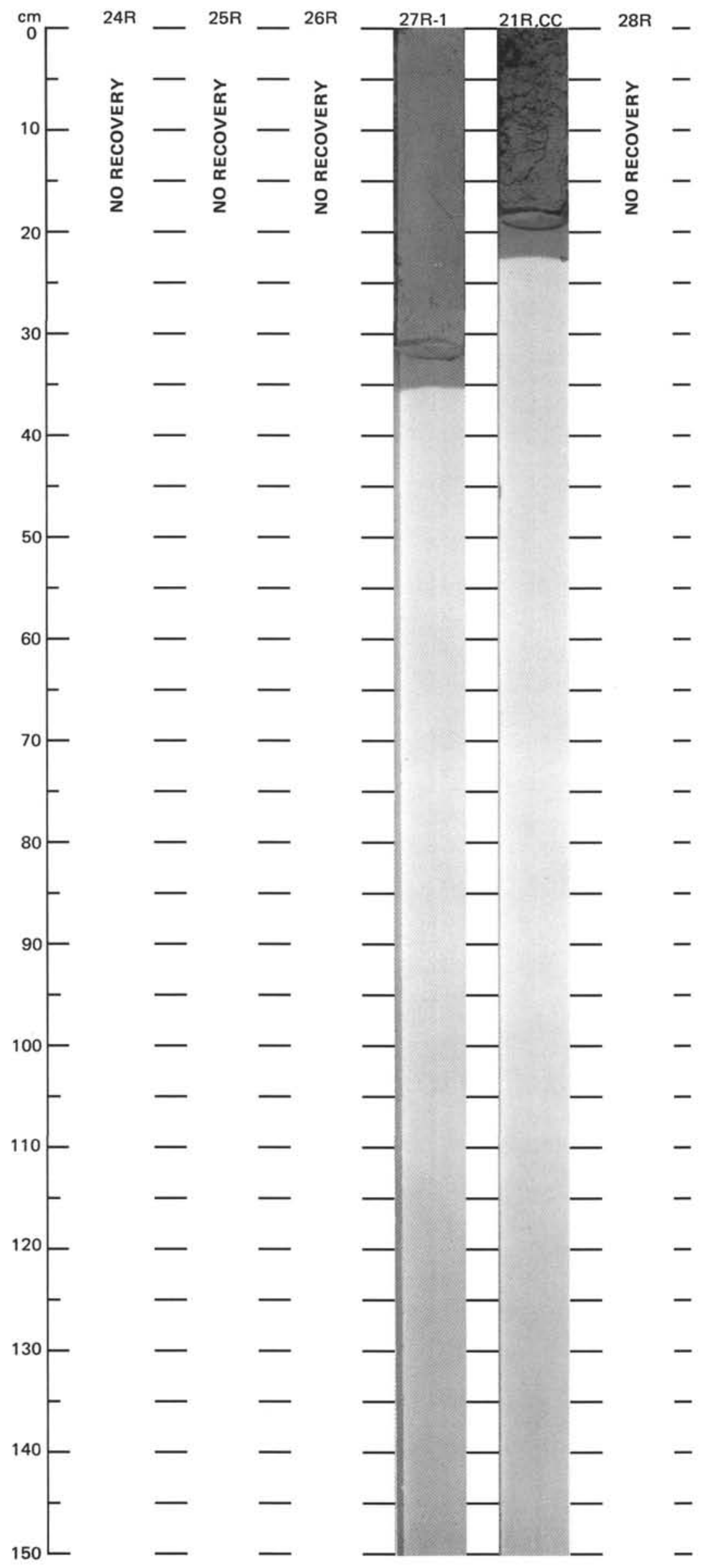

